\title{
Article
}

\section{Architecture as Crime Control}

\author{
Neal Kumar Katyal ${ }^{\dagger}$
}

\section{CONTENTS}

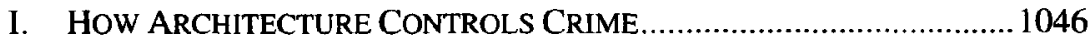

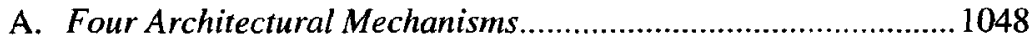

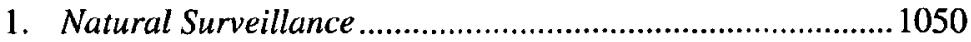

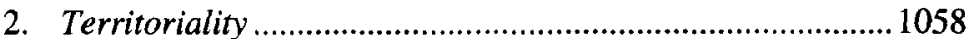

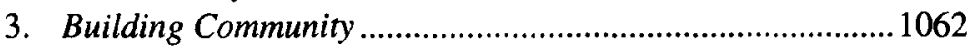

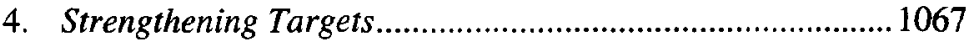

B. Four Constraints on Crime .......................................................1071

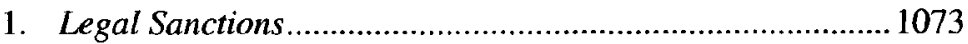

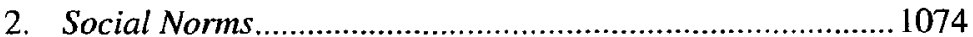

a. Looking Through Broken Windows...............................1078

b. Architecture as Social Expression.................................1083

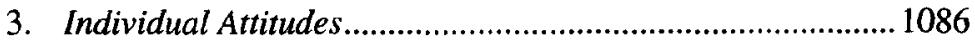

4. Perpetration Cost .......................................................... 1089

II. METHODS FOR THE GOVERNMENT TO HARNESS ARCHITECTURE ... 1090

A. Government as Builder........................................................... 1092

1. Housing......................................................................... 1092

$\dagger$ Visiting Professor, Yale Law School (2001-2002); Professor of Law, Georgetown University Law Center. Thanks to workshops at Georgetown, Yale, Fordham, University of Virginia, and University of Connecticut, and to Bruce Ackerman, Allie Alperovich, Akhil Amar, Jack Balkin, Rachel Barkow, Sara Beale, Cary Bernstein, Eric Braverman, Dan Capra, Richard Chused, Andres Duany, Steven Duke, Bob Ellickson, George Fisher, Owen Fiss, Kim FordMazrui, Ryan Goodman, Karsten Harries, Julie Hilden, John Jeffries, Dan Kahan, Sonia Katyal, Don Langevoort, Roger Lewis, Raj Nayak, Dan Posner, Estelle Rosen, Jeff Rosen, Joanna Rosen, Mike Seidman, Nikhil Shanbhag, Kate Stith, Lynn Stout, and Emily Talen.

1039

Imaged with the Permission of Yale Law Journal 
2. Public Lands 1095

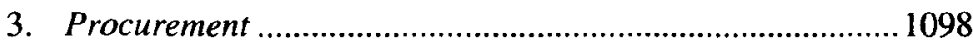

B. Government as Regulator......................................................1100

1. Crime Impact Statements ..................................................1101

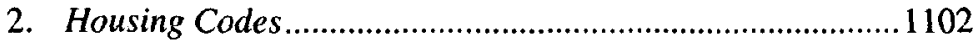

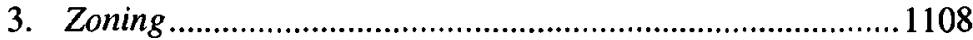

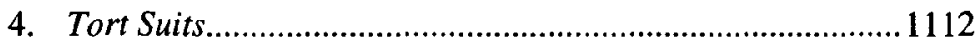

5. Contractual Regulation ....................................................116

C. Government as Enforcer ...........................................................1119

1. Regulation of Places of Crime ..........................................1119

2. Criminal Regulation of Owners of Places ............................1122

3. Criminal Regulation of Perpetrators and Others ................1123

a. Crimes Against Neighbors and Networks .....................1123

b. Crimes Against Architecture ......................................1124

c. Law Enforcement Priorities ........................................1125

4. Community Policing ………..............................................1126

III. SOME RISKS OF ARCHITECTURE ……........................................1127

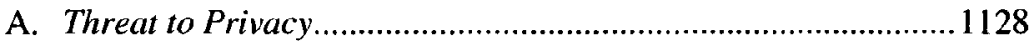

B. Social Control …................................................................1130

C. Geographic Substitution..........................................................1133

D. Suboptimal Architecture ..........................................................1135

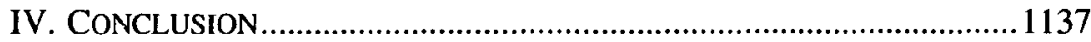

Imaged with the Permission of Yale Law Journal 
At the beginning of the twenty-first century, one of the most important and underexplored forms of crime control is architecture. Building on work in architectural theory, this Article demonstrates how additional attention to cities, neighborhoods, and individual buildings can reduce criminal activity. In so doing, it considers as "architecture" the full range of activities, from building design to city planning, with which architects are concerned.

Understanding the relationship between crime and architecture is especially important as it becomes increasingly clear that conventional law enforcement methods are, at best, partially effective in the fight against crime. Over the past century, advances in architecture have far outpaced those in law; from cranes to bulldozers, plastics to steel, we have developed sophisticated tools and machines to shape the topography of the land. Rather than following longstanding precedent, architecture has often stressed innovation and has been subject to market forces that promote better and cheaper designs.

This Article seeks to provide an account of effective crime control that focuses more on architecture and less on conventional methods of law enforcement. "An ounce of prevention is worth a pound of cure." Architectural solutions can prove more practical than the utopian ideas often considered when crime control gets interdisciplinary, e.g., better parenting and families and stronger law enforcement (from the political right), or more jobs and education (from the political left). These projects, though worthwhile, are often difficult to accomplish. Architectural improvements that control crime, in contrast, can be adopted and implemented locally with real effect. The idea is not to spend more money-a major impediment to the solutions described above - but to spend it differently.

Many civilizations have used design to reinforce particular belief systems. ${ }^{2}$ Indeed, a standard notion in the emerging field of cyberlaw, associated most directly with Lawrence Lessig, is that the "architecture" of the Internet can prevent crime. A focus on architecture might seem to make unique sense for the Internet: As Lessig observes, the Internet, an artificial

1. [Benjamin Franklin], PA. GAZETTE, Jan. 28-Feb. 4, 1735, at 1 (discussing fire prevention). Lady Wootton has also argued strongly in favor of prevention of crime rather than punishment down the road. BARBARA WOOTTON, CRIME AND THE CRIMINAL LAW 91-118 (1963); see also MODEL PENAL CODE $\$ 1.02$ (1962) (stating that the Code's primary purpose is "to forbid and prevent" criminal acts and that the purpose of sentencing is "to prevent the commission of offenses"). This move, away from treating crime after it happens and toward a view of preventing crime before it happens, is one familiar to doctors, who often weigh the benefits of preventive medicine against the costs of treatment. E.g., David L. Sackett et al., Evidence-Based Medicine: What It Is and What It Isn't, 312 BRIT. MED. J. 71 (1996).

2. WLLIAM H. ITTELSON ET AL., AN INTRODUCTON TO ENVIRONMENTAL PSYCHOLOGY 1 (1974); Lawrence J. Vale, ARChiteCture, POWER, AND NATIONAl IDENTITY 3 (1992) ("Throughout history and across the globe, architecture and urban design have been manipulated in the service of politics."). 
environment, is all architecture (or code) and thus infinitely malleable, at least in theory. ${ }^{3}$ Yet the real world may be more amenable to architectural constraints than the Internet. Architectural changes are far more enduring than code, which can be hacked instantaneously with potentially permanent effects. Once the code is cracked, information can be disseminated across the globe and becomes infinitely copyable. Thus, while the real world does not consist only of architecture, it can be subject to more lasting architectural solutions than cyberspace. It is time to reverse-engineer cyberlaw's insights, and to assess methodically whether changes to the architecture of our streets and buildings can reduce criminal activity.

Outside of cyberlaw, contemporary legal scholars and government have not given sufficient attention to architecture, instead thinking primarily about the effect of legal sanctions on crime, and only incidentally about how other social institutions affect crime. In recent years, the discussion has evolved to consider the impact of perpetration cost (the monetary price of engaging in a particular crime) and the role of social norms. ${ }^{4}$ An examination of architecture can supplement this progress, suggesting, for example, that the high crime rates of inner cities are related to the physical environment and not simply to the conventional explanations (poverty, unemployment, poor schools, and the like).

Yet the instinctive reaction of many lawyers is to focus on legal rules, without thinking about the constraint of physical space. Ironically, even an architectural problem in crime control- "broken windows"-has encouraged legal, not architectural, solutions. James Wilson and George Kelling's classic article argued that physical signs of disorder-typified by the broken window-prompt further crimes. ${ }^{5}$ Accordingly, governments across the country have stepped up law enforcement and prosecution of minor offenses like vandalism in an attempt to deter these "gateway" crimes, crimes that are harbingers of more serious ones. A focus on architecture opens up other possibilities, from shatterproof windows to subtle barriers that make windows less accessible. Indeed, the very program on which Wilson and Kelling based their article, the New Jersey Safe Neighborhoods Act, used design-based strategies, but they went unmentioned in the article, which had a strictly legal focus.

3. See LAWRENCE LesSIG, CODE 4-14 (1999); Neal Kumar Katyal, Criminal Law in Cyberspace, 149 U. PA. L. REv. 1003, 1009-10, 1038-39 (2001) (discussing architectural solutions to computer crime). Some economists refer to these types of constraints as "technical." RICHARD G. LIPSEY \& PETER O. STEINER, ECONOMICS 855-56 (4th ed. 1975).

4. See Dan M. Kahan, Social Meaning and the Economic Analysis of Crime, 27 J. LEGAL STUD. 609, 610-22 (1998) (discussing social norms and crime); Neal Kumar Katyal, Deterrence's Difficulty, 95 MICH. L. REV. 2385, 2447-62 (1997) (same); id. at 2416-19, 2434-41 (outlining perpetration-cost strategies); Katyal, supra note 3, at 1010-11, 1039-42 (same).

5. James Q. Wilson \& George L. Kelling, Broken Windows: The Police and Neighborhood Safety, ATLANTIC MONTHLY, Mar. 1982, at 29. 
This Article begins by exploring architectural solutions to crime and then suggests ways for the government to take a more active role in architectural design. Part I considers four architectural concepts: increasing an area's natural surveillance (its visibility and susceptibility to monitoring by private citizens), introducing territoriality (by demarcating private and semiprivate spaces), reducing social isolation, and protecting potential targets. The remaining Section of Part I explores how the practical application of these concepts prevents crime. While architectural insights into crime prevention are applicable to almost all structures, readers will benefit by thinking of a paradigmatic application of the four concepts-a housing project in an inner city. The project is characterized by high rates of crime, distrust of police, and few opportunities for seclusion. Architectural solutions hold out much promise in this setting; unlike law enforcement, they offer many benefits and few undesirable effects. ${ }^{6}$

Drawing on extensive theoretical work about deterrence, I explain how design principles can increase the cost of perpetrating crime, facilitate law enforcement, promote development of social norms of law-abiding and lawreinforcing behavior, and shape tastes against crime. Research in architectural theory and environmental psychology reveals that architects influence, in subtle ways, the paths by which we live and think. Fast-food restaurants use hard chairs that quickly grow uncomfortable so that customers rapidly turn over; elevator designers place the numerals and floor indicator lights over people's heads so that they avoid eye contact and feel less crowded; supermarkets have narrow aisles so that customers cannot easily talk to each other and must focus on the products instead. ${ }^{7}$ With

6. Of course, when crime rates are low and law enforcement is working, crime prevention through architecture might be unnecessary or even unwise, and this point counsels caution in applying architectural solutions in legislation across the board. Just as law enforcement has veered toward adopting the same coercive tactics against every criminal, whether a speeding mother or a murderer, e.g., Atwater v. City of Lago Vista, 121 S. Ct. 1536, 1549-51 (2001) (dismissing a Fourth Amendment suit against a police officer who handcuffed and arrested a mother for failure to wear a seatbelt, threw her into a squad car-one without seatbelts-in front of her children, and brought her to the police station), solutions based on architecture also run the risk of ignoring important differences between settings. Not all forms of architecture are created equal, and some types of architectural prevention may have deleterious effects.

7. ITTELSON ET AL., supra note 2, at 346 (discussing fast-food restaurants); FRANCIS T. MCANDREW, ENVIRONMENTAL PSYCHOLOGY 109 (1993) (discussing elevators); ROBERT SOMMER, SOCIAL DESIGN $42-45$ (1983) [hereinafter SOMMER, SOCIAL DESIGN] (discussing supermarkets); see also ROBERT SOMMER, PERSONAL SPACE 121 (1969) [hereinafter SOMMER, PERSONAL SPACE] (providing other examples, such as a cafe that hired an architect to design a chair that placed "disagreeable pressure upon the spine if occupied for over a few minutes" and Conrad Hilton's decision to move couches out of hotel lobbies to minimize the number of lingering visitors).

Products, too, can prevent crime. For example, the government can cither punish drunk drivers after the fact, or it can try to design cars with automatic breathalyzers built into their ignition systems. It can punish speeders for going substantially above the speed limit, or it can prevent the construction of cars that go above a certain speed. This Article concentrates on changes to the architecture of real property, not to the design of personal property. Many of the 
strategies like these, private architects are currently engaging in social control. Law occasionally harnesses the power of physical space to shape social norms and uses architecture as an expressive tool to embody certain commitments. The platform ramps required by the Americans with Disabilities Act, for example, not only allow access for the disabled, but also express societal beliefs about discrimination. ${ }^{8}$

Part II illustrates specific legal mechanisms that facilitate design-based solutions to crime. Distinguishing among situations where the government acts as a builder, those where it acts as a civil regulator, and those where it acts as a criminal enforcer, the Article finds solutions in a variety of legal fields. When the government builds housing, designs streets, and maintains parks, attention to architecture can prevent crime. Many housing projects have acted as invitations to crime; government procurement regulations can favor structures that act as invitations to community. Attention by government can also lead to greater awareness of design-based solutions in the private sector.

Private precautions can also be stimulated directly through government regulation. For example, if private actors are ignoring crime prevention through architecture, a jurisdiction might require crime impact statements before significant housing and commercial developments are built. Zoning decisions and building codes could also be modified to incorporate principles of architectural design and crime prevention. Tort suits can similarly encourage landlords and developers to adopt more effective design, and these lawsuits can harness the educative power of insurance companies. In the field of contracts, the law governing lease agreements could be modified to require landlords to disclose poor architectural features and local crime rates to prospective tenants. In the field of criminal law, laws against breaking and entering can be used to protect architecture directly. Governments can also use nuisance and forfeiture to take over abandoned buildings and other places where crime festers.

Part III considers some of the problems that arise when governments employ architecture to prevent crime. Architectural strategies can call for the creation of extended panopticons, raising the major problem that Michel Foucault identified with Jeremy Bentham's ideal-an expansion of social

same considerations apply, however, and substantial evidence suggests that product design can deter crime. For example, the use of caller-ID has been shown to reduce the incidence of harassing phone calls. See Ronald V. Clarke, Deterring Obscene Phone Callers: Preliminary Results of the New Jersey Experience, I SECURITY J. 143 (1990). Other evidence suggests that providing potential victims with alarms that notify the police about domestic violence will reduce future aggression. See Graham Farrell \& Ken PEASE, OnCe BITTEn, Twice BITten: RePEat Victimisation and Its Implications for CRime Prevention (Home Office Police Dep't, London, Crime Prevention Unit Series Paper No. 46, 1993).

8. See JAMES G. SCOTT, ARChITECTURAL BuILDING CODES 227-96 (1997) (describing Americans with Disabilities Act provisions that regulate architecture). 
control into all aspects of life. These strategies may also threaten privacy by opening up spaces to greater public view. Another looming problem concerns the possible displacement of crime to areas without good design. These objections are weighty, and there are unique risks to using architecture as a crime-control method. Understanding the power of architecture can inform society's resolution of how much and what type of privacy and social control we want, particularly when those wants weigh against the effective prevention of crime. Society will inevitably make architectural choices; much is gained by folding these choices into a deliberate and transparent legal strategy.

At the outset, I talk a lot about architecture and only a little about law. This may be odd for a law review article, but the design is intentional. Focusing on architecture first permits a fuller understanding of how architectural variables influence human behavior. That understanding, in turn, informs decisions about how law can best use architecture. The Article shows how many of our current laws and regulations governing housing and city planning, in fields that are thought of as entirely separate from criminal law (such as property, torts, and contracts), can be effectively harnessed to prevent crime. Architectural considerations should be integrated into law, not banished into a separate and isolated discipline.

Such integration will underscore a number of theories of American law that are applicable to architecture. Consider, for example, three prominent claims in law today: (1) Government can never be "neutral," for its inaction is tantamount to its action; ${ }^{9}(2)$ law does not simply change the "price" of behavior; it shapes tastes because preferences are endogenous; ${ }^{10}$ and (3) legal solutions that neglect community understandings and social norms are bound to fail." Architecture has analogues to each claim: (1) There is no form of neutral architecture, for any choice of architecture is bound to have externalities that favor certain groups in society; (2) the design of buildings can shape attitudes and desires; and (3) architecture that ignores aspects of community is likely to have a destructive effect. This inquiry into architecture and crime also helps us understand how architectural considerations can supplement other areas of law, such as torts (specifically, preventing catastrophic accidents through better design) and criminal procedure (particularly, informing the question of what types of places are most likely to engender a reasonable expectation of privacy). ${ }^{12}$

9. JOSEPH RAZ, THE MORALITY OF FREEDOM 120-23 (1986).

10. See, e.g., Mark Kelman, A Guide to Critical Legal Studies 126-41 (1987); Samuel Bowles, Endogenous Preferences: The Cultural Consequences of Markets and Other Economic Institutions, 36 J. ECON. LITERATURE 75, 78-81 (1998).

11. See generally ROBERT C. ELLICKSON, ORDER WiTHOUT LAW (1991) (arguing that social norms, not law, constrain much human behavior). 
As a result of this synthesis of law and architecture, not only will we look at law in new ways, we will look at physical space differently, too. The lens of expressivist and social norms theories of criminal law will generate new understandings of architecture and push architects to become more interdisciplinary as well.

Architecture by itself cannot stop crime, nor can it replace law. Architectural determinism is dead, for good reason. Nevertheless, its death should not blind us to the many subtle and important ways in which architecture alters human behavior, in crime as well as in other areas. Especially in a world of heterogeneous offenders, government must draw upon all constraints on crime - law, cost, norms, and architecture - to have maximum impact.

\section{How ARChITECTURE CONTROLS CRIME}

Law enforcement is necessary and important, but even with substantial improvements, it will not fully succeed in crime prevention. Society lacks resources to invest in enough prosecutors, police, jails, juries, and judges, and additional expenditures will receive diminishing returns. Moreover, even at current rates of enforcement, complaints of civil rights violations, false arrests, incompetent police officers, and malicious prosecutors plague the system. ${ }^{13}$ Police do not learn about most crimes: Only a little more than one-third are even reported. ${ }^{14}$ Statistics show that law enforcement is only able to solve one-fifth of all reported crimes. ${ }^{15}$ Prisons are notoriously bad at rehabilitating criminals and sometimes serve as "schools for crime" that promote criminal activity. ${ }^{16}$

12. See William J. Stuntz, The Distribution of Fourth Amendment Privacy, 67 GEO. WASH L. REV. 1265, 1265-70 (1999) (observing how jurisprudential protection for privacy depends on the type of physical space).

13. As Wilson says, "[I]n crime prevention, not too much should be expected of the police." James Q. Wilson, Dilemmas of Police Administration, 28 PUB. ADMIN. REV. 407, 415 (1968); see also THOMAS A. REPPETTO, RESIDENTIAL CRIME 71 (1974) ("Altering the environment in which a criminal operates will likely prove a simpler matter than altering the behavior of individual criminals or the forces which produce criminal populations.").

14. U.S. DEP'T OF Justice, Criminal Victimization In THE United States 1999, at 96 tbl.91 (2001), at http://www.ojp.usdoj.gov/bjs/pub/pdf/cvus99.pdf (estimating that 36.3\% of crimes are reported).

15. Fed. Bureau of Investigation, U.S. Dep't of Justice, Crime in the United STATES 1999, at 6 (2000) (finding a twenty-one percent clearance rate). Even for the most serious crime-murder-three to four out of ten cases remain unsolved. See Hearing Before the Subcomm. on Oversight of Gov't Mgmt. of the Senate Comm. on Governmental Affairs, Restructuring and the Dist. of Columbia, 106th Cong. (2001), http://www.wpdc.org/News/2001/ 0103/010322_statement.htm (statement of Charles H. Ramsey, Chief of Police, Washington, D.C., Metropolitan Police Department).

16. See Richard Lowell Nygaard, Is Prison an Appropriate Response to Crime?, 40 ST. LOUIS U. L.J. 677 (1996). 
Traditional law enforcement, however, is not the only possible solution. Architects have suggested that crime can be prevented by manipulating the design and placement of many simple items, such as doors, bus stops, and park benches. Today's airports prevent crime by replacing bathroom entrance doors with right-angle entrances that permit the warning sounds of crime to travel more freely and that reduce the sense of isolation. ${ }^{17}$ Countries throughout the world, such as Australia, Canada, Great Britain, Japan, and the Netherlands have used architectural design techniques to prevent crime. ${ }^{18}$ The 2000 Sydney Olympics self-consciously employed architecture to reduce crime by modifying landscapes, restricting access to sites, changing parking patterns, and creating visibility around stadiums. ${ }^{19}$

Unfortunately, for the past six decades, American criminal law has focused on the specific characteristics of offenders (such as economic status, race, age, employment status, and mobility) and has largely ignored the location of crime. ${ }^{20}$ But just as individuals can be recidivists, so too can certain places. ${ }^{21}$ In Minneapolis, for example, three percent of locations are responsible for fifty percent of calls to which police respond, and similar patterns occur in other cities. ${ }^{22}$ Such findings come as no surprise to many Americans, who think in terms of "safe" and "unsafe" areas. Nor are they

17. SOMMER, SOCIAL DESIGN, supra note 7, at 45-49.

18. Timothy Crowe, Crime Prevention through Environmental Design 8 (2000). Britain has a "Safe Neighbourhoods Unit" that surveys and makes improvements to lighting and physical safety. The Mayans used zigzag walls around their residences as mechanisms to deter intruders, and medieval European cities were built on top of mountains to take advantage of the natural terrain and to repel invasion. $1 d$. at 83,212 .

19. Police declared planning for the games to be "the single biggest crime prevention project ever undertaken" in Australia. Paul McKinnon, Olympics 2000, at http://www.aic.gov.au/ conferences/urban/mckinnon.pdf (last visited Nov, 29, 2001).

20. This focus stands in contrast to earlier studies of criminals, most notably those from the University of Chicago in the first half of the century. See ROBERT PARK ET AL., THE CITY (1925) (suggesting that social interaction or its lack is facilitated by particular forms of architecture in cities and that social organization can have an impact on crime rates); Louis Wirth, Urbanism as a Way of Life, 44 AM. J. Soc. 1, 15-16 (1938) (making a similar argument). These studies tracked nineteenth-century French and English criminology, which concentrated on the place of crime as well. E.g., M.A. QUETElet, A TREATISE ON MAN (New York, Burt Franklin 1842); John Glyde, Localities of Crime in Suffolk, 19 J. STAT. SOC'Y LONDON 102 (1856).

21. See Michael E. Buerger et al., Defining the "Hot Spots of Crime": Operationalizing Theoretical Concepts for Field Research, in CRIME AND PLACE 237, 238-40 (John E. Eck \& David Weisburd eds., 1995); Tracey L. Meares, Norms, Legitimacy and Law Enforcement, 79 OR. L. REV. 391, $391(2000)$ (arguing that "the structural and cultural organization of neighborhoods can either facilitate or hinder crime occurrence"); Lawrence W. Sherman et al., Hot Spots of Predatory Crime: Routine Activities and the Criminology of Place, 27 CRIMINOLOGY 27 (1989); see also William J. Wilson, Studying Inner-City Social Dislocations: The Challenge of Public Agenda Research, 56 AM. SOC. REV. 1, 10-11 (1991) (discussing concentration of crime in inner cities).

22. Lawrence W. Sherman, Hot Spots of Crime and Criminal Careers of Places, in CRIME AND PLACE, supra note 21, at 35, 36. Studies of cities such as Houston and Akron support this finding. See C. RAY JEFFERY. CRIME PREYENTION THROUGH ENVIRONMENTAL DESIGN 195 (rev. ed. 1977); see also WESLEY G. SKOGAN, DISORDER AND DECLINE 54-55 (1990) (making a similar claim for neighborhoods in other cities). 
a surprise to police officers, who have been using pin maps for decades to plot out dangerous locations. ${ }^{23}$

It is not only in particular areas, but also in particular types of buildings, that crime is more likely. Convenience stores are often selected for robbery because they are located near major roads but tend to be too far away from the roads to be seen by passersby. ${ }^{24}$ Burglaries are much less likely in buildings where residents remain home during the day. ${ }^{25}$ And I soon discuss high-rises, which have much more crime than other buildings. ${ }^{26}$

\section{A. Four Architectural Mechanisms}

Some architects have outlined mechanisms for crime prevention through principles of design. ${ }^{27}$ This emerging field is known as "Crime Prevention Through Environmental Design" (CPTED). CPTED mechanisms are not well understood by all designers and builders. Many ignore crime prevention because their clients are wealthy enough to afford special protection, from burglar alarms to doorpersons. ${ }^{28}$ The federal government also lacks regulations for crime prevention in housing project design. ${ }^{29}$ Nevertheless, an extensive review of the architectural literature reveals four basic concepts. Design should: (1) create opportunities for natural surveillance by residents, neighbors, and bystanders; (2) instill a sense of territoriality so that residents develop proprietary attitudes and

23. J. Thomas McEwen \& Faye S. Taxman, Applications of Computer Mapping to Police Operations, in CRIME AND PLACE, supra note 21, at 259, 260.

24. Michael R. GOTTFREDSON \& TRAVIS HIRSCHI, A GeNERAL TheORY OF CRIME 17-18 (1990); JEFFERY, supra note 22, at 205; Dennis C. Duffala, Convenience Stores, Armed Robbery, and Physical Environmental Features, 20 AM. BEHAV. SCI. 227 (1976).

25. REPPETTO, supra note 13 , at $48-49$.

26. OSCAR NEWMAN, DEFENSIBLE SPACE 191 (1972) (stating that high-rise buildings have "seven and a half times as much vandalism, robberies, and arrests of loitering drug addicts"); infra text accompanying notcs 97-99, 200-206.

27. Schlomo angel, Discouraging Crime Through City Planning 7-15 (Ctr. for Planning \& Dev. Research, Univ. of Cal., Berkeley, Working Paper No. 75, 1968) (outlining crime prevention concepts); CROWE, supra note 18, at 36-38 (same); NEWMAN, supra note 26, at 9, 50; Stephanie W. Greenberg et al., Safety in Urban Neighborhoods: A Comparison of Physical Characteristics and Informal Territorial Control in High and Low Crime Neighborhoods, 5 POPUlation \& ENV'T 141 (1982); Roger K. Lewis, Defensive Notion: Using Environment To Ward Off Crime in Neighborhoods, WASH. POST, Sept. 7, 1996, at F1.

28. NEWMAN, supra note 26 , at 116 . Commercial architects do not generally incorporate these techniques into their design. Mary S. SMith, Crime Prevention Through ENVIRONMENTAL DESIGN IN PARKING FACILITIES (Nat'l Inst. of Justice, Research in Brief, Apr. 1996), http://www.ncjrs.org/txtfiles/cptedpkg.txt ("Many parking facilities lack CPTED design features becausu most property owners and architects are not familiar with the basic principles of design concepts for crime prevention.").

29. Interview with Lawanda Young, Policy Director, Office of the Deputy Assistant Secretary for Public and Assisted Housing Delivery, Department of Housing and Urban Development, in Washington, D.C. (June 12, 2001). 
outsiders feel deterred from entering a private space; (3) build communities and avoid social isolation; and (4) protect targets of crime.

These four goals often work in synergy so that, for example, natural surveillance is most effective when social isolation is minimized and when design delays the perpetration of crime. But the goals can conflict with each other. A theoretical and practical understanding of how each goal helps prevent crime illuminates the choice about which goals should take precedence. As the architectural literature is, generally speaking, unsystematic and soft, an interdisciplinary legal perspective can clarify the tensions and synergies among the goals.

This choice among competing goals is a small illustration of a larger point in architectural design: A one-size-fits-all approach is destined to fail. Effective prevention of crime through architecture involves working through tradeoffs among operability, aesthetics, crime prevention, and other goals. Therefore, design principles for architecture and crime control cannot be divorced from the context in which they are applied and must be malleable enough to adapt to a variety of circumstances. ${ }^{30}$ Like good police officers and prosecutors, skilled architects examine the innate functions of an existing area to see what is already working before they act. Accordingly, they recognize that effective design requires input by the community. Without such input, security features are likely to be resented, taken down, or evaded (consider the "security" doors propped open on campuses today). ${ }^{31}$ As we proceed through the four principles, they must be understood as general aims of architecture rather than concrete precepts to be applied rigidly.

30. RICHARD A. GARDINER, DESIGN FOR SAFE NEIGHBORHOOdS 55 (1978); JANE JACOBS, The DEATH AND LIFE OF GREAT AMERICAN CITIES 6, 14 (1961); Steve Kuckuk, Frank Lloyd Wright Quotes, at http://www.usonia.com/fllw.html (last visited Nov. 29, 2001) ("I never design a building before I've seen the site and met the people who will be using it.").

31. RalPh B. TAYlor \& ADELE V. HaRrell, PHYSICAl ENVIRONMENT AND CRIME 11-12 (Nat'l Inst. of Justice, Research Report, May 1996) ("[T]he crime-preventive benefits of changes in layout appear to weaken as community mobilization wanes."). For example, Bridgeport, Connecticut, erected concrete barriers near its highways to prevent individuals from driving quickly into the city to buy drugs. Police believed that the strategy would deter crime because buyers would fear "driving all over looped streets, stopping and turning around, trying to find drugs with the possibility of having their nice cars, their jewelry, their money ripped off as they look." Bridgeport Proposes Blocking Off Streets To Cut Drug Buyers, N.Y. Times, Oct. 29, 1992, at Al; see Judith Gaines, Bridgeport Erects Barriers to Drug Trade, Boston GLOBE, Nov. 15, 1992, at 45, 1992 WL 4201483; To Stop Drug Sales, Bridgeport Barricades lts Streets, N.Y. T!MEs, May 18, 1993, at B5. As a result, drug sales dropped markedly, burglaries went down from 600 per year to fewer than 100 , robberies from 300 to 25 , and the murder rate was cut in half. Rick Hampson, Crime Is Down; Barricades Too: Conn. City's Decision Has Its Critics, USA TODAY, Mar. 11, 1998, at 3A.

Bridgeport took the barriers down, however, because they were ugly and residents were not pleased with them. See id.; see also David M. Halbfinger, Bridgeport Removing Barriers That Slowed Crime but Marred Streets, N.Y. TIMES, Feb. 7, 1998, at B1 (quoting architect Oscar Newman as saying that Bridgeport implemented barriers on the cheap that "look[ed] so ugly that people turn[ed] against them"). 


\section{Natural Surveillance}

Natural surveillance refers to the use of architecture to create spaces that are easily viewed by residents, neighbors, and bystanders. The most famous exponent of this approach was Jane Jacobs, who reasoned that "eyes on the street" would deter crime. Jacobs's goal was to investigate why crime rates differed among cities. She discarded the conventional theories of architecture and crime, such as those contending that building more public housing would prevent crime. Instead, she emphasized the density and diversity of city life. ${ }^{32}$

Jacobs argued that if people could be brought out onto city streets, the crime rate would drop. She suggested, for example, that a house near a bar is much safer than one in a remote part of the countryside or city. ${ }^{33}$ The bar attracts crowds whose presence and powers of observation may deter crime and draw attention, inducing those shopkeepers and residents who live nearby to watch the activity on the street more often. The bar also has a strong profit incentive to make sure that the area is safe for its customers, and the possibility of encounters between perpetrators and members of the general public may create enough uncertainty to make planning of crimes difficult. $^{34}$

Private individuals are responsible for the majority of crime prevention. Yet much legal scholarship focuses on entities of the state, forgetting that

the public peace-the sidewalk and street peace-of cities is not kept primarily by the police, necessary as police are. It is kept primarily by an intricate, almost unconscious, network of voluntary

32. This lesson was one that great city planners such as Ebenezer Howard and Le Corbusier had ignored. JACOBS, supra note 30, at 3-5, 19-25; see also CRIME PREvENTION THROUGH HOUSING DESIGN 21 (Paul Stollard ed., 1991). Revitalizing city life is a central goal of architects today. E.g., Gottfried Boehm, Pritzker Prize to Boehm, INT'L HERALD TRIB., Apr. 18, 1986, at 20 ("I think the future of architecture does not lie so much in continuing to fill up the landscape as in bringing back life and order to our cities and towns.").

33. JACOBS, supra note 30, at 37. But see MALCOLM RAMSAY, CITY-CENTRE CRIME 25-26 (Home Office, London, Research and Planning Unit Paper No. 10, 1982) (arguing that pubs can increase crime rates); Dennis W. Roncek \& Ralph Bell, Bars, Blocks, and Crimes, 11 J. ENVTL. SYs. 35, 44 (1981) (finding that each additional bar on a residential block is correlated, on average, with four additional crimes on that block).

34. JACOBS, supra note 30, at 54; see also FlOYD J. FOWLER, JR., ET AL., REDUCING Residential CRime and Fear: The Hartford NeIGHBorhood Crime Prevention PROGRAM 2 (1979) ("Neighborhoods in which residents are out-of-doors, where surveillance is easy ... are less attractive to offenders."); Robert Hanna, Awareness, in HANDBOOK OF LOSS PREVENTION AND CRIME PREVENTION 88 (Lawrence J. Fennelly ed., 1996) (explaining that "watchers" can reduce crime).

Jacobs's observation is one instance of the great sociologist Erving Goffman's more general point that order can be created out of temporary and spontaneous social interactions. ERVING GOFFMAN, BEHAVIOR IN PUBLIC PLACES 4, 8, 243-46 (1963) [hereinafter GOFFMAN, BEHAVIOR]; ERVING GOFFMAN, INTERACTION RITUAL 1-3 (1967) [hereinafter GOFFMAN, INTERACTION RITUAL]. 
controls and standards among the people themselves, and enforced by the people themselves. In some city areas-older public housing projects and streets with very high population turnover are often conspicuous examples-the keeping of public sidewalk law and order is left almost entirely to the police and special guards. Such places are jungles. No amount of police can enforce civilization where the normal, casual enforcement of it has broken down. ${ }^{35}$

Such reasoning suggests that architecture should capitalize on publicregarding norms and encourage individuals to be involved in their communities.

Empirical studies of burglary confirm that the surveillability of an area is a major predictor of its crime rate. Crimes at universities are more likely to occur in places with poor visibility, large bushes, and no buildings across the street. ${ }^{36}$ Damage to bus seats in London is higher on upper decks of buses than on lower decks, and higher in back seats than in front ones, due to lower visibility in those locations. ${ }^{37}$ Interviews with lawbreakers reveal that "robbers are very conscious of architectural features" and that favorite locations "are the narrow and enclosed pathways where visibility is poor and witnesses nonexistent." 38

35. JACOBS, supra note 30 , at 31-32.

36. Thomas J. Molumby, Patterns of Crime in a University Housing Project, 20 AM. BEHAV. SCI. 247 (1976); see also JOHN E. CONKLIN, ROBBERY AND THE CRIMINAL JUSTICE SYSTEM 91 (1972) ("Even professionals who rob commercial establishments shield themselves from public view while in the place of business, picking a store that is set back from the street or standing in a position inside the store where they cannot be seen from outside."); CRIME PREVENTION THROUGH HOUSING DESIGN, supra note 32, at 8 (presenting an empirical study finding that targets "were chosen partly because of the potential reward they may offer and because they were not occupied, but mostly because they could be easily approached without the burglar being seen"); Richard Block \& Carolyn Rebecca Block, The Bronx and Chicago: Street Robbery in the Environs of Rapid Transit Stations, in ANALYZING CRIME PATTERNS 137, 146-48 (Victor Goldsmith et al. eds., 2000) (studying street robbery in the Bronx and Chicago and finding that the crime rate peaked in areas with low natural surveillance).

37. PATRICIA Mayhew et al., CRIME AS OPPORTUNITY (Home Office, London, Research Study No. 34,1976 ). Similarly, those buses with only one operator had a rate of vandalism that was twenty times higher than those with additional operators. Id. American evidence shows that crimes are more likely on the New York subways when ridership is low. See R. Lance Shotland \& Lynne I. Goodstein, The Role of Bystanders in Crime Control, $40 \mathrm{~J}$. SOC. IssUES 9, 18 (1984).

38. Sally E. Merry, Defensible Space Undefended: Social Factors in Crime Control Through Environmental Design, 16 URB. AFF. Q. 397, 416 (1981); see also id. ("All agreed that the playground was a poor place to rob people because it is too visible. . . Robbers also take into account the number of people around."). In one study, a sample group of over 100 convicted burglars was shown videotape recordings of thirty-six dwellings, recorded in a manner meant to simulate the observations that a passerby might be able to make from the street. The researchers encouraged the offenders to "think aloud" while considering the videotapes, and the verbal responses were recorded and analyzed. The results indicated that houses offering significant "cover" were more desirable targets. For example, eighty-four percent thought that a detached house, "well covered by trees and bushes," was an acceptable target. In addition, burglars "argued that almost any obstruction, no matter how narrow, might be sufficient to break up their outline thereby making them less visible." TREVOR BENNETT \& RICHARD WRIGHT, BURGLARS 
There are three principal mechanisms that can be used to facilitate natural surveillance: diversity of building use, building design, and lighting.

Diversity of Use. Jacobs argued that diversity of use would bring people outdoors and increase natural surveillance. To generate adequate diversity, each city district should serve more than one primary function, and each function should occur during a different time of day so that there is some consistency in population throughout the day. ${ }^{39}$ To plan for diversity, a city cannot simply add a few incentives for businesses to operate in a particular locale; rather, it must cultivate the type of residents who work in harmony with the character of a given city district. ${ }^{40}$ Such cultivation requires an understanding of the primary uses of city districts and aggressive matching of those uses with incentives for secondary uses. Generic plans for innercity development, such as central business districts and civic centers, tend to ignore local conditions in lieu of wide-eyed hopes of generating massive changes to areas. ${ }^{41}$ In addition to large-scale planning, municipal housing decisions, from zoning to permits for new construction, could be redesigned to enhance diversity instead of eliminating it. ${ }^{42}$

Building Design. Jacobs's views on city planning are of course expensive and difficult to carry out all at once. In the forty years since the publication of her book, architects have experimented with many designs that alter individual buildings to enhance natural surveillance at lower cost. Here are a few examples: adding additional windows and placing them in high-traffic areas that look out onto public spaces; ${ }^{43}$ installing centralized

ON BURGLARY 58-62 (1984); see also GotTFREDSON \& HIRSCHI, supra note 24, at 25-26 (reporting similar findings).

39. JACOBS, supra note 30 , at $150-51$. More recent evidence also suggests that changing the way city blocks are laid out can decrease crime and the fear of crime. DONALD APPLEYARD ET AL., LIVABLE STREETS 245-48 (1981); TAYLOR \& HARRELL, supra note 31, at 7-10. In addition, landmark preservation laws can serve to increase natural surveillance and community bonds. See JESSICA L. DARRABY, ART, ARTIFACT, AND ARCHITECTURE LAW \& 14.02, at 14-13 to -20 (1995) (discussing federal historic preservation laws); JACOBS, supra note 30, at 252; Carol M. Rose, Preservation and Community: New Directions in the Law of Historic Preservation, 33 STAN. L. REV. 473 (1981) (arguing that such laws increase social ties in a community).

40. JACOBS, supra note 30, at 152, 158. A separate study of villages and census districts in England has confirmed Jacobs's intuition that diversity of use leads to greater surveillance. See JoANNa SHAPLAND \& JON VAGG, POLICING BY THE PUblic 23 (1988). The study found, for example, that in mixed-use neighborhoods, small businesses served as "watchers" and focal points for communication about crime, leading the authors of the study to criticize single-use zoning. Id. at 70-72.

41. JACOBS, supra note 30, at 162-69, 172, 402-03. Examples of urban design proposals to reduce crime include Nashville's Shelby Safewalk and Boston's Greenway project. See Michael Leccese, Urban Experiment, 85 LANDSCAPE ARCHITECTURE 22, 22 (1995) (discussing Nashville's project); J. William Thompson, Banking on a River, 85 LANDSCAPE ARCHITECTURE 50,55 (1998) (finding that the Charles River Greenway has become safer as more people use it).

42. It could be argued, however, that some forms of diversity might increase crime, as evidence suggests that crime occurs because of relative disparities in wealth. See ROBERT K. MERTON, SOCIAL THEORY AND SOCIAL STRUCTURE 234-35 (rev. ed. 1965).

43. Windows should be placed in areas that look out onto streets, and particularly in high-use areas, such as the kitchen. The American architect Christopher Alexander suggests creating 
air conditioning to eliminate the need for clunky window units that block natural surveillance; ${ }^{44}$ leaving hallway corridors and alleys topologically smooth to facilitate their visibility ${ }^{45}$ setting buildings against each other so that neighbors can watch others across a street or courtyard; using cul-desacs to facilitate natural surveillance in the fronts of buildings, ${ }^{46}$ building front stoops and porches; and returning to World War II "three-generation style" housing (in which houses had a separate apartment underneath them that facilitated monitoring and reciprocal interactions). ${ }^{47}$

Consider the placement of lobbies in apartment buildings. Elevator lobbies that are far from the building entrance and the street, or those that are reached only after passing through a series of corridors, reduce natural surveillance. When indispensable tasks, such as waiting for an elevator and receiving mail, are not observable to passersby and other residents, crime can increase. A comparison of two housing projects in the Bronx, one with a visible lobby and one without, revealed that the project with a visible lobby had a crime rate thirty-three percent below the New York City average while the other had a rate that was fifty-two percent higher than the average. $^{48}$

To illustrate these concepts, I have sketched out two drawings of a high school. ${ }^{49}$ The first shows the configuration of a school before crime prevention principles are applied:

"window places"-interior seats near windows-that direct the gaze outward. CHRISTOPHER ALEXANDER ET AL., A PATTERN LANGUAGE 837 (1977).

44. CROWE, supra note 18 , at 54.

45. This technique has been used to reduce crime in housing projects. NEWMAN, supra note 26 , at 95 . It is also not surprising that many inexpensive motels use such architecture when constructing their buildings.

46. The closed-off space can also facilitate territoriality and the use of common space for interaction and development. However, cul-de-sacs permit easier access in the back of buildings, which is why technological developments such as strong doors and powerful lighting provide greater benefits in those spaces. CRiME PREVENTION THROUGH HOUSING DESIGN, supra note 32, at 66 .

47. CROWE, supra note 18 , at 57.

48. Id. at 87. The two projects are Bronxdale Houses and Edenwald Houses.

49. These drawings build on the important work of Crowe. See CROWE, supra note 18, at 187-88. 


\section{FIGURE 1.}

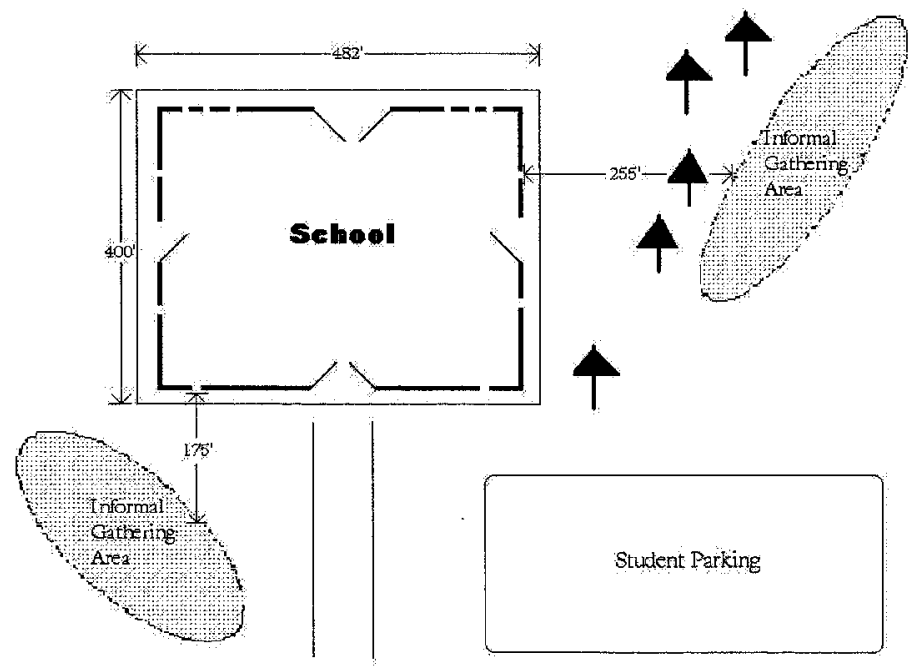

The informal areas are blocked from sight and far from school grounds. Because no central place for congregation exists, students are spread over the grounds, and there is insufficient density for monitoring. The four open entrances and exits facilitate access to the school and escape.

Now envision a redrawn plan, where formal gathering areas are designated: 
FIGURE 2.

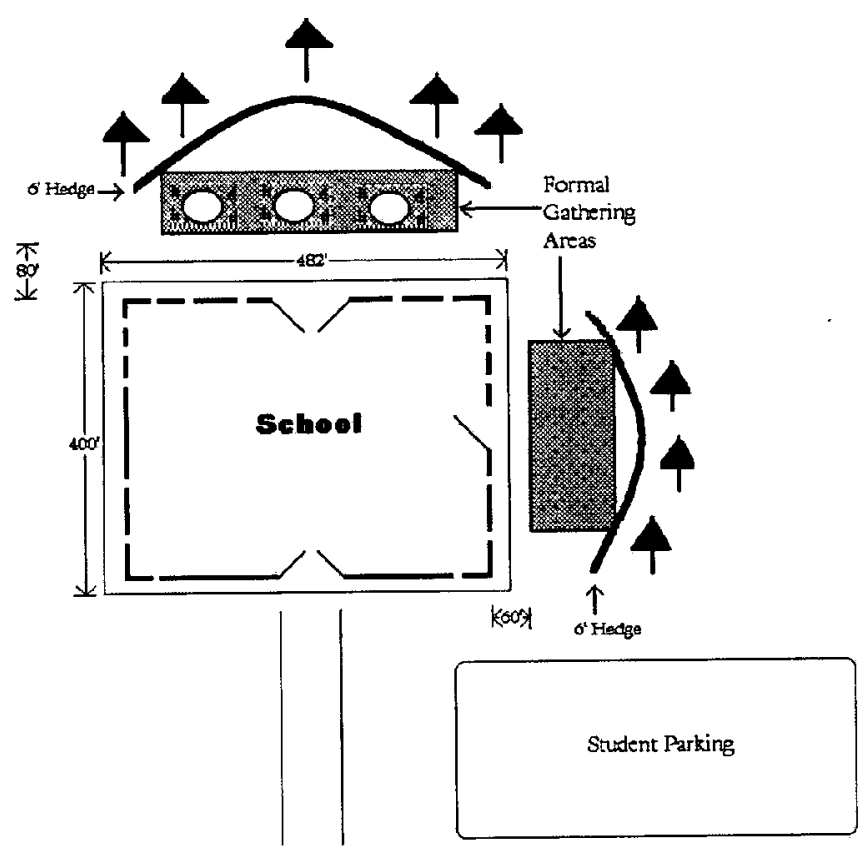

Through the designation of formal gathering areas, other places become subtly off-limits to students. Indeed, those who are present in such areas are likely to attract suspicion. And because the formal gathering areas are naturally surveilled by building users (now sixty or eighty feet away, not hundreds of feet), teachers and others inside the building can monitor those outside. The gathering areas are long and thin, running alongside the school windows, and two hedges prevent students from going farther away. Moreover, the west entrance, which had the least potential for natural surveillance, has been closed, thereby reducing access. Broward County, Florida, adopted an extensive crime prevention program in its schools based on these principles. ${ }^{50}$ Convenience stores have also used these architectural ideas to halve losses from theft and robbery. ${ }^{51}$ They have moved parking

50. Id. at 226-38; see also Don Blue, Safety by Design, at hitp://www.ismcpi.org/ ica/reference/CPTED-1998_04.htm (last visited Nov. 2, 2001) (providing many architectural devices to reduce crime and violence at schools, including clear lines of sight, better lighting, denotation of gathering areas, and parking lot restrictions); Safe Schools Design Guidelines, at http://www.fccdr.usf.edu/Projects/safe1.htm (last visited Nov. 2, 2001).

51. CROWE, supra note 18, at 9, 52,160; Carri Casteel \& Corinne Peek-Asa, Effectiveness of Crime Prevention Through Environmental Design (CPTED) in Reducing Robberies, 18 AM. J. PREVEnTIVE MED. 99, 109, 114 (2000) (finding similar results); see also Patricia D. Biles, 
lots to the front, to increase the visibility of customers' cars, and have strategically positioned cashiers and other employees for maximum surveillance of the store. They have also placed windows and torn down advertisements and signs in areas that permit gas station cashiers to observe the activities near the pumps.

Lighting. The benefits of lighting have been known for centuries. ${ }^{52}$ Lighting does two things. First, it helps anyone viewing a situation to see it more clearly and thereby deters some crimes by increasing the powers of perception of those already watching. Second, it encourages people to be in the area in the first place because the greater visibility creates a sense of security. The more eyes on the street, the more visibility constrains crime. ${ }^{53}$ "It is axiomatic that darkness is an ally to crime," J. Edgar Hoover remarked, stating that the "thief, the arsonist, the rapist, the Peeping Tom and all other perverse individuals often depend on darkness to cloak their misdeeds and conceal their identities." ${ }^{54}$

One analysis of parking facilities found that the "single most important" security precaution was lighting. ${ }^{55}$ A classic study showed that more property offenses were committed in London in the winter months and traced the increase in part to the longer periods of darkness in those months. ${ }^{56}$ British research today shows that forty percent of nighttime street crime occurs when lighting levels are at five lux or below (a typical side street has a lighting level of about 18,000 lux on a bright day and two lux at night), while only three percent of such crime occurs when the lighting is above twenty lux..$^{57}$

Reducing Workplace Violence in Late Night Retail Establishments, at http:/wwẉ.ismcpi.org/ ica/reference/CPTED-1998_02.htm (last visited Nov. 2, 2001) (discussing how physical barriers such as deep service counters and arrangement of furniture can prevent crime).

52. J.J. Tobias's excellent treatment of crime in nineteenth-century England, for example, explains how lighting transformed the crime rate:

"We are so familiar with well-lighted streets," wrote John Wade in 1829 , going on to stress that they formed "no inconsiderable branch of the police by guarding both persons and property from violence and depredation.... Every improved mode of lighting the public streets is an auxiliary to protective justice." As gaslighting spread ... it must have been a potent factor in making criminal activities more difficult.

J.J. TOBIAS, URBAN CRIME IN VICTORIAN ENGLAND 189-90 (1972).

53. Robert W. Chism, Lighting - First Line of Defense in Parking Structure Security, PARKING, Sept.-Oct. 1986, at 77 ("Ample lighting will both deter crime and present a secure at mosphere ... inviting high and repeated customer usage."). A third effect of lighting is to give potential offenders greater perception of bystanders and law enforcement. This prevents crime when bystanders and officers are present, but it may undermine prevention when they are not.

54. John Edgar Hoover, The Lighted Way, GEN. FED'N ClUB WOMAN, Feb. 1963, at 6.

55. SMITH, supra note 28; see also Federal Role in Urban Affairs: Hearing Before the Subcomm. on Executive Reorganization of the Senate Comm. on Government Operations, 89th Cong. 80, 210-11 (1966) (statement of Rep. Charles Farnsley); John Parker, Safer Spaces and Places: Reducing Crime by Urban Design 15 (Jan. 21, 2001) (unpublished manuscript, on file with author) (discussing new criminological data showing that lighting decreases crime and suggesting that it "increases community pride, sense of ownership and surveillance").

56. Cyril Burt, The Young DELINQUENT 160-65 (1925).

57. Crime Prevention Through Housing Design, supra note 32, at 49. 
The powerful effect of light on crime suggests that the common-law definition of burglary, which stipulated that it had to take place at night, functioned as a sentencing enhancement to deter a type of theft in which perpetrators were more likely to escape without detection. ${ }^{58}$ Marginal deterrence principles would require a higher sentence for a nighttime theft than a daytime one because the probability of being seen and detected was lower. However, as electricity became commonplace, the requirement that a burglary take place at night lost much of its significance, as lighting made the probability of detection at night at least as high as that during the day. It is, therefore, not surprising that modern codes take the view that the nighttime requirement is a mere technicality and not the essence of burglary.

Appropriate lighting means meeting the standards set by the Illuminating Engineering Society of North America, an entity that focuses on what types of lighting best reduce crime. ${ }^{59}$ In particular, lighting must have an adequate uniformity ratio because human eyes crudely adjust to varying degrees of light. If lighting is too uneven, or the glare too great, then natural surveillance will be reduced severely. ${ }^{60}$ Similarly, the tendency of many cities to use yellow street lights, which reduce electricity costs, can increase the crime rate by making streets (and individuals on them) look menacing. A few urban developers are replacing these yellow lights with white ones for that reason. ${ }^{61}$

In addition to the three mechanisms of diversity, building design, and lighting, natural surveillance can be fostered by creating "movement generators" that bring bystanders out of doors. Some ways to do this

58. If a "man's countenance may be discerned, it is called day: and when darknesse comes and day-light is past, so as by the light of day you cannot discerne the countenance of a man, then it is called night." EDWARD COKE, THE THIRD PART OF THE INSTITUTES OF THE LAWS OF ENGLAND 63 (photo. reprint 1979) (London, E. \& R. Brooke 1644). I am not claiming that such considerations actually undergirded the nighttime requirement or its eventual abandonment, only that the impact of light can explain why each rule made sense at the time. There were other reasons to treat burglary at night differently. See, e.g., 4 WILLIAM BLACKSTONE, COMMENTARIES *224 ("[T] me malignity of the offence does not so properly arise from it's being done in the dark, as at the dead of night... when sleep has disamed the owner, and rendered his castle defenceless."). Blackstone's argument may explain why many early cases upheld burglary convictions even when the moon was bright and offenders could be seen. E.g., Thomas v. Mississippi, 6 Miss. (5 Howard) 20, 20 (1840); New Hampshire v. Bancroft, 10 N.H. 105, 105 (1839) ("That the matter does not depend upon the degree of light, and the ability to distinguish objects at the time, is evident, because the light of the moon, however bright it may be, makes no difference.").

59. SMITH, supra note 28.

60. One cost-effective method of increasing the uniformity and brightness of light in a parking lot is to stain concrete. Stain is inexpensive, lasts many years, and creates strong brightness without requiring much maintenance. SMITH, supra note 28 . Lighting by itself, however, will not solve the crime problem even in commercial garages. Architectural features such as sloping floors in parking garages undermine natural surveillance and can increase the rate of crime. Id.

61. Interview with Andres Duany, Architect, in New Haven, Conn. (Nov. 26, 2001). 
include holding regular farmers' markets, organizing special-occasion festivals, and building porches and gardens. ${ }^{62}$

As important as natural surveillance is, it alone will not solve the crime problem. Bystanders may be reluctant to intervene and stop crimes. However, design might have an influence on such reluctance. Consider three possible effects. First, bystanders are likely to intervene when they see a crime rather than when they simply hear it-a finding with clear implications for natural surveillance. ${ }^{63}$ Second, the greater the number of people present in an area, the less bystanders will believe that intervention poses risks to themselves. ${ }^{64}$ Third, intervention is more common among bystanders who feel they are part of a community, and, as I discuss later, architects can design spaces to reduce social alienation. ${ }^{65}$

This last step points us in the direction of a more robust view of architecture and crime. Rather than simply creating visibility, architecture must also help develop the conditions under which people are more likely to intervene and act as watchers. For that reason, the architecture of crime control must carefully balance visibility and openness against other goals.

\section{Territoriality}

A second crime-prevention technique is to construct landscapes and buildings that create and reflect a sense of territoriality. Territoriality connotes ownership or stewardship of an area. It both provides an incentive for residents to take care of and to monitor an area and subtly deters

62. TAYLOR \& HARRELL, supra note 31 , at 10-14

63. R. Lance Shotland \& Charles A. Stebbins, Bystander Response to Rape: Can a Victim Attract Help?, 10 J. APPLIED SOC. PSYCHOL. 510, 518-22 (1980) (finding that sixty-eight percent of respondents would intervene in a simulated rape if they saw a woman forced into a room and heard a verbal exchange, whereas only thirteen percent would intervene upon only hearing the conversation).

64. Shotland \& Goodstein, supra note 37 , at 11-12 (observing that high perceived costs to intervention decrease its likelihood). It is also possible for natural surveillance to reduce bystander intervention due to collective action problems. See, e.g., John M. Darley \& Bibb Latané, Bystander Intervention in Emergencies: Diffusion of Responsibility, 8 J. PERSONALITY \& SOC. PSYCHOL. 377, 380 (1968) ("An individual subject is less likely to respond if he thinks that others are present."). This phenomenon may dampen some of the positive effects of natural surveillance, but it should be pointed out that additional visibility can counter self-interested assumptions and reveal that no others are likely to intervene. See id. at 378 (" [I]f others are known to be present, but their behavior cannot be closely observed, any one bystander can assume that one of the other observers is already taking action to end the emergency. Therefore, his own intervention would be only redundant ....").

65. See infra Subsection I.B.2. But see Merry, supra note 38, at 407-09 (stating that the failure of bystanders to intervene is more important than architecture); Paul van Soomeren, Safe and Secure Cities, The Physical Urban Environment and Reduction of Urban Insecurity: A General Introduction, Paper Presented at the Conference on the Reduction of Urban Insecurity, Barcelona, Spain, Nov. 17-20, 1987, at 8 (rev. ed. 1996) (unpublished manuscript, on file with author). 
offenders by warning them that they are about to enter a private space. ${ }^{66}$ Concern about territoriality should be balanced against the need for natural surveillance, so that spaces are neither too open nor too closed. If they are too closed, bystanders and residents cannot self-police; if they are too open, intrusion and crime could increase.

Architects can work to create territoriality by manipulating both the internal and external features of buildings. One way to accomplish this task is to use real barriers, such as locked doors and fences, and symbolic ones, such as a short series of steps or an archway. Real barriers are obviously more effective against a determined criminal, but they can impose heavy costs. Symbolic barriers will often be sufficient to warn potential offenders and help build a sense of territoriality among residents. An example of a successful symbolic barrier is an entrance raised by a few inches. Height can subtly convey distance and otherness. People are aware of minor gradations of elevation and may refrain from entry if they sense a gradual incline. Different colors and textures of surfaces can also be used to demarcate public and private spaces. ${ }^{67}$

A group of British architects has drawn two pictures that illustrate how symbolic barriers reinforce territoriality. In the first, a series of buildings lacks a common entrance, and pedestrians cut through the property:

66. Sidney N. Brower, Territory in Urban Settings, in 4 HUMAN BEHAVIOR AND ENVIRONMENT 179, 182-83 (Irwin Altman et al. eds., 1980); see also BENNETT \& WRIGHT, supra note 38, at 58 ("The aim of generating territoriality is to motivate residents to defend their own areas by encouraging informal social controls. This is intended not only to catch more offenders, but also to discourage strangers from entering the defended areas."); RICHARD MOE \& CARTER Wilkie, Changing Places: Rebuilding Community IN THE AGE OF SPRaWl 102 (1997) ("Fostering a shared sense of turf or 'territoriality' among residents of a community is a strong deterrent to crime and decay."); RALPH B. TAYLOR, HUMAN TERRITORIAL FUNCTIONING 260-61 (1988) (making the same argument); Brower, supra, at 188-89 (explaining how items like signs and pictures reinforce territoriality).

67. CRime Prevention Through Housing Design, supra note 32, at 68 (outlining this approach); CROWE, supra note 18, at 83, 99 (same). 


\section{FIGURE 3.}

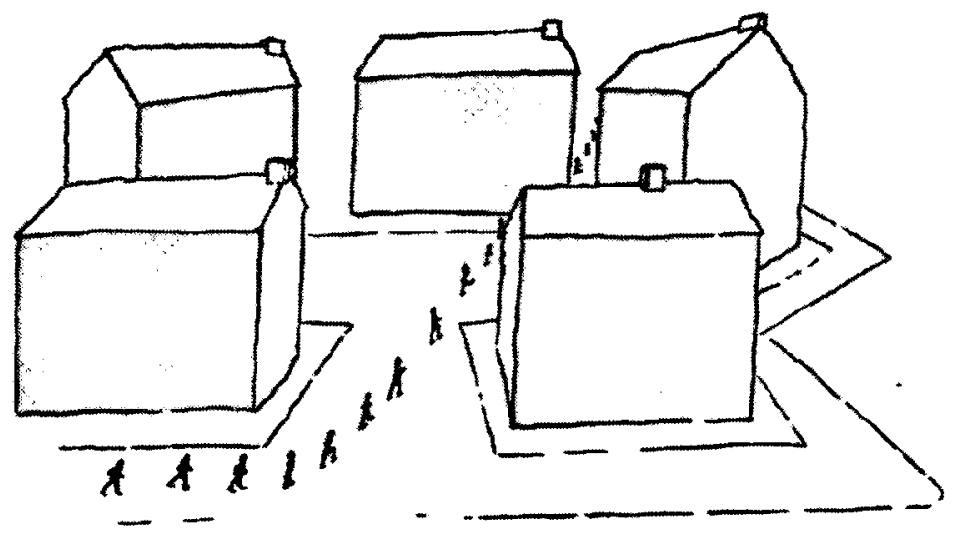

The addition of a simple overhead arch, however, creates a sense of private space:

FIGURE 4.

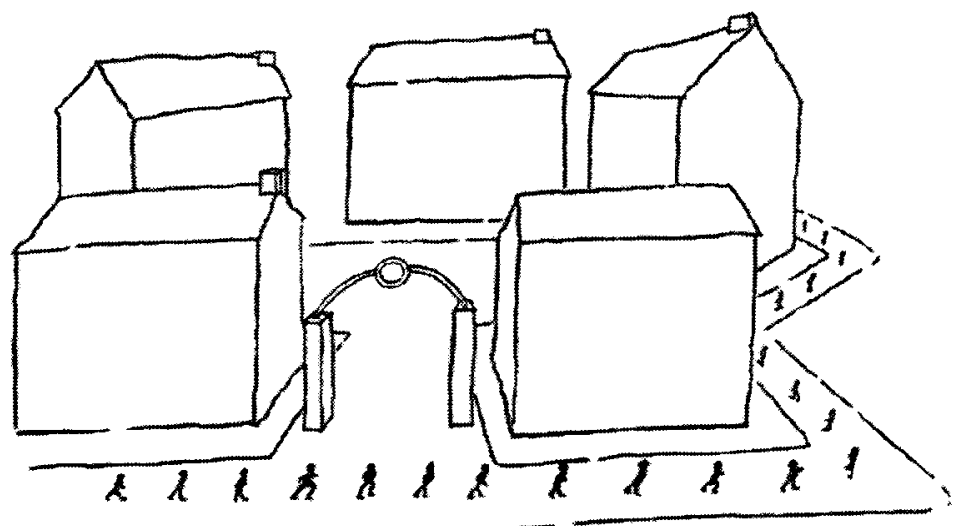

Empirical evidence suggests that housing projects that do not use real or symbolic barriers to demarcate private spaces have been the most crimeridden ${ }^{68}$ The most potent forms of barriers are not draconian, for the goal is

68. Crime Prevention Through Housing Design, supra note 32, at 45 (providing these two drawings); NEWMAN, supra note 26, at 66 (showing empirical support). By contrast, many crime-free projects use symbolic barriers such as placing three steps before an entrance to a unit. 
simply to create "apparency" - a vivid image in the mind of an observer. ${ }^{69}$ A study of burglaries in Salt Lake City, for example, revealed that houses with nameplates had lower rates of intrusion than those without them. ${ }^{70}$

In addition to using barriers, architects can reduce the number of people sharing special joint areas to encourage territoriality. These areas generally consist of entrances, elevators, stairwells, common balconies, open green areas, and parking facilities. ${ }^{71}$ Entryways that house few residents, such as six to twelve families, have been shown to create a sense of territoriality. ${ }^{72}$ By contrast, buildings with a single entrance for hundreds of residents preclude effective facial recognition of neighbors and other legitimate users. Buildings with fewer apartments per entryway have also been shown to lower levels of fear and rates of victimization. ${ }^{73}$ Similar results have been found in comparing elevator banks to separated elevator facilities. ${ }^{74}$ These insights are one example of Erving Goffman's more general point that members of communities below a certain size are more likely to interact and influence each other's behavior. ${ }^{75}$ In this way, territoriality serves to constrain excessive natural surveillance. It is better to have fewer invested neighbors than it is to have a greater number of passersby with little stake in an area.

Unfortunately, the undifferentiated design of many apartment buildings and housing projects induces residents to believe that the area outside their door is public and thus the sole responsibility of the police. Effective design, however, can construct housing in ways that create feelings of territoriality. ${ }^{76}$ Street design can also be used to reinforce territoriality

NEWMAN, supra note 26, at 124; see also GARDINER, supra note 30 , at 32 (discussing ways in which territoriality reduces crime). A psychology study found that a sign of care such as planting gardens or other vegetation is a "powerful territorial sign" that cues people to respect individual property and reduces the tendency to cut across someone's property or to commit more serious forms of trespass. Sidney Brower et al., Residents' Perceptions of Territorial Features and Perceived Local Threat, 15 ENV'T \& BEHAV. 419, 434 (1983).

69. See Kevin LynCH, The Image of THE CiTy 10 (1960) (describing the apparency concept).

70. Barbara B. Brown, Residential Territories: Cues to Burglary Vulnerability, 2 J. ArChitectural \& Plan. Res. 231, 234-35 (1985); see also Jon Lang, Creating ARCHITECTURAL THEORY 156 (1987) ("The way in which buildings and the spaces between them are designed affects pcople's perceptions of who should be in control of them.").

71. CROWE, supra note 18 , at 55 .

72. CRime Prevention Through Housing Design, supra note 32, at 57; NeWMAN, supra note 26 , at $67-68$.

73. TAYLOR \& HARRELL, supra note 31 , at 7 .

74. NEWMAN, supra note 26 , at 75 . Hallways with two to five apartments on them had a crime rate that was almost half that of hallways with six or more apartments. Id. at 69 .

75. GOFFMAN, BEHAVIOR, supra note 34, at 132-34. Goffman has shown that individuals "cognitively recognize" their neighbors even when they do not know tremendous amounts of personal information about them. Id. at 112-13.

76. One rather simple way is to place two buildings in an " $L$ " formation with a fence that completes the triangle. Children can play in the open space, and adults can look out of their windows at their children. NEWMAN, supra note 26, at 54-55 (discussing one such project, where "[s]trangers are easily recognized, and their activity comes under observation and immediate 
through signage, street limits, and devices to slow traffic. ${ }^{77}$ Interviews with burglars confirm that they avoid streets where access is restricted or where they must backtrack. ${ }^{78}$ Monuments and markers can also demarcate the transition from public space into private space.

\section{Building Community}

Another aspect of effective architectural design is the use of structures that build communities instead of dividing them. Ralph Erskine once remarked that "[t]he job of buildings is to improve human relations. Architecture must ease them, not make them more difficult." 79 Unfortunately, much architecture, particularly public architecture, does not maintain fidelity to such concepts. As William Julius Wilson observed in The Truly Disadvantaged, "In both the housing projects and other innercity neighborhoods, residents have difficulty identifying their neighbors. They are, therefore, less likely to engage in reciprocal guardian behavior. Events in one part of the block or neighborhood tend to be of little concern to those residing in other parts." 80

Natural surveillance emphasizes openness and visibility; territoriality highlights the need for some closures. The goal of building community straddles this tension, suggesting that spaces that are either too open or too closed can be harmful and that the creation of semipublic space can generate feelings of commonality. With certain forms of architecture, individuals will feel less isolated and less compelled to commit crimes, ${ }^{81}$ residents will find it easier to distinguish strangers from others, and bystanders will be much more likely to prevent crimes or come to the

questioning"). More generally, "architects can create a clear understanding of the function of a space, and who its users are and ought to be. This, in turn, can lead residents of all income levels to adopt extremely potent territorial attitudes and policing measures, which act as strong deterrents to potential criminals." Id. at 4.

77. See infra notes 214-216.

78. GEORGE RENGERT \& JOHN WASILCHICK, SUBURBAN BURGLARY 84-85 (1985); see also Vincent Scully, The Architecture of Community, in THE NEw URB ANISM 221, 221 (Peter Katz ed., 1994) (noting that architecture's "purpose is to mediate between the individual and the natural world by creating the physical reality of the human community, by which the individual is linked to the rest of humanity").

79. Marcus Binney, Unsung Hero ls in Tune with the Times, Times (London), Sept. 16, 1992, Arts, at 3.

80. William Julius WiLSON, THE TRULY DisadVANTAGED 38 (1987),

81. See RoberT J. BURSIK, JR. \& HAROLD G. GRASMICK, NEIGHBORHOOdS AND CRIME 53 (1993) (stating that isolation is a prime factor in predicting whether someone will engage in crime); Melvin L. Kohn \& John A. Clausen, Social Isolation and Schizophrenia, 20 AM. SOC. REV. 265 (1955) (making a similar argument linking isolation and mental illness); Ralph Taylor \& Jeanette Covington, Neighborhood Changes in Ecology and Violence, 26 CRIMINOLOGY 553 (1988) (presenting an empirical study of violent crime in Baltimare and finding a strong relationship between isolation and crime); Ralph B. Taylor et al., Block Crime and Fear: Defensible Space, Local Social Ties, and Territorial Functioning, 21 J. RES. CRIME \& DELINQ. 303,307 (1984) (arguing that design can increase social interaction and reduce crime). 
assistance of a victim after a crime takes place ${ }^{82}$ Many have argued that social isolation is dangerous for humans, leading to physical and psychological disorders ${ }^{83}$ Reducing social isolation can also help facilitate feelings of empathy, an emotion that can solidify reciprocity and reduce crime. As Robert Putnam explains,

People who have active and trusting connections to others... develop or maintain character traits that are good for the rest of society. Joiners become more tolerant, less cynical, and more empathetic to the misfortunes of others. When people lack connections to others, they are unable to test the veracity of their own views .... Without such an opportunity, people are more likely to be swayed by their worst impulses. ${ }^{84}$

Architects cannot solve these problems, but they can aid in the task of reducing feelings of isolation. Consider a study at Sarah Lawrence College. The College had two sets of dormitories, each of which housed approximately the same number of residents. The older dormitory consisted of three small buildings, each of which had two entrances and a small corridor. The newer dormitory was a massive single building with a large entrance. Interviews with the students discovered a "strong communal sense in each of the old buildings," but found that this sense was "nonexistent" in the new dormitory. ${ }^{85}$ Those in the new building "resisted any and all attempts by counselors and other students to shape them into social groups" and "[a]lmost universally ... adopted a loner's attitude." ${ }^{66}$ Incidence of vandalism and drug abuse was high in the new building and rare at the older buildings. ${ }^{87}$ These findings about dormitories also extend to

82. See Douglas D. Perkins et al., Participation and the Social and Physical Environment of Residential Blocks: Crime and Community Context, 18 AM. J. COMMUNITY PSYCHOL. 83, 88 (1990); supra text accompanying note 64.

83. E.g., EMILE DURKHEIM, SUICIDE: A STUDY IN SOClologY (John A. Spaulding \& George Simpson trans., Free Press 1951) (1897).

84. Robert D. Putnam, Bowling Alone 288-89 (2000). The converse is true as well; cohesive communities are the ones least likely to suffer from crime. Robert J. Sampson et al., Neighborhoods and Violent Crime: A Multilevel Study of Collective Efficacy, 277 SCIENCE 918, 923 (1997) (presenting an empirical study of Chicago finding that "the combined measure of informal social control and cohesion and trust remained a robust predictor of lower rates of violence").

85. NEWMAN, supra note 26 , at 75 .

86. Id.

87. Id. Similar results were found in a study of Berkeley dorms, SIM VAN DER RYN \& MURRAY SILVERSTEIN, DORMS AT BERKELEY 23-27 (1967), and other studies have confirmed these findings, see LEON FESTINGER ET AL., SOCIAL PRESSURES IN INFORMAL GROUPS (1950) (providing similar results in graduate school housing); GOFFMAN, BEHAVIOR, supra note 34, at 118-19 (discussing how acquaintanceship develops through informal contacts in public places); Robcrt R. Blake et al., Housing Architecture and Social Interaction, 19 SOCIOMETRY 133 (1956) (finding that architecture influenced social interactions in army barracks); Leo Kuper, Blueprint for Living Together, in LIVING IN Towns 1, 97 (Leo Kuper ed., 1953) (finding the same influence on interactions among neighbors). 
more mundane matters, as even the placement of seats and benches can bring people together or divide them, creating what architects call, respectively, sociopetal and sociofugal spaces. ${ }^{88}$ Some architects selfconsciously create sociofugal spaces by, for example, designing chairs in airports that make it difficult for people to talk to each other. ${ }^{89}$

One method of crime prevention, then, is to build spaces that facilitate unplanned social interaction. These spaces can be strategically located by placing them around waiting areas such as elevator lobbies, and areas in which people have to spend some time (the playground for parents, the mailboxes, the laundry room). Another simple strategy is to position door entrances on hallways (in buildings) and streets (for smaller residences) so that they face each other. Merton studied families who lived on opposite sides of a street and found that when residents' doors faced each other, they were much more likely to know their neighbors across the street-by a seventy-four to four percent margin..$^{90}$ Other work has demonstrated that the amount of time people linger in a common area is crucial for the development of social networks. ${ }^{91}$ Erving Goffman has shown that sight is a helpful tool in promoting communication between speaker and listener: "When persons come into one another's immediate physical presence, they become accessible to each other in unique ways." ${ }^{92}$ As residents come to

88. ITTELSON ET AL., supra note 2, at 140-41; see also ElZZABETH WoOd, HouSING DESIGN 5 (1961) (stating that seats and benches, as well as checker tables for adults, can also be used to bring people together and prevent crime); The Psychological Dimension of Architectural Space, PROGRESSIVE ARChITECTURE, Apr. 1965, at 159, 159 (stating that the "history of architecture contains innumerable examples of architectural spaces that have been consciously manipulated to draw people together or to disperse them," such as the New England village green).

89. Sommer describes airports as

perhaps the most sociofugal public spaces in American society. In most terminals it is virtually impossible for two people sitting down to converse comfortably for any length of time. The chairs are either bolted together and arranged in rows theater-style or arranged back-to-back .... The motive ... [appears to be] to drive people out of the waiting areas into cafes, bars, and shops where they will spend money. SOMMER, PERSONAL SPACE, supra note 7, at 121-22.

90. Robert K. Merton, The Social Psychology of Housing, in CURRENT TRENDS IN SOCLAL PSYCHOLOGY 163, 207-08 (Wayne Dennis et al. eds., 1948); see also Theodore Caplow \& Robert Forman, Neighborhood Interaction in a Homogeneous Community, 15 AM. SOC. REV. 357 (1950) (presenting a separate study of housing finding that residents whose front doors looked out onto common sidewalks were likely to know each other, even compared to neighbors that were closer but did not look onto common sidewalks). This research may explain why Molumby discovered that buildings with no other buildings directly across from them are responsible for sixty-five percent of crime even though they represent only thirty-nine percent of apartments in a particular neighborhood. Molumby, supra note 36 , at 256.

91. ITTELSON ET AL., supra note 2, at 140; Perkins et al., supra note 82, at 104-07 (reporting results from a survey of over 1000 New York City residents finding that physical environment is a good predictor of collective participation in block associations); Harold M. Proshansky et al., Freedom of Choice and Behavior in a Physical Setting, in ENVIRONMENTAL PSYCHOLOGY 173, 173 (Harold M. Proshansky et al. eds., 1970).

92. GOFFMAN, INTERACTION RITUAL, supra note 34, at 147. 
know each other, social organization can develop-leading to formal and informal ways of promoting community interests. ${ }^{93}$

Architects have also emphasized how front porches encourage interaction, so much so that some locales are experimenting with ordinances requiring front porches large enough for several people to sit down. ${ }^{94}$ The thinking is that if people will socialize on their front porches, then they will know their neighbors and be aware of any unusual activity. Architectural techniques can also make separate units look harmonious and help build a common identity. For example, trees can be planted close enough together to permit the foliage to look continuous instead of separate, and awnings can be designed similarly to work together over storefronts. ${ }^{95}$ In addition, some forms of architecture can create community symbols, thus contributing to a collective identity. ${ }^{96}$

Larger-scale solutions exist, such as minimizing the number of large apartment buildings. Environmental psychologists have found that those who live in apartment buildings tend to feel isolated, a feeling that is prevalent in high-rise buildings. A vivid illustration of this finding is the Pruitt-Igoe housing project, a St. Louis facility so crime-ridden that it was ultimately razed. According to a three-year study, crime festered in the complex because

the architectural design ... had an atomizing effect on the informal social networks frequently found in lower-class neighborhoods. Without the provision of semipublic space and facilities around which such informal networks might develop, families have retreated to the internal structures of their apartments and do not have the social support, protection, and informal social control found in other lower-class neighborhoods. ${ }^{97}$

93. LANG, supra note 70 , at 167 ("The built environment . . can be designed to facilitate the operation of a social organization ...."); WOOD, supra note 88, at 10-11 ("Design should help this aggregation of strangers become less strange, more familiar to each other. Out of this familiar[i]ty can come the informal communication, the informal groupings that constitute fabric.").

94. The front porch concept may also help multiethnic communities break racial tensions as people begin to look at each other as neighbors. See Barbara B. Brown et al., Neighbors, Households, and Front Porches: New Urbanist Community Tool or Mere Nostalgia?, 30 ENV'T \& BEHAV. 579 (1998).

95. JACOBS, supra note 30, at 390; see also GARDINER, supra note 30 , at 30 (finding a "direct link between the organization of the environment and the opportunity, and even probability, for crime").

96. See PAul SPENCER BYard, THE ARChitecture of AdDITIONS 79 (1998) (arguing that architecture "helps organize effective societies, providing monuments to focus their willingness to root for or against a home team"); LYNCH, supra note 69, at 4 ("A vivid and integrated physical setting... plays a social role as well. It can furnish the raw material for the symbols and collective memories of group communication.").

97. William L. Yancey, Architecture, Interaction and Social Control: The Case of a LargeScale Housing Project, in ENVIRONMENT AND THE SOCIAL SCIENCES 126, 129 (Joachim F. 
A comparison of a low-rise and high-rise project in New York (respectively, Brownsville and Van Dyke) revealed that the high-rise project had a much higher rate of crime. ${ }^{98}$ Because it lacked a sense of territoriality, police felt "callous and indifferent" toward invading its interior corridors, but these incursions by police could not by themselves maintain order. $^{99}$ The finding suggests that architecture can facilitate privacy; the self-governing public life of the low-rise project gave police a reason not to traverse private spaces.

Two other lessons have emerged from the architectural literature. First, city planning should try to maintain valuable social networks. Expressways that divide social spaces can often create crime on both sides of the divide. ${ }^{100}$ The same is true of railroad tracks and other forms of public construction. Second, creating an appealing environment will also build community. Cleanliness and aesthetic appeal can attract people to an area, thereby generating more actual and perceived safety and creating a feeling of neighborhood pride. Instead of seeing disorder and assuming that it is commonplace to contribute to further disorder, people will see order and be less likely to disturb it. When lawbreakers congregate in places such as

Wohlwill \& Daniel H. Carson eds., 1972). Other projects, such as one in Baltimore, consciously tried to bring residents together into common spaces, and the results were impressive: "[T]enants enjoyed better relations with neighbors, took part in more mutually supporting activities, made more new friends, and took more pride in the immediate neighborhood and community." ITTELSON ET AL., supra note 2, at 271; see also DANIFL M. WILNER ET AL., THE HOUSING ENVIRONMENT AND FAMILY LIFE (1962) (providing results from a Baltimore study).

98. Van Dyke had nearly twice as many felonies and several times the number of robberies as Brownsville, despite similarities of size, density, and demographic composition. NEWMAN, supra note 26, at 47 . While some believed that Van Dyke housed more "problem families," both projects housed similar residents. Id. at 45-46. The overwhelming difference was architecture, which changed the social interactions of the residents. In Brownsville, tenants left their doors ajar to maintain auditory surveillance and let their children play in the corridors. In Van Dyke, by contrast, the corridors were not designed for play, and parents were afraid to leave their doors open. Such behaviors impeded natural surveillance and furthered social isolation. The finding is striking because it shows how some explanations for crime, such as the breakdown of the family, may improperly discount architecture. Cf. OSCAR NEWMAN, COMMUNITY OF INTEREST 49 (1980) (describing interaction as a result of architecture).

99. NEwMAN, supra note 26, at 42. Moreover, the Van Dyke design made it difficult for law enforcement officers to patrol properly, a fact that may have led to additional callousness on the part of the police. $I d$. at 49 . This research suggests that architecture that facilitates surveillance may actually strengthen privacy.

100. ITTELSON ET AL., supra note 2, at 348 (stating that "the construction of major highways through central cities... fracture[s] and fragment[s] delicate social networks"); see also ALEXANDER GARVIN ET AL., URBAN PARKS AND OPEN SPACE 11-12 (1997) (discussing blight on both sides of Interstate 5 in Seattle); RENGERT \& WASILCHICK, supra note 78, at 62 (discussing how a Delaware turnpike divides a community); Scully, supra note 78, at 222 (describing how communities along Interstate 95 have been "physically tom apart and [their former members] given no opportunity to form new ones"); Wesley Skogan, Fear of Crime and Neighborhood Change, 8 CRIME \& JUST. 203, 206 (1986) (noting that the "freeway networks driven through the hearts of many American cities ... destroyed ... low-income, minority neighborhoods"). 
public parks, constraints on further lawbreaking erode. ${ }^{101}$ Furthermore, the group dynamics within enclosed spaces may lead to additional crime due to the tendency of groups to engage in riskier behavior. ${ }^{102}$ By eliminating visible disorder through architecture, the power of social organization to deter crime increases. ${ }^{103}$

\section{Strengthening Targets}

One of the more obvious ways in which architecture can prevent crime is by strengthening targets against attack. Some of these techniques are easy to employ, such as placing deadbolts lower on door frames, having doors in vulnerable locations swing outward, raising fire escapes to put them out of easy reach, and reducing the size of letter-box openings. Modern technology permits targets to be hardened in ways that are not obvious to the public. Strong plastics, graffiti-resistant paint, and doors with steel cores are a few examples. These advances allow architects to disguise their efforts at strengthening targets and thus avoid sending a message that crime is rampant. This message is, as I soon describe, an important feature that distinguishes various architectures of crime control.

Substantial evidence reveals that such security measures decrease crime in post offices, banks, and convenience stores. ${ }^{104}$ When the British town of Rochdale applied design principles to its housing projects (including the repair of doors and locks, better fencing around dwellings, and strong illumination), burglaries dropped by seventy-eight percent. ${ }^{105}$ Another study

101. Goffman states that:

[W] hen we find that places such as parks can become the scene of robbery, refuse dumping, sexual solicitations, loitering ... we must understand this collapse of public order not merely in terms of the fact that it may be possible to avoid the police in these places; we must understand that the involvement structure institutionalized in very loosely defined behavioral settings reduces appreciably the degree to which these nefarious acts are improper.

GOFFMAN, BEHAVIOR, supra note 34, at 215. For a discussion of park improvement, see infra text accompanying notes $217-224$.

102. David G. Myers \& Helmut Lamm, The Group Polarization Phenomenon, 83 PsYCHOL. BULL. 602, 602 (1976).

103. See Kahan, supra note 4, at 610 (discussing how social organization can deter crime).

104. See, e.g., Ronald V. Clarke \& Simon Field, Target Hardening of Banks in Australia and Displacement of Robberies, 2 SECURITY J. 84 (1991); Paul Ekblom, Preventing Post Office Robberies in London: Effects and Side Effects, 11 J. SECURITY ADMIN. 36, 38 (1988) (discussing security measures in post offices); Christian Grandjean, Bank Robberies and Physical Security in Switzerland, 1 SECURITY J. 155 (1990) (finding that thirty-four percent of banks that encased tellers with bulletproof glass had a robbery or an attempted robbery, whereas sixty-five percent of those without such glass had a robbery or attempt); Ronald D. Hunter \& C. Ray Jeffrey, Preventing Convenience Store Robbery Through Environmental Design, in SITUATIONAL CRIME PREVENTION 194, 200-04 (Ronald V. Clarke ed., 1992) (discussing security measures in convenience stores).

105. Crime Prevention Through housing Design, supra note 32 , at 75-77. When several Chicago housing projects employed such techniques, an overwhelming majority of tenants stated that they believed that drug dealing and physical violence had declined. See John E. Eck, 
of two British housing projects found that improved locks and doors reduced burglaries by ninety percent in one area and fifty-nine percent in the other, relative to a control area. ${ }^{106}$

To illustrate the importance of protection of targets, I have sketched out a common plan for a bank:

FIGURE 5.

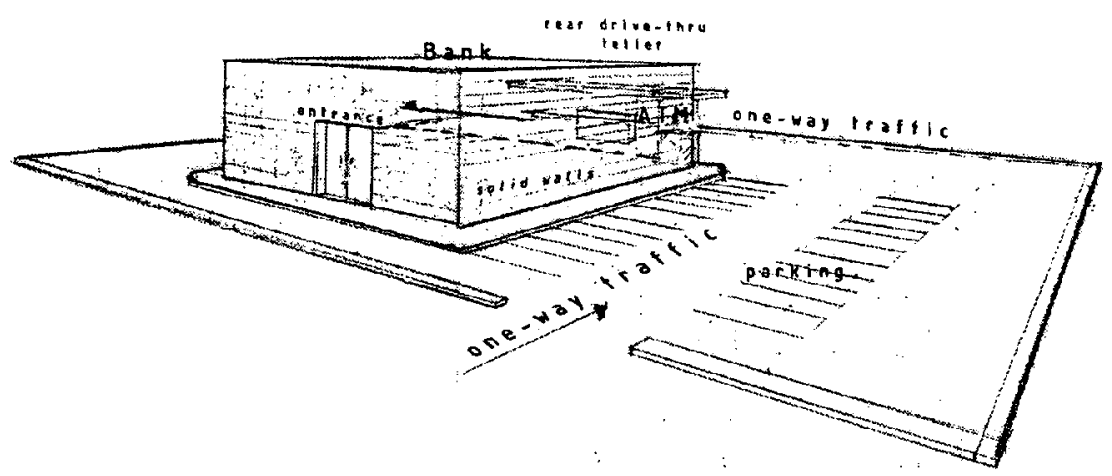

The bank was constructed as a fortress, with few windows and with walls that blocked visibility. But experience showed that thieves preferred such designs because natural surveillance was lacking. ${ }^{107}$ In addition, the ATM was placed in the back of the bank so that bank tellers, who were in the back, could easily service it. However, this design located the machine in an area with little natural surveillance. The parking lot, which architects believed should be hidden from public view because it was an eyesore, was also placed in an area that few could see. (Note the solid wall between the

Preventing Crime at Places, at http://www.ncjrs.org/works/chapter7.htm (last visited Nov. 1, 2001). Similar results were found for a British public housing facility. Id.

106. NichOlas TILly \& JANICE WEBB, BURGLARY REDUCTION: FINDINGS FROM SAFER CrTIES SCHEmes (Home Office Police Dep't, London, Crime Prevention Unit Paper No. 51, 1994). When a housing project, Potomac Gardens, in Washington. D.C., installed an eight-foot fence around its buildings, the number of arrests there dropped from 150 to seven in one year. Serge F. Kovaleski, Drastic Measures for a Desperate Place: Fences May Mean Freedom at D.C. Housing Complex, WASH. POST, July 11, 1994, at D4.

The elimination and minimization of hiding places and dead spaces will also prevent crime. CRIME PREVENTION THROUGH Housing DESIGN, supra note 32, at 26; John Parker, Safer Spaces \& Places: Reducing Crime by Urban Design, Paper Presented at the Council of Europe Conference on the Relationship Between the Physical Urban Environment and Crime Patterns 11 (2000) (unpublished manuscript, on file with author). Interviews with burglars confirm that they pick locations with overgrown shrubbery, for example. RENCERT \& WASILCHICK, supra note 78, at 86, 92. Such interviews also reveal that small windows actually promote crime, as they are "easier to break or open" than large ones. BENNETT \& WRIGHT, supra note 38, at 67-68.

107. See CROWE, supra note 18, at 164-67 (making these observations about bank security). 
parking lot and the inside of the bank.) As a result, bank patrons were at risk of being robbed upon leaving the premises. Now consider this redesign:

FIGURE 6.

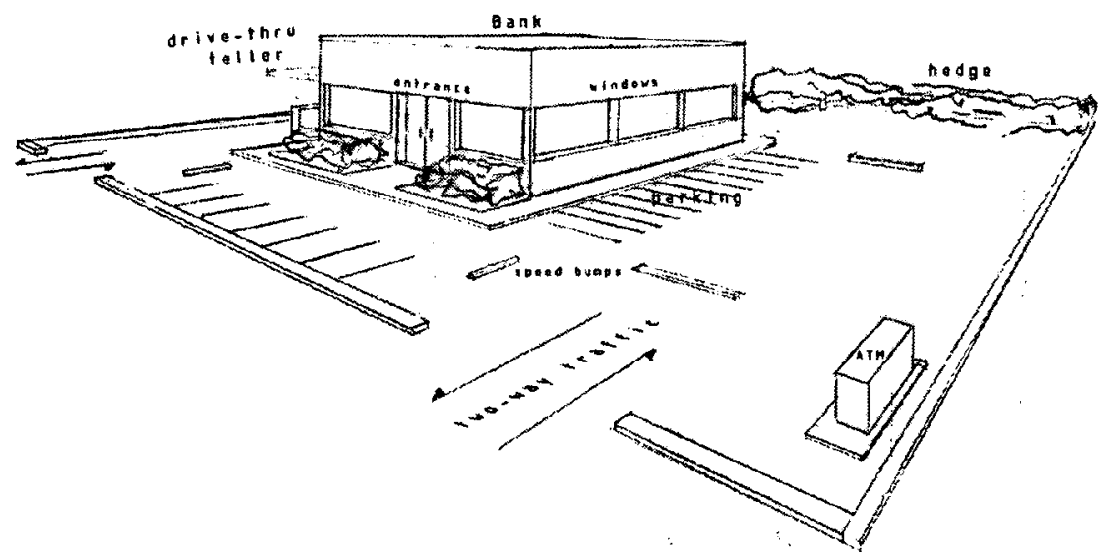

The redesign places both the parking lot and the ATM in the most visible part of the area, permitting greater natural surveillance and enabling users to get back into their cars quickly after using the machines. Interviews with bank robbers have found that they prefer banks where it is difficult to see in (to minimize the power of natural surveillance) and easy to see out (to plan their escape and watch for law enforcement officers). ${ }^{108}$

Careful attention to the placement and design of building entrances makes buildings less accessible to criminals. To take an obvious example, if a robber can stand on top of a trash bin and reach a second-floor window, the bin should be placed somewhere far from the window. ${ }^{109}$ Prickly shrubs placed outside of reachable windows can also deter crime. A duct that spews hot air can be placed near a ground-floor window to deter entry. Smells can also be strategically harnessed either to induce people to come outside or to keep them away. ${ }^{10}$

In order to fortify targets of crime, communities may at times have to reduce the number of public streets available to criminals. Such strategies should obviously be employed only in carefully selected settings, but

108. W.D. Tiffany \& J.M. Ketchel, Psychological Deterrence in Robberies of Banks and Its Application to Other Institutions, in THE ROLE OF BEHAVIORAL SCIENCE IN PHYSICAL SECURITY 81, 83 (J.J. Kramer ed., 1979).

109. Crime Prevention Through Housing Design, supra note 32, at 71.

110. Real estate brokers understand the power of smell $\longrightarrow$ often baking bread in the oven before showing a house in order to create a warm smell of familiarity and to mask any negative odors. Stores that emit such smells, such as cookie shops, can serve a special purpose (or two) by encouraging people to come outdoors and thereby create natural surveillance. 
controlling access routes has been shown to decrease crime. ${ }^{111}$ When North London closed a series of roads in the hope of eliminating drive-through "john" traffic, arrests for all crimes dropped and "within a relatively short period of time, a remarkable transformation occurred[-] the area was transformed from a noisy and hazardous 'red light' district into a relatively tranquil residential area." 112

Los Angeles recently experimented with a major initiative to reduce gang violence through architecture. Faced with an escalating gang problem, analysts believed that certain streets were allowing gang members to access targets of crime easily and to escape quickly afterward. Once the city placed traffic barriers on some of these streets, assaults fell from 190 to 163 in the first year, and from 163 to 138 in the next year; homicides dropped markedly as well. ${ }^{113}$ The city had designated a "control site" - a similarly situated neighborhood that did not use the barriers-and homicides and assaults did not decline at the site. The city also studied whether crime increased in communities that neighbored the new barriers and found no significant increase. ${ }^{114}$

111. See ARnold Sagalyn et al., U.S. Dep't of Justice, Residential SeCURITY 37-38 (1973); TAYLOR \& HARRELL, supra note 31 (finding that when North Miami built barriers to reduce street traffic, it reduced the incidence of auto theft and assault); Ralph B. Taylor \& Stephen Gottfredson, Environmental Design, Crime, and Prevention: An Examination of Community Dynamics, in 8 CRIME \& JUST. 387, 392 (1986); Garland F. White, Neighborhood Permeability and Burglary Rates, 7 JUST. Q. 57, 65 (1990) (finding in a study of burglary in Norfolk, Virginia, that neighborhoods with many interior streets had high burglary rates). Some European cities have also created "control zones" where single entrances and exits are employed to protect sensitive areas, from a sidewalk to a full neighborhood. See Thomas Vonier, Halt: Who Goes There? Urban Control Zones in Europe Offer Important Lessons for Securing U.S. Cities, 85 ARCHITECTURE 71, 73 (1996).

112. Roger Matthews, Developing More Effective Strategies for Curbing Prostitution, 1 SECURITY J. 182, 185 (1990).

113. James Lasley, "Designing OUT": Gang Homicides and Street Assaults 2-3 (Nat'l Inst. of Justice, Research in Brief, Nov. 1998); Press Release, Los Angeles Police Department, Stamp Out Crime Through Environmental Design, at http://www.lapdonline.org/ press_releases/2000/01/ocop8.htm (last visited Nov. 29, 2001). These reductions are statistically significant, even when other factors that might have reduced the crime rate are taken into account. LASLEY, supra, at 3.

114. LASLEY, supra note 113, at 4 . The researchers surmised that geographic substitution did not occur because the gangs could not expand to other areas without threatening the turf of neighboring gang members.

In another intensive survey, the Land Use Research Unit at King's College, London, studied more than 4000 blocks of low-income apartment buildings accommodating approximately a quarter of a million people. Results were compared to a control group of over 4000 houses. ALICE COLEMAN ET AL., UTOPIA ON TRIAL, at vii (1985). The study explored whether certain design features-such as the number of dwellings per entrance, the number of floors per dwelling, the position of the entrance, and the number of access points to the dwelling-contributed to high crime rates. It also investigated whether these design features were associated with the presence of signs of social malaise, such as litter, graffiti, vandalism, and public excrement. The results of the experiment strongly indicate that crime, as well as the signs of social malaise, result from poor architectural design. Poor design also resulted in higher private and insurance losses and in higher social costs in the sufferings of crime victims, and it required higher public expenditure for policing, courts, and prisons. Id. at 177-78 ("As each design variable worsens, there is an 
The federal government often employs target-hardening to protect its sensitive buildings. The FBI building is built on stilts to minimize damage in the event of a bomb detonation at street level. To decrease the likelihood of presidential assassination, a stretch of Pennsylvania Avenue in front of the White House was barricaded and closed to car traffic. ${ }^{115}$ The prevalence of these sorts of architectural solutions, however, should not obscure the other three goals of crime control through architecture. This is particularly important because some forms of target hardening are suboptimal in that their visibility evinces a fear of crime that can cause damage to the fabric of a community and even increase crime rates. ${ }^{116}$ More attention to other methods of architectural precaution can minimize the tendency to think only in terms of target protection.

In sum, increasing natural surveillance, fostering territoriality, reducing isolation, and protecting targets are strategies that architects use to prevent crime and to control its impact. The efficacy of each strategy will vary by context, and sometimes the pursuit of one goal will necessarily exclude another goal. Accordingly, architects must develop a set of principles to assess how architecture prevents crime. The search for these principles necessarily requires a step back, to a more general claim about what factors constrain criminal activity.

\section{B. Four Constraints on Crime}

Legal scholarship has been largely single-minded in its focus on one constraint, public enforcement of the law through police and prosecutors. In recent years, a burgeoning literature has explored the role of social norms in preventing crime. A less obvious, but equally important, constraint is perpetration cost. That is, if crime is expensive to commit (or creates a risk of physical injury to the perpetrator), individuals will be more likely to refrain from it. Architecture affects these constraints in dramatic ways. It increases the power of law enforcement and its ability to deter crime,

increasing probability that more families will fail, in more ways, to develop their children's capacity for adjusting to civilised life ...."). The study's authors concluded that crime can be reduced through the use of window and entryway design, limits on the height and size of buildings, and restriction of access. Id. at 170-74. Such methods also increased social interaction. See id. at 72.

115. Some have suggested that damage from the Oklahoma City bombing would have been mitigated if the designers had taken certain architectural principles into account. E.g., Nadine M. Post, Defensible Space: More than Merely Cops and Robbers, ENGINEERING NEwS REC., May 1, 1995 , at 18, 26. Early buildings, such as the Federal Reserve Board depositories, used architectural principles to prevent crime. Minnesota v. Fed. Reserve Bank, 25 F. Supp. 14, 17 (D. Minn. 1938) ("The primary object in designing and constructing the building was to erect a structure that would safely preserve the funds and securities in the care of the defendant in the event of fire, burglary, or mob attack."). III.D.

116. These concerns are taken up infra text accompanying notes 171-172 and in Section 
facilitates the creation of public social norms that constrain crime, helps shape the tastes of individuals away from criminal activity, and increases the perpetration cost of lawbreaking.

In the following sections, I explore each of these constraints as they relate to architecture. Readers will note that several strands of the argument regarding these constraints have been implicit thus far. Specific consideration of architecture within the matrix of these constraints, however, furthers the analysis. Before applying the matrix, it is worth highlighting one feature that cuts across the constraints: unconscious influence. Some architectural strategies will work even without the conscious involvement of the criminal or the public. This feature contrasts with crime-control strategies based on legal sanctions or public norms, which generally work best when a potential offender has knowledge of them. As Lawrence Speck, the Dean of the University of Texas School of Architecture puts it, architecture operates "much more [on the] subconscious than [the] conscious. Architecture is all about subliminal experience.... You listen to music, you look at a painting. But you live in architecture, and it affects you whether you're even conscious of it." 117 Architecture thus can be effective at many points in the spectrum of consciousness.

Psychological evidence shows that criminals decode environmental "cues" to assess the likelihood of success of a given criminal act. ${ }^{18} \mathrm{~A}$ classic study, with implications for natural surveillance, showed that children are also more likely to act dishonestly when there is less supervision around them. ${ }^{119}$ In another important study, Steinzor found that the design of a meeting table influences who will speak and when, and who

117. Avrel Seale, Architect Lawrence W. Speck and "The Vision Thing," TEX. AlCALDE, July-Aug. 1999, http://txtell.lib.utexas.edu/stories/s0007-full.html; see also Murray Edelman, Space and the Social Order, 32 J. ARCHTECTURAL EdUC. 2, 5 (1978) "Architectural cues that are most potent when they function subconsciously reaffirm many other kinds of social relationships as well ....").

118. Taylor \& Gottfredson, supra note 111, at 401 (suggesting that criminals "decode" physical cues); see also MIRILIA BONNES \& GIANFRANCO SECCHIAROLI, ENVIRONMENTAL PSYCHOLOGY 88-89 (Claire Montagna trans., Sage Publ'ns 1995) (1992) (noting studies in territoriality that show that how a territory is defined, in terms of physical and symbolic barriers, determines how it is defended against others); Thomas Gabor, Crime Displacement and Situational Prevention: Toward the Development of Some Principles, 32 CAN. J. CRIMINOLOGY 41,54 (1990) (describing research arguing that some environmental cues act as releasers in that they stimulate release of an inhibited behavior against crime); Douglas $\mathrm{D}$. Perkins et al., The Physical Environment of Street Blocks and Resident Perceptions of Crime and Disorder: Implications for Theory and Measurement, 12 J. ENVTL. PSYCHOL. 21, 21-23 (1992) (studying the relationship between perceived "fear" of residents of a community and actual "incivilities" committed).

119. Hugh Hartshorne \& MARK A. MAY, STUdies IN DECEIT (1928). Natural surveillance creates both conscious deterrence (some criminals knowingly refrain from action while bystanders are present) and unconscious deterrence (the presence of bystanders may lead some perpetrators to be more aware of the costs of their acts). 
is perceived to have a position of authority. ${ }^{120}$ It is therefore no great shock that the eight months of negotiations that preceded the 1969 Paris Peace Talks largely centered on what the physical shape of the negotiating table would be. ${ }^{121}$ It is said that Machiavelli designed a political meeting chamber with a ceiling that looked as if it were about to collapse, reasoning that it would induce politicians to vote quickly and leave. ${ }^{122}$

\section{Legal Sanctions}

Architecture can facilitate law enforcement in five respects. First, it can help police catch criminals. When Bridgeport, Connecticut, wanted to slow the drug trade, it erected a series of concrete barriers near a highway running through the city. The city knew that suburbanites were pulling into Bridgeport to buy drugs and then quickly leaving town, and it correctly reasoned that barriers to slow traffic down would deter drug purchases. ${ }^{123}$ Customers were afraid to come into Bridgeport because they knew that law enforcement had a better chance of catching them.

Second, architecture can make it easier for police to intervene in an evolving incident. Police are more comfortable going into areas with strong natural surveillance and are more likely to enter peacefully when they believe that residents will take care of them and monitor the situation. ${ }^{124}$

Third, the presence of many bystanders at a crime scene can increase the level of trust between police and the bystanders, leading the police to additional information. A crowd of bystanders is less likely to fear a police officer than are one or two bystanders. Therefore, as architects bring natural surveillance to an area, they may ease community-police tensions.

Fourth, architecture can facilitate the identification of criminals after a crime has been committed. By putting more people on the streets and lighting facilities properly, a city makes it more likely that a given crime

120. Bernard Steinzor, The Spatial Factor in Face-to-Face Discussion Groups, $45 \mathrm{~J}$. ABNORMAL SOC. PSYCHOL. 552 (1950); see also ITTELSON ET AL., supra note 2, at 138 (reporting similar results). Studies show that people who sit at right angles from each other at a table are six times more likely to engage in conversation than those who sit across from each other. See EDWARD T. HALL, THE HIDDEN DIMENSION 102 (1966).

121. ITTELSON ET AL., supra note 2, at 139.

122. CrowE, supra note 18, at 84-85; see also David Stea, Territoriality, the Interior Aspect: Space, Territory, and Human Movements, LANDSCAPE, Autumn 1965, at 13, 15-16 (discussing how alteration of the size and shape of rooms can have dramatic impacts on behavior).

123. There were, however, serious problems with the implementation and design of the barricades. See supra note 31. Dayton, Ohio, used a more sophisticated barrier strategy that facilitated crime control. See infra note 211.

124. NEWMAN, supra note 26 , at 204. Victim surveys and interviews with convicted criminals reveal that "the mere presence of bystanders reduces the likelihood of crime." Shotland $\&$ Goodstein, supra note 37 , at 9,18 . On the other hand, police might fear a mob of residents, particularly in areas hostile to law enforcement. 
will be observed. A higher probability of accurate witness information thus exists when architectural design strategies are employed.

Fifth, an understanding of architecture and crime can help police deploy their resources in areas where crime is likely to fester. As a Hartford, Connecticut, study found, "The physical environment affects the task of police to the extent that opportunities for crime are structured. To the extent that there are fewer places where offenders may operate freely, either because of environmental effects on offenders or on citizens, the task of police patrol is made easier." 125

Gary Becker's celebrated article argues that two variables are equally important to deterrence: the probability of enforcement and the sanction imposed. ${ }^{126}$ Some recent evidence suggests, however, that the probability of enforcement matters more to criminals than the maximum length of sentence. ${ }^{127}$ If this finding is correct, then architecture is particularly important because it increases both perceived and actual probabilities of enforcement. Although architecture obviously cannot change the maximum sentence imposed by law, it can alter the more significant variable.

\section{Social Norms}

Because law enforcement cannot and should not be omnipresent, society's mores can play a useful role in constraining crime. Architecture works on two levels to facilitate governance through social norms. The more obvious way is by empowering ordinary citizens, who are given a greater ability to monitor and prevent wrongdoing in a community. Design can influence a community's perception of safety and territoriality, and, in turn, its tolerance for criminal acts. The less obvious, though perhaps more important, mechanism is for architecture to shape individuals' attitudes toward lawbreaking. I take up this subtle mechanism in the next Subsection.

Architecture empowers ordinary residents through techniques such as natural surveillance, territoriality, and the reduction of social alienation. Such techniques draw people outdoors and make members of a community visible to each other, thus increasing both social pressure against crime and the probability of detection. Norms are ineffective when residents live in atomized apartments where interaction seldom occurs. Even the best social codes are quite useless if it is impossible to observe whether people comply with them. Architecture, by facilitating interaction and monitoring by members of a community, permits social norms to have greater impact. In

125. FOWLER ET AL., supra note 34, at 5-6. (1968).

126. Gary S. Becker, Crime and Punishment: An Economic Approach, 76 J. POL. ECON. 169

127. E.g., Dan M. Kahan, Social Influence, Social Meaning, and Deterrence, 83 VA. L. REV. $349,379-80$ (1997). 
this way, the power of architecture to influence social norms can even eclipse that of law, for law faces obvious difficulties when it attempts to regulate social interaction directly. ${ }^{128}$

Erving Goffman's sociological studies confirm the power of unplanned social contacts on behavior. His work reveals that behavior is changed even when one is not fully conscious of the presence of others. ${ }^{129}$ These unfocused interactions can be converted into focused ones, such as when a bystander inserts herself into a situation. While eye-to-eye encounters create the most important forms of interactions, including those that are most likely to change behavior, Goffman believes that conduct will be altered, whether the interaction is focused or unfocused. ${ }^{130}$ Criminologists also have emphasized the importance of true social interaction in reducing crime. ${ }^{131}$ This observation suggests that artificial methods, such as closedcircuit television cameras, will not fully capture the benefits of surveillance, because they do not have the same mutuality of interaction. ${ }^{132}$ The observation also suggests that when the two architectural goals of territoriality and natural surveillance come into conflict, the former goal will generally yield greater crime prevention benefits than the latter.

In particular, bystanders are more likely to intervene to prevent crimes when strong social interactions in a community exist. ${ }^{133}$ Studies of altruism also show that people are much more likely to act cooperatively when they

128. SKOGAN, supra note 22 , at $170-71$.

129. Goffman observes:

Half-aware that a certain aspect of his activity is available for all present to perceive, the individual tends to modify this activity, employing it with its public character in mind.... And even if those in his presence are not quite conscious of the communication they are receiving, they will none the less sense something sharply amiss should the uncustomary be conveyed.

GOFFMAN, BEHAVIOR, supra note 34, at 33; see also id. at 88-92 (arguing that police should become more involved in the community to curtail crime).

130. Id. at $92-95$.

131. Mukherjee and Wilson note that "[t]he most important element of community-crime prevention appears to be to bring about social interaction ... [because] interaction and familiarity should ... make it possible to detect strangers in the community ... [and] lead to a cohesive neighbourhood." SATYANSHU MUKHEREE \& PAUL WILSON, NEIGHBORHOOD WATCH 2 (Austl. Inst. of Criminology, Trends and Issues in Crime and Criminal Justice No. 8, 1987).

132. GOFFMAN, BEHAVIOR, supra note 34 , at $15-16$ \& n.5 (discussing how communication with naked senses creates more interaction between individuals than that through artificial means).

133. Eleanor E. Maccoby et al., Community Integration and the Social Control of Juvenile Delinquency, 14 J. SOC. ISSUES 38 (1958); see also Shotland \& Goodstein, supra note 37, at 1213 (collecting studies). A study of Chicago found that a neighborhood's "collective efficacy," or its mutual trust and willingness to intervene when neighbors' children are misbehaving, is one of the most important factors in predicting crime rates, eclipsing even poverty. Robert J. Sampson et al., Neighborhoods and Violent Crime: A Multilevel Study of Collective Efficacy, 277 SCIENCE 918 (1997); see also Greg Saville \& Gerry Cleveland, Second Generation CPTED: An Antidote to the Social Y2K Virus of Urban Design 1-2 (Nov. 1, 2001) (unpublished manuscript, on file with author) (stating that social propensity to intervene is important). 
perceive a common social identity. ${ }^{134}$ Experimental social psychologists have uncovered striking evidence that even the most casual social interaction can have a powerful effect on reciprocity. For example, when subjects have met and spoken to each other for a single minute, they are far more likely to intervene to help each other in the event of an emergency than had they not met, and they will intervene more than twice as quickly. ${ }^{135}$

Minimal cooperation can change behavior in profound ways. Consider the following experiment: Certain homeowners in Palo Alto were asked to place a large and crude sign saying "drive carefully" in the front of their homes. Only seventeen percent of homeowners agreed. Other homeowners were asked to perform a small task, either sign a petition or place a threeinch-square sign in their cars, and the "vast majority" of owners so agreed. Two weeks later, these individuals were approached to put up the large crude sign, and seventy-six percent of them did so-nearly five times the percentage of the first group. ${ }^{136}$ These findings have been replicated with many subsequent studies in a variety of locations and involving a number of different messages on the sign. ${ }^{137}$ This research suggests that a community can be built with a few small acts that eventually culminate in larger ones, and the first small acts can be prodded along through architecture.

Put slightly differently, architecture can help a community amass social capital. Social capital refers to the value created by networks of individuals that are characterized by trust and reciprocity. ${ }^{138}$ Informal connectionssuch as having people over for dinner, playing cards, and small talk in lobbies - can augment social capital by building networks of trust. ${ }^{139}$ When individuals believe that others are more likely to intervene and help out, mutually beneficial cooperation ensues. The influential theorist Robert Putnam offered many explanations for the decline of social capital, such as

134. Robyn M. Dawes et al., Cooperation for the Benefit of Us-Not Me, or My Conscience, in BEYOND SELF-INTEREST 97, 99 (Jane J. Mansbridge ed., 1990) ("[E]xperiments have led us to conclude that cooperation rates can be radically affected by ... group identity.").

135. BIBB LATANÉ \& JOHN M. DARLEY, THE UNRESPONSIVE BYSTANDER 107-09 (1970); see also Robyn M. Dawes, Social Dilemmas, 31 ANN. REV. PSYCHOL. 169, 185 (1980) (noting that "[t]he salutary effects of communication on cooperation are ubiquitous" and citing studies); Meares, supra note 21, at 395 ("Norm enforcement is easier when individuals in a community have social linkages and trust one another."); David Sally, Conversation and Cooperation in Social Dilemmas: A Meta-Analysis of Experiments from 1958 to 1992, 7 RATIONALITY \& SOC'Y $58,67,83$ (1995) (describing how permitting visual contact in cooperation experiments increases the extent of altruism).

136. LeE Ross \& Richard E. NisbetT, The PERSON AND the Situation 50-51 (1991).

137. Id. at 51-52 (discussing studies).

138. PUTNAM, supra note 84 , at 19.

139. Id. at 93. Putnam distinguishes between "thick trust," which refers to trust among individuals who know each other personally, and "thin trust," which refers to the background principle of trust among individuals in a community who are unfamiliar with each other. Id. at 136. "Thick trust" strategies would focus much more on territoriality; "thin trust" ones focus more on natural surveillance. 
pressures of time and money, mobility and sprawl, and generational change. ${ }^{140}$ One variable, however, did not receive sufficient consideration in his groundbreaking study: architecture. ${ }^{141}$ My claim is not that architecture can explain the loss of social capital over the past fifty years-this loss has occurred for myriad reasons. But architecture can be part of a solution. It may be a solution at least as effective and realistic as others, such as improving education, insisting on community service, creating familyfriendly workplaces, and trying to increase political participation. ${ }^{142}$

Architecture can prevent crimes even when criminals believe the probability of enforcement is low. The mere fact that architectural solutions expose more criminal activity to public view, even if not ultimately culminating in an official investigation or prosecution, deters because it exposes criminals to the risk of social sanctions. This point is worth emphasizing, as one feature of social norms strategies is that they are often self-enforcing. By giving citizens the power to monitor and intervene in a greater number of crimes, architecture gives a community more autonomy. Such order maintenance would exist in the shadow of the law, so residents would still be able to call the police in case of emergency. But such order contemplates a good deal more discretion-and room for mercy-than standard law enforcement. Norms would often be tailored more appropriately to a given circumstance than would prosecution. ${ }^{143}$

140. $J d$. at 189-283 (examining these explanations).

141. At three isolated places in his book, Putnam makes reference to architectural concepts. At one point, he notes that separatist zoning policies have reduced places for social gathering. Id. at 211. At another point, he refers to Jane Jacobs's invocation of informal networks of neighbors as a constraint on crime. Id. at 308. Finally, his conclusion suggests that the development of "more integrated and pedestrian-friendly areas" and "design of our communities and the availability of public space" can help build social capital. Id. at 408. These concepts are not sufficiently explored, but this is natural for a general and groundbreaking book such as Putnam's.

142. Id. at 404-08, 412-14. Child abuse rates are higher in areas lacking community cohesion. See Jill E. Korbin \& Claudia J. Coulton, Understanding the Neighborhood Context for Children and Families: Combining Epidemiological and Ethnographic Approaches, in 2 NEIGHBORHOOD POVERTY 65, 77-78 (Jeanne Brooks-Gunn et al. eds., 1997). In a study that compared two neighborhoods. Garbarino and Sherman found that parents in a high-abuse community were more afraid to ask for help from neighbors and to swap child-care arrangements with each other. See James Garbarino \& Deborah Sherman, High-Risk Neighborhoods and High-Risk Families: The Human Ecology of Child Maltreatment, 51 CHILD DEv. 188, 192 (1980). They also found that in those communities, "[a] family's own problems seem to be compounded rather than ameliorated by the neighborhood context.... Under such circumstances strong support systems are most needed, but least likely to operate." Id. at 195; see also PUTNAM, supra note 84, at 298-99 (discussing these studies).

143. An early theorist of architecture and crime stated that design "makes possible the development of a social structure by means of which people can create their own social controls, and do their own self-policing." WOOD, supra note 88, at 6 . Heavy presence of law enforcement officers is also costly and imposes a coercive stigma whose taint cannot be easily removed. Such presence can, perversely, spur people to commit crimes as acts of rebellion, particularly in the moments after the police leave a geographic location. 


\section{a. Looking Through Broken Windows}

In their influential article, James Wilson and George Kelling argued that high levels of crime were a response to a breakdown in social order. ${ }^{144}$ The solution to this breakdown, they claimed, was to reform police practices. Wilson and Kelling modeled their conclusions on the basis of a single initiative, the New Jersey Safe and Clean Neighborhoods Program, a program that was only partially about law enforcement. ${ }^{145}$ The slighting of the non-law enforcement features of the New Jersey program is not surprising, given the fact that Wilson and Kelling drew most of their analysis from a Police Foundation study of the program. Legal academics and politicians have thus followed the law-enforcement-centered approach to broken windows and have used its rationale to justify prosecution of quality-of-life offenses (New York City being a prime example of this practice). ${ }^{146}$

This legal approach, however, neglects a central component of the theory behind broken windows, namely, architecture. Wilson and Kelling's real insight was that signs of physical disorder could create fear in lawabiding residents and induce these residents to stay indoors or even move away. Visible signs of disorder may weaken the social norm against crime even further:

A piece of property is abandoned, weeds grow up, a window is smashed. Adults stop scolding rowdy children; the children, emboldened, become more rowdy. Families move out, unattached adults move in....

... [M]any residents will think that crime, especially violent crime, is on the rise, and they will modify their behavior accordingly. They will use the streets less often, and when on the streets will stay apart from their fellows, moving with averted eyes, silent lips, and hurried steps. ... .

Such an area is vulnerable to criminal invasion. Though it is not inevitable, it is more likely that here, rather than in places

144. See Wilson \& Kelling, supra note 5, at 30.

145. The stated purpose of the Act was "to provide State aid to certain municipalities for the purpose of upgrading and augmenting certain municipal services and programs relating to safe and clean neighborhoods." Safe and Clean Neighborhoods Act of 1973, ch. 46, \& 1, 1973 N.J. Laws 103 (formerly codified at 52 N.J. STAT. ANN. \$§ 27D-108 to 27D-1 16) (repealed 1979).

146. See, e.g., Dan M. Kahan \& Tracey L. Meares, Foreword: The Coming Crisis of Criminal Procedure, 86 GEo. L.J. 1153, 1164 (1998) (proposing community policing, antiloitering laws, gang curfews, and other order-maintenance policies). Similarly, Gerald Frug's insightful article considers community policing the primary mechanism to combat fear of crime, and does not focus on other measures. See Gerald E. Frug, City Services, 73 N.Y.U. L. REv. 23, 80-85 (1998). 
where people are confident they can regulate public behavior by informal controls, drugs will change hands, prostitutes will solicit, and cars will be stripped. ${ }^{147}$

Perhaps unconsciously, Wilson and Kelling were following Jacobs's earlier work. Jacobs believed that as crimes happen on a street, people become more afraid of the location and avoid monitoring it. ${ }^{148}$ Thus, a few crimes have the potential to spiral into many-one crime is a complement to another. Unfortunately, Wilson and Kelling converted these thoughts into ones about law enforcement instead of emphasizing the regulation of social order by ordinary citizens. Accordingly, government officials have implemented broken windows as if it were a directive to law enforcement, when its explanatory force is one that radiates far beyond policing.

When Wilson and Kelling arrived on the scene, New Jersey was not restricting its solutions to broken windows to law enforcement reform. Its "safe and clean" legislation was first enacted in 1973 and provided funds for both community policing and programs to reduce urban blight. ${ }^{149}$ In its first year, grants under the "clean" portion were made for additional street lighting, the construction of playgrounds, and the rehabilitation of a community center. ${ }^{150}$ The following year, the program led to the demolition of 446 buildings, construction and refurbishing of thirty parks and recreational facilities, and the purchase of more lighting. ${ }^{151}$ None of these reforms was considered in Wilson and Kelling's account of New Jersey's success in reducing crime. When Wilson and Kelling wrote about New Jersey's success in reducing crime, they explained the phenomenon as a result of policing changes and neglected a crucial environmental variable that had changed during the years they studied. What makes their

147. Wilson \& Kelling, supra note 5 , at 32.

148. See JACOBS, supra note 30 , at 30 ; see also PRESIDENT'S COMM. ON LAW ENFORCEMENT \& ADMIN. OF JUSTICE, THE CHALLENGE OF CRIME IN A FREE SOCIETY 52 (1967) ("People stay behind the locked doors of their homes rather than risk walking in the streets at night. Poor people spend money on taxis because they are afraid to walk or use public transportation. Sociable people are afraid to talk to those they do not know.").

149. Safe and Clean Neighborhoods Act of 1973, ch. 46, 1973 N.J. Laws 103 (formerly codified at 52 N.J. STAT. ANN. §§ 27D-108 to 27D-116) (repealed 1979) (emphasis added).

150. N.J. DEP'T OF CMTY. AFFAIRS, 1974 NEW JERSEY DEPARTMENT OF COMMUNITY AFFAIRS ANNUAL REPORT 31 (1975).

151. N.J. DEP'T OF CMTY. AFFAIRS, 1974-1975 NEW JERSEY DEPARTMENT OF COMMUNITY AFFAIRS ANNUAL REPORT 31 (1976). In 1975, approximately $\$ 12.3$ million was allocated to the "safe" neighborhoods portion of the program, and approximately $\$ 9.5$ million to the "clean" portion. Id. The programs under the "clean" component, such as lighting, construction of public facilities, and demolition of substandard buildings, continued in future years. See N.J. DEP'T OF CMTY. AFFAIRS, 1975-1976 NEW JERSEY DEPARTMENT OF COMMUNITY AFFAIRS ANNUAL REPORT 14 (1977); N.J. DEP'T OF CMTY. AFFAIRS, 1976-1977 NEW JERSEY DEPARTMENT OF COMMUNITY AFFAIRS ANNUAL REPORT 18 (1978); N.J. DEP'T OF CMTY. AFFAIRS, 1978 NEW JERSEY DEPARTMENT OF COMMUNITY AFFAIRS ANNUAL REPORT 19 (1979) (stating that grants were used for "the construction of parks and recreational facilities, trees, litter baskets, public works equipment and a variety of other locally determined priorities"). 
conclusions even more troubling is that the change in this variable was the result of an explicit provision in the exact law about which they wrote. Of course, most people did not draw the connection between the "clean" portion and crime rates. But surely Wilson and Kelling, whose diagnostic work mentions architectural factors such as broken windows and abandoned buildings, set crime policy back by not considering design-based solutions and instead pursuing the single-track focus on law enforcement.

If architecture can help prevent windows from being broken in the first place, then it can accomplish what "broken windows" policing has tried to do, and in ways that may ultimately be better for communities. Quite literally, the use of design tools-such as unbreakable plastic panes instead of breakable glass ones-can reduce the reality and fear of crime. And residents who engage in natural surveillance are most likely to intervene in garden-variety incivilities such as littering, graffiti, and public drinking.

A focus on architecture permits exploration of strategies designed to reduce the fear of crime, a crucial part of Wilson and Kelling's argument. Studies suggest that nearly fifty percent of Americans are afraid to be outside at night in their own neighborhoods. ${ }^{152}$ Fear of crime is not solely the product of the level of crime in a community; studies show that people are more afraid of crime when they see signs of physical disorder around them. ${ }^{153}$ This finding squares with common sense. Most people do not read crime statistics; rather they take cues from the environment. ${ }^{154}$

152. Dan A. Lewis \& Michael G. Maxfield, Fear in the Neighborhoods: An Investigation of Crime, 17 REs. CRIME \& DELINQ. 160, 160 (1980). Women, minorities, and the elderly tend to have a greater fear of crime-a fear that is matched by the reality that they are more often targets of crime as well. Crime Prevention Through Housing Design, supra note 32, at 4; Victoria H. Jaycox, The Elderly's Fear of Crime: Rational or Irrational?, 3 VICTIMOLOGY INT'L J. 329 (1978).

153. Lewis \& Maxfield, supra note 152 , at $162-70$; see also SKOGAN, supra note 22 , at 47 (arguing that physical decay can "spark fear of crime, because Americans have come to associate it with higher levels of risk"); Ralph B. Taylor \& Sally A. Shumaker, Local Crime as a Natural Hazard: Implications for Understanding the Relationship Between Disorder and Fear of Crime. 18 AM. J. COMMUNITY PSYCHOL. 619, 634-35 (1990) (finding a discontinuity between actual and perceived crime rates). Other empirical evidence suggests that people look to environmental cues to assess the safety of a neighborhood. ARTHUR STINCHCOMBE ET AL., CRIME AND PUNISHMENT-CHANGING ATTITUDES IN AMERICA 41 (1980) ("[W]e fear crime . . . in situations that give off danger signs in advance.").

154. Widespread graffiti and abandoned buildings, for instance, have been shown to contribute to the fear and reality of additional crime. See DEP'T OF Hous. \& URBAN DEV., ABANDONED HOUSING RESEARCH (1973) (finding that the abandonment of as little as three percent of buildings in an area can create a tipping point, inducing people to move away and investors to tighten credit); SKOGAN, supra note 22, at 41-43; Lewis \& Maxfield, supra note 152, at 179 (discussing graffiti); John T. Metzger, Planned Abandonment: The Neighborhood LifeCycle Theory and National Urban Policy, 11 HOUSING POL'Y DEBATE (2000), http://www.fanniemaefoundation.org/programs/hpd/pdf/hpd_1101_metzger.pdf (discussing how abandoned buildings increase crime); Terance D. Miethe, Fear and Withdrawal from Urban Life, 539 ANNALS AM. ACAD. POL. \& SOC. SCI. 14, 21 (1995) (noting that "neighborhood deterioration" prompts fear of crime); William Spelman, Abandoned Buildings: Magnets for Crime?, 21 J. CRIM. JUST. 481 (1993) (finding that blocks with abandoned buildings had crime rates twice as high as blocks without them). 
By creating open and inviting areas that can be monitored easily, architects can make residents and bystanders feel safer. ${ }^{155}$ Studies have shown, for example, that darkness in neighborhoods contributes to fear of crime. ${ }^{156}$ Once natural surveillance is enabled through lighting and the variety of other architectural mechanisms discussed above, people will feel more comfortable being out of doors. Sponsoring neighborhood cleanups might be another way to reduce the fear of crime; ${ }^{157}$ indeed, one might wonder whether the recent reduction in crime in New York City is less a result of quality-of-life policing and more a result of the beautification campaigns launched in the city. Creating a sense of territoriality, which has been shown to increase stewardship of the land, can encourage individuals to lead beautification and cleanup campaigns on their own. The claim is not that design will somehow magically transform places of fear into places of frolic, ${ }^{158}$ but that it can help usher in such a transformation.

If architecture can succeed in reducing the fear of crime, it can reduce the actual crime rate even further. This logic follows directly from Wilson and Kelling, who believed that the fear of crime decreases natural surveillance and that natural surveillance in turn helps prevent crime. Fear of crime can undermine the power of natural surveillance for four reasons: (1) It may lead individuals to withdraw from community life; (2) it may imply that attitudes against crime are sufficiently weak that it is not possible to change them; (3) it may undermine the ability of the community to organize itself against crime; and (4) it may harm local businesses, resulting in a poorer economy and less pedestrian traffic. ${ }^{159}$ Studies show that those

155. Bonnie S. Fisher \& Jack L. Nasar, Fear of Crime in Relation to Three Exterior Site Features, 24 ENV'T \& BEHAV. 35, 52-54 (1992); Aldert Vrij \& Frans Willem Winkel, Characteristics of the Built Environment and Fear of Crime: A Research Note on Interventions in Unsafe Locations, 12 DEVIANT BEHAV.: INTERDISC. J. 203, 213 (1991) (finding that "quiet and deserted, poor lighting, good overall view, and actually criminal" are the four "factors that contribute most to the unsafe image of a location").

156. BURSIK \& GRASMICK, supra note 81, at 94-95 (discussing Mark Warr, Dangerous Situations: Social Context and Fear of Criminal Victimization, 68 SOC. FORCES 891 (1990)); see also Crime Prevention Through Housing Design, supra note 32, at 48-49 ("[I]mproved external lighting can help to reduce crime levels and lessen the fear of crime. Effective lighting increases the potential offenders' feeling of exposure and improves the chances of identification and detection.").

157. TAYLOR \& HARRELL, supra note 31 , at 15.

158. See Merry, supra note 38 (criticizing the view that architecture will guarantee that a space will appear safe).

159. BURSIK \& GRASMICK, supra note 81, at 58. Fear of crime ultimately limits "encounters with particular types of people, restrict[s] interpersonal relationships and communications patterns, and reduce[s] participation in particular activities." Miethe, supra note 154, at 22. For example, more than fifty percent of Seattle residents state that they avoid eye-to-eye contact with strangers or stay away from them when they think they are in a "dangerous" area. Id. at 23; see also John E. CONKLIN, ThE IMPACT OF CRIME 99 (1975) ("Crime also seems to reduce social interaction as fear and suspicion drive pcople apart. This produces a disorganized community that is unable to exercise informal social control over deviant behavior."); Skogan, supra note 100, at 215 ("One of the most significant consequences of fear is physical withdrawal from community 
who fear crime are most likely to be withdrawn from public life. And this leads to a multiplier effect: The more people withdraw, the more crime increases; the more crime increases, the more people withdraw. ${ }^{160}$

Architectural solutions can break this dangerous spiral. Take graffiti as an example. Because graffiti increases the fear of crime, architectural techniques that make graffiti more difficult to place on walls may improve a community's morale and bring more people out of doors, thereby reducing the crime rate. The police officer and, more often than not, government officials and policymakers look to the law to prevent graffiti. The architect, by contrast, thinks about graffiti-resistant paints and stains, or careful use of landscaping (planting prickly bushes near walls and the like). ${ }^{161}$ Washington, D.C., has a novel way of preventing graffiti in its Metro transit stations: It uses curved walls that are impossible for passengers to reach and paint. ${ }^{162}$ And even of those architectural solutions that do not directly reduce the crime rate, some will indirectly reduce it by minimizing fear. ${ }^{163}$

life. Fearful people report that they stay at home more often, especially after dark. When they do go out, they carefully avoid coming into contact with strangers.").

160. Bursik and Grasmick note:

If such withdrawal from local networks becomes widespread, the sense of mutual responsibility among the residents is undermined, and those who are able to do so may attempt to physically abandon the neighborhood at the earliest possibility. As a result, the capacity for local control may further deteriorate, thereby accelerating the processes that originally gave rise to crime.

BURSIK \& GRASMICK, supra note 81, at 4-5 (citation omitted); see also SKOGAN, supra note 22, at 49 (" [C]ertain disorders are self-propagating - once they appear, they generate more disorder unless they are quickly and energetically stamped out."); id. at 13 ("Such withdrawal tends to reduce the supervision of youths, undermines any general sense of mutual responsibility among area residents, and weakens informal social control. Withdrawal also undermines participation in neighborhood affairs, presaging a general decline in the community's organizational and political capacity.... Fewer people will want to shop or live in areas stigmatized by visible signs of disorder; these problems feed upon themselves, and neighborhoods spiral deeper into decline.").

161. See CROWE, supra note 18 , at 58 (outlining such solutions); see also BURSIK \& GRASMICK, supra note 81 , at 102 (discussing how the presence of graffiti "clearly illustrates the symbolic implications of disorder").

162. The Washington, D.C., Metro subway system prevents crime through the following: (1) graffiti- and vandal-resistant materials in the trains and on platforms; (2) high ceilings to create feelings of openness and reduce fear; (3) the absence of comers and winding corridors that block visibility; (4) information booths above the platforms so that attendants can watch over them; (5) trash receptacles to reduce litter; (6) plenty of lighting; and (7) clear signs to discourage confusion as riders leave trains, making them less vulnerable to pickpocketing. See Nancy G. La Vigne, Visibility and Vigilance: Metro's Situational Approach to Preventing Subway Crime, at http://www.ismcpi.org/ica/reference/CPTED-1998_10.htm (last visited Nov. 1, 2001).

163. TAYLOR \& HARRELL, supra note 31, at 4 ("Physical improvements may reduce the signals of vulnerability and increase commitment to joint protective activities. Physical deterioration, in all probability, not only influences cognition and behavior of potential offenders but also shapes how residents behave and what they think about other residents."); id. at 14 ("Resident-generated signs of caring and proprietorship signal to other residents and to outsiders that people living there care, are vigilant about what happens on the street, and are willing to intervene if needed." ); Yoko Baba \& D. Mark Austin, Neighborhood Environmental Satisfaction, Victimization, and Social Participation as Determinants of Perceived Neighborhood Safety, 21 ENV'T \& BEHAV. 763, 778 (1989) (making the same point). 
All of this should have been part of the original "broken windows" proposal, but Wilson and Kelling's focus on law prompted politicians, lawyers, and law enforcement officials to neglect architecture and focus on legal enforcement against quality-of-life offenses instead.

\section{b. Architecture as Social Expression}

An ascendant theory in criminal law sees the law as an expression of societal attitudes and beliefs. ${ }^{164}$ This expressive component of the law, it is thought, can deter crime because the law's very enumeration of a set of principles induces compliance. The study of architecture reveals that the statute books are not the only vehicle by which such expressions can be made. The physical environment, too, can be an expression of society's aims and principles-so much so that the expressive power of the environment may even supplant the expressive force of law. After all, architecture is immediately apparent and speaks to those who view it in "an invisible language." 165 As Amos Rapoport has observed, architecture sends nonverbal messages that observers decode. ${ }^{166}$ One cannot understand, say, the Berlin Wall by looking to its technical and physical details; its expressive force dominates these other aspects.

Legal scholars have focused on the relationship between norms and law, reasoning that changing law can change social norms. Some economists, by contrast, have looked to price as a key variable in the formation of social norms. The insight of the expressivist theory of criminal law is to explain how social norms change even when prices are constant. It provides an account for how the law's announcement of principles can shape beliefs. Architects understand that physical space operates in quite the same way, by expressing views that reinforce norms.

Architectural theorists from Heidegger to Harries have singled out architecture's power of expression. To Heidegger, a bridge is not simply a mechanism to bring previously separated locations and people together. It is

164. E.g., Sara Sun Beale, Federalizing Hate Crimes: Symbolic Politics, Expressive Law, or Tool for Criminal Enforcement?, 80 B.U. L. REV. 1227 (2000); Richard H. McAdams, A Focal Point Theory of Expressive Law, 86 VA. L. REV. 1649 (2000).

165. MASAO NOGUCHI, INVISIBle LANGUAGE: A Dialogue WITH Five ARCHITECTS (1991); see also Charles T. GoODSEll, THE SOCIAL MEANING OF CIVIC SPACE 46 (1988) (arguing that architecture is a "teaching medium"); CHRISTIAN NORBERG-SCHULZ, MEANING IN WESTERN ARCHITECTURE 426 (1975) ("[A]rchitecture too is a language.").

166. AMOS RAPOPORT, THE MEANING OF THE BUILT ENVIRONMENT 55-56 (1982); see also MAYA LIN, BOUNDARIES 2:03 (2000) ("Each of my works originates from a simple desire to make people aware of their surroundings, not just the physical world but also the psychological world we live in."); RAPOPORT, supra, at 16-22 (discussing how details like window panes can express certain messages); id. at 28-29 (discussing how the design of Renaissance churches “express[ed] important ideas of neoplatonic philosophy"). 
also a tool of expression. ${ }^{167}$ To Harries, architecture "not only expresses, but intends to express cultural values and concerns. It does not just communicate, it is intended to communicate." 168 Norwegian architect Thomas Thiis-Evensen calls this "architectural expression" and points out how even simple components of a building, such as its floor, wall, and roof, express fundamental beliefs. ${ }^{169}$ Other architects and architectural theorists have also commented on the expressive power of architecture. ${ }^{170}$

Until this point, we have considered the variety of architectural crime prevention techniques as largely equal. Now our path begins to diverge. The expressivist theory of architecture teaches us that architects must be sensitive to the social message sent by design and refrain from using patterns that instill fear. We have already seen signs of this problem, such as dilapidated buildings, which communicate that crime is commonplace, and spaces that are not lit well, which express an attitude of carelessness. For this reason, subtle architecture that gently reinforces law-abiding norms and prevents a degree of intrusion is to be preferred to explicit and awkward physical barricades that reflect the feeling that a community is

167. Heidegger notes:

[P]eople think of the bridge as primarily and really merely a bridge; after that, and occasionally, it might possibly express much else besides; and as such an expression it would then become a symbol .... But the bridge, if it is a true bridge, is never first of all a mere bridge and then afterward a symbol.

Martin Heidegger, Building Dwelling Thinking, in Poetry, Language, Thought 143, 153 (Albert Hofstadter trans., Harper \& Row 1971); see also Gunter A. Dittmar, Architecture as Dwelling and Building Design as Ontological Act, SUBJECT, June 1998, para. 16, at http://www.theo.tu-cottbus.de/wolke/eng/Subjects/982/Dittmar/dittmar_t.html (“[Architecture] locates us within the larger order of our world by 'carving out a place for our being' from the vast and shapeless continuity of time and space and giving it symbolic and physical presence.... Buildings are not ends in themselves, but mediating objects through which we create a world for ourselves and enter into a dialogue with the world around us ...." (quoting Heidegger)).

168. KARSTEN HARRIES, THE ETHICAL FUNCTION OF ARCHITECTURE 285 (1997); see also id. at 157 (noting that "buildings speak to us").

169. ThOMAS ThIIS-EVENSEN, ARCHETYPES IN ARChITECTURE 35, 115, 299 (1987); see also ALEXANDER ET AL., supra note 43 (explaining that architects use a "pattern language" to express certain concepts); Christian Norberg-Schulz, Kahn, Heidegger and the Language of Architecture, 18 OPPOSITIONS 29 (1979) (explaining a similar concept).

170. For Louis Kahn, "the art of architecture is a poetic language. It is nonverbal, consisting of physical ciphers meant to be read. Architecture 'speaks' through silent but evocative, corporeal images directed to the eye." Joseph A. Burton, Philosophical Differences in the Thoughts of Louis A. Kahn and Martin Heidegger, SUBJECT, June 1998, para. 17, at http:/www.theo.tucottbus.de/wolke/eng/Subjects/982/Burton/burton_thtml. James Polshek similarly says that buildings "make public "statements" and can "reinforce the positive aspects of human behavior and thus act as cultural and social stabilizers." JAMES STEWART POLSHEK, CONTEXT AND RESPONSIBILITY 9 (1988). John Zeisel, an architectural sociologist, opines that "[t]he environment is used as a medium of communication: to express individual group affiliation" as well as "to send informal public messages" through, for example, "graffiti on public walls." JOHN ZEISEL, SOCIOLOGY AND ARCHITECTURAL DESIGN 26 (1975).

Not too much should be made of all of this, for many individuals' beliefs are unlikely to be significantly altered by architeclure. The same could be said for the power of the law to change social norms. In both disciplines, expression will change the norms of only some-but this is still significant. 
under siege. Cheap wire fences do not express a belief in the power of law or norms; rather, they reflect the opposite. ${ }^{171}$ The same can be said for ugly iron bars on windows, which express the terror of crime as powerfully as does any sign or published crime statistic.

This insight suggests that certain forms of architectural prevention of crime, particularly cheap barricades, will not capture all potential benefits and may be counterproductive. There are, however, ways to design subtle devices that barricade without reflecting fear. Moreover, a whole host of architectural strategies-such as the placement of doors and windows, creation of semipublic congregation spaces, street layout alterations, park redesign, and many more-sidestep creating an architecture dominated by the expression of fear. Indeed, cheap barricades often substitute for these subtler measures. Viewed this way, gated communities are a byproduct of public disregard of architecture, not a sustainable solution to crime. ${ }^{172}$ Weak

171. Fences must be carefully designed; a cheap one will run the risk of creating a "fortress" mentality and increase the fear of crime. HENRY G. CISNEROS, DEFENSIBLE SPACE 22 (1995); see also Tom McKay, The Target Hardening Trap, at http://www.ismcpi.org/ica/reference/ hard_trap.htm (last visited Nov. 1, 2001) (discussing problems with exclusive reliance on targethardening measures).

172. Gated communities generally work along only one architectural precept-reducing access. They tend to have minimal natural surveillance and poor opportunities for social interaction, thereby creating a false sense of security. See Georjeanna Wilson-Doenges, An Exploration of Sense of Community and Fear of Crime in Gated Communities, 32 ENV'T \& BEHAV. 597, 600, 608 (2000); see also Edward J. Blakely \& Mary Gail Snyder, Divided We Fall: Gated and Walled Communities in the United States, in ARCHITECTURE OF FEAR 85, 97 (Nan Ellin ed., 1997) ("[W]alls, street patterns and barricades that separate people from one another reduce the potential for people to understand one another and commit themselves to any common or collective purpose."); Udo Greinacher, Fear and Dreaming in the American City: From Open Space to Cyberspace, in ARCHITECTURE OF FEAR, supra, at 281, 288-89 (" [G]ated enclaves tend to be nothing more than an assemblage of individuals lacking any communal spirit... [S]tudies conducted by police departments have failed to indicate a decline in property crime due to such elaborate and expensive measures."); Wilson-Doenges, supra, at 605 (summarizing an empirical study showing that the sense of community in gated communities is lower).

In addition, the social meaning of a gated community is one of fear-one that reinforces a view of crime as prevalent rather than controlled. See EDWARD J. BLAKELY \& MARY GaIL SNYDER, FORTRESS AMERICA 152 (1997) ("[G]ated areas ... represent[] a concrete metaphor for the closing of the gates against immigrants and minorities and the poverty, crime, and social instabilities in society at large."). Indeed, gated communities can attract criminals instead of repel them. See John Allman et al., Sense of Security Can Be an Illusion, SUn-SENTINEL, Feb. 25, 2001, at Al (quoting police detective Mike Reed as saying that "some criminals think if it's a gated community, there must be something in there worth getting"). As a result of these factors, empirical studies have found that gated communities do not decrease crime. See id. (discussing a study of fourteen gated and fourteen nongated communities); Jim Carlton, Behind the Gate, L.A. TIMES, Oct. 8, 1989, \& 1, at 3 (describing police department studies in Irvine and Newport Beach, California, that find no reduction in crime in gated communitics); Nan Ellin, Shelter from the Storm or Form Follows Fear and Vice Versa, in ARCHTTECTURE OF FEAR, supra, at 13, 42 (noting studies that show the failure of gated communities to decrease crime); Wilson-Doenges, supra, at 605-07 (discussing a more in-depth study of two communities).

These findings about gated communities do not call into question one of the central conclusions of this Article, which is that a balance among architectural goals is optimal. Some architecture, such as that used by gated communities, may prevent crime at the expense of social interaction. This tradeoff might be worth it in rare circumstances, but a healthy balance among access controls, social interaction, and natural surveillance will often be necessary. Gates alone 
public approaches to crime, whether through law enforcement or other means, stimulate these pernicious methods of self-help.

In sum, we should not underestimate the expressive power of architecture, particularly because law is rather clumsy at shaping social norms. For the law to be truly successful, it actually has to express an attitude that people can hear. And this requires that people know the law or that the expression trickle down through numerous and sometimes improbable filtering agents. ${ }^{173}$ Architecture is, by contrast, a ubiquitous part of life. It does not shape tastes through a reflexive stimulus-response; rather, it operates in nuanced and subtle ways. Careful attention to these pathways is required, for devices that appear to prevent crime can be counterproductive if they express fear.

\section{Individual Attitudes}

Winston Churchill, in defense of rebuilding the House of Commons after the Germans bombed it, stated, "We shape our buildings, and afterwards our buildings shape us." ${ }^{174}$ Churchill understood proxemics and went so far as to claim that the shape of the House was essential to the twoparty system and that its small size was critical for "free debate." 175 Architects can create spaces that bring people together or ones that set them apart. They can reinforce feelings of familiarity and trust or emphasize

will rarely work along the multiplicity of dimensions needed for effective crime control. And a government solution may avoid some of the perverse effects created by the gates, such as suggesting items of value to potential burglars.

173. See Johannes ANDENEAS, PUNISHMENT AND DETERRENCE 110-28 (1974).

174. Winston S. Churchill, A Sense of Crowd and Urgency (Oct. 28, 1943), in 7 WINSTON S. CHURCHILL: HIS COMPLETE SPEECHES, 1897-1963, at 6869, 6869 (Robert Rhodes James ed., 1974). The statement appears to be a variation on Montesquieu's dictum, "[T] republics establish institutions; and afterwards the institutions mold the rulers." MONTESQUIEU, CONSIDERATIONS ON THE CAUSE OF THE GREATNESS OF THE ROMANS AND THEIR DECLINE 25 (David Lowenthal trans., Free Press 1965) (1734).

175. Churchill wanted an "oblong and not semi-circular" Chamber. The latter enables every group to move round the centre, adopting various shades of pink according as the weather changes.... The party system is much favoured by the oblong form of Chamber.... [T] he act of crossing the Floor is one which requires serious consideration. I am well informed on this matter, for I have accomplished that difficult process, not only once but twice.

Churchill, supra note 174, at 6869. He then explained that the Chamber should not be big enough to contain all its Members.... The reason for this has long been a puzzle to uninstructed outsiders .... If the House is big enough to contain all its Members, nine-tenths of its Debates will be conducted in the depressing atmosphere of an almost empty or half-empty Chamber. The essence of good House of Commons speaking is the conversational style .... But the conversational style requires a fairly small space....

Id. at 6870 
harshness and social chaos. Sociological and psychological work confirms the impact of design on behavior and attitudes. ${ }^{176}$

The theory of how architecture shapes tastes has been developed within the field of environmental psychology and has been largely ignored by law schools due to their focus on the use of legal codes to regulate conduct. ${ }^{177}$ The general upshot of this work is that architecture can alter human behavior. Many of these influences occur on a subliminal level, and their effects are not always "thought out." ${ }^{178}$ For example, when individuals walk into a room, they will be cued by features of the room-whether it is occupied (and to what extent), whether it is furnished (and in what manner), and so on. Some of these features will be consciously noticed, others will not. But the unconscious ones can influence behavior and attitudes too, as evidence from psychiatric wards, prisons, and elsewhere reveals. ${ }^{179}$

Caution about these experimental findings is warranted, for architecture is only one variable in the mix of stimuli that influence individual behavior. But these findings are not newfangled ones; indeed, the belief that architecture changes attitudes is at least as old as Western civilization. The ancient Greeks designed their temple columns with stone bearing large traces of phosphorus because they knew it would throw off a golden glow after dawn and dusk, reminding people to come to the temple and commanding awe. ${ }^{180}$ Castles were built with moats, not simply to make penetration more difficult, but also to set the castle off from the rest of the land and induce reverence among viewers. Today, law enforcement is aware of the power of architecture when it comes to questioning suspects. The interrogation room is a study in architectural manipulation; its large desks, tables, and high chairs for interrogators and bright lighting simulate the effect of a truth chamber.

In addition to influencing social interaction, ${ }^{181}$ architecture can influence behavior and attitudes more directly through design. For example,

176. E.g., HALL, supra note 120 , at 171 (emphasizing that "virtually everything that man is and does is associated with the experience of space"); WILLIAM MiCHELSON, MAN AND HIS URBAN ENVIRONMENT 30-32, 168-90 (1970) (discussing studies).

177. ROGER G. BARKER, ECOLOGICAL PSYChOLOGY 186-205 (1968); ITTELSON ET AL., supra note 2, at 1, 5-6, 343.

178. ITTELSON ET AL., supra note 2, at 13, 128.

179. See Daniel Glaser, Architectural Factors in Isolation Promotion in Prisons, in ENVIRONMENT AND THE SOCIAL SCIENCES, supra note 97, at 105 (discussing prisons); William $\mathrm{H}$. Ittelson et al., Bedroom Size and Social Interaction of the Psychiatric Ward, in ENVIRONMENT AND THE SOCIAL SCIENCES, supra note 97, at 95, 99-104 (discussing psychiatric wards); see also CONSTANCE PERIN, WITH MAN IN MIND 36 (1970) ("The physical environment is said to influence social and interpersonal relationships ... [and] can maximize human interaction."); Alberto Pérez-Gómez, Dwelling on Heidegger: Architecture as Mimetic Techno-Poiesis, SUBJECT, June 1998, at http://www.theo.tu-cottbus.de/wolke/eng/subjects/982/perezgomez_t.html (discussing the scientific impact of architecture).

180. Crowe, supra note 18 , at 82 .

181. I have already shown how providing residents with some dominion over public spaces, even through minor measures such as permitting gardening on public property, can prevent crime 
the feeling of being crowded correlates with aggression. ${ }^{182}$ Architects can alleviate the sensation of crowding by adding windows that allow for natural light, by using rectangular rooms (which are perceived to be larger than square ones), and by employing light-colored paints. ${ }^{183}$ When people perceive more space, they tend to become less hostile. Apart from these positive effects, light and dark have other effects on human behavior that may be relevant to crime. ${ }^{184}$ Other techniques, such as incorporating nature and greenery, have also been shown to decrease aggressive behavior. ${ }^{185}$

While the studies should not be overemphasized, psychologists have found results showing that various colors affect behavior and emotions. The most consistent such finding is that red induces a higher level of arousal than do cool colors like green and blue. ${ }^{186}$ Another study indicated that

by giving people incentives to take care of their property and monitor nearby individuals. Such strategies also reinforce a crucial lesson: People can manipulate the environment around them. Incentives for individual control can encourage good neighboring and watchful eyes and can suggest to criminals that they cannot rationalize away their criminal acts. JACOBS, supra note 30 , at 82 (contrasting a locksmith who "bawls out one of my sons for running into the street" with an unrescued boy trapped in a housing project elevator; the former receives "an overt lesson in safety and obedience" and the indirect lesson that the locksmith, "with whom we have no ties other than street propinquity, feels responsible for him," whereas the latter "learns opposite lessons from his experiences"); NEWMAN, supra note 26, at 206 (making a similar point).

182. See Andrew Baum \& Paul B. Paulus, Crowding, in 1 HANDBOOK Of ENVIRONMENTAL PSYCHOLOGY 533, 533-70 (Daniel Stokols \& Irwin Altman eds., 1987).

183. See Andrew Baum \& Glenn E. Davis, Spatial and Social Aspects of Crowding Perception, 8 ENV'T \& BEHAV. 527 (1976) (discussing light-colored rooms); David R. Mandel et al., Room Utilization and Dimensions of Density: Effects of Height and View, 12 ENv'T \& BEHAV. 308, 309 (1980) (finding that rooms exposed to light are perceived as less crowded); Edward K. Sadalla \& Diana Oxley, The Perception of Room Size: The Rectangularity Illusion, 16 ENV'T \& BEHAV. 394 (1984) (discussing rectangular rooms); see also Naz Kaya \& Feyzan Erkip, Satisfaction in a Dormitory Building: The Effects of Floor Height on the Perception of Room Size and Crowding, 33 ENV'T \& BEHAV. 35 (2001) (discussing floor height).

184. Consider one study that put eight people each (four men and four women) in two rooms without their shoes or anything in their pockets. One room was lit and one completely dark. In the lit room, the subjects spoke in polite conversation the entire time, tended to sit in one spot, and barely touched each other. However, in the dark room where subjects were told they would not meet each other in the light, $100 \%$ of the subjects accidentally touched each other, $90 \%$ intentionally touched each other, $50 \%$ hugged, some even kissed, and almost $80 \%$ reported feeling some degree of sexual excitement. Kenneth J. Gergen et al., Deviance in the Dark, PSYCHOL. TODAY, Oct. 1973, at 129-30; see also Roger Ulrich, View Through a Window May Influence Recovery from Surgery, 224 SCIENCE 420, 421 (1984) (finding that patients with views of nature outside windows had shorter post-operative stays).

185. See Stephen Kaplan, The Restorative Benefits of Nature: Toward an Integrative Framework, 15 J. ENVTL. PSYCHOL. 169 (1995) (concluding that experience in natural environments mitigates stress); Frances E. Kuo, Coping with Poverty: Impacts of Environment and Attention in the Inner City, 33 ENV'T \& BEHAV. 5 (2001) (suggesting that the addition of greenery would enhance the functioning of public housing residents); Frances E. Kuo \& William C. Sullivan, Environment and Crime in the Inner City: Does Vegetation Reduce Crime?, 33 ENV'T \& BEHAV. 343 (2001) (finding that the greener a building's surroundings are, the fewer total crimes occur).

186. See Glenn D. Wilson, Arousal Properties of Red Versus Green, 23 PERCEPTUAL \& MOTOR SKILLS 947 (1966). In one study of psychiatric wards, cool colors were found to induce patients to be calmer and have higher self-esteem, and reduced the number of violent outbreaks. 
people walked faster down a hallway painted red or orange than down one painted in cooler colors. ${ }^{187}$ After experimenting with hundreds of shades, Professor Schauss identified a certain shade of pink, Baker-Miller, as the most successful color to mediate aggression. ${ }^{188}$ The shade has been tested multiple times with strong results tying it to decreased aggression. In one recent study, prisoners in Baker-Miller pink cells were found to be less abusive than those in magnolia-colored cells. ${ }^{189}$ Some members of the scientific community remain unconvinced by such findings, and hesitation is warranted before changing design along these lines.

None of this should be mistaken for architectural determinism or its derivative belief that good buildings alone will end crime. These hopes of "salvation by bricks" are illusory. ${ }^{190}$ But our rejection of this extreme should not lead us to the opposite extreme view, which holds that physical settings are irrelevant to human beliefs and action. Architecture influences behavior; it does not determine it.

\section{Perpetration Cost}

Architecture can also constrain crime by making it more expensive, as this monetary price will deter some offenders. This point can be summarized briefly. When target-hardening measures and access controls are employed, only those criminals who have the sophistication and tools to circumvent these defenses will be frequent violators. Strong locks on doors, for example, require training and equipment to break. Some empirical evidence suggests that burglars are sensitive to fences and locks; one reason is that such devices increase the cost of committing a criminal act. ${ }^{191}$ Prominent criminologists have argued that crime is a result of a need for

Roger Christenfeld et al., How Physical Settings Affect Chronic Mental Patients, 60 PSYCHIATRIC Q. 253, 262 (1989).

187. See Richard Seaton, DeP'T OF Architecture, Univ. OF Cal., Berkeley, MisCELlanEOUS UNDERGRADUATE RESEARCH ON SPATIAL BEHAVIOR 18 (1968).

188. See Alexander G. Schauss, The Physiological Effect of Color on the Suppression of Human Aggression: Research on Baker-Miller Pink, at http://bacweb.the-bac.edu/ -michael.b.williams/baker-miller.html (last visited Nov. 1, 2001).

189. See C.P. Bennett et al., The Use of Baker-Miller Pink in Police Operational and University Experimental Situations in Britain, 13 INT'L J. BIOSOCIAL \& MED. RES. 118, 121 (1991) (noting that "statistical analysis produced a $95 \%$ probability that the pink cell would tranquilize subjects quicker than a magnolia cell"); see also James E. Gilliam, The Effects of Baker-Miller Pink on Physiological and Cognitive Behaviour of Emotionally Disturbed and Regular Education Students, 17 BEHAV. DISORDERS 47 (1991).

190. JACOBS, supra note 30, at 113 (quoting Reinhold Niebuhr). For example, Buckminster Fuller, the engineer who invented the geodesic dome, stated, "I have learned to undertake reform of the environment and not to try to reform Man. If we design the environment properly, it will permit child and man to develop safely and to behave logically." Buckminster Fuller, What I Have Leamed: How Little I Know, SATURDAY REV., Nov. 12, 1966, at 70.

191. Barbara B. Brown \& Irwin Altman, Territoriality, Defensible Space and Residential Burglary: An Environmental Analysis, 3 J. ENVTL. PSYCHOL. 203, 216 (1983). 
immediate gratification; " $[t]$ hus a locked door will prevent some burglary. A locked door that cannot be smashed without mechanical aid will prevent more. A residence that appears to be observed by neighbors will be less vulnerable than a residence that cannot be seen by people living in the area." 192

The employment of natural surveillance and other strategies may force criminals to work in teams and to hire lookouts and procure firepower to avoid detection and capture. Such conspiracies, in addition to increasing the severity of punishment, require the criminals to split profits and increase capital investment. All of this can make crime less attractive to the criminal by increasing the perpetration costs and reducing the potential gain. ${ }^{193}$ In addition, if individuals commit crimes despite the higher perpetration cost, that cost might produce "income effects" that reduce the frequency of entirely unrelated crimes. ${ }^{194}$ Imagine a house burglar's reaction to the installation of doors that require sixty minutes to break down instead of thirty. Some burglars will refrain from the crime altogether due to the high labor cost (a form of cost deterrence); others will still break down doors, but will not have the time to commit other crimes (due to the income effect). This aspect of deterrence becomes easier to understand when "cost" is viewed not only as legal risk, but as a variable involving capital and labor inputs.

\section{METHODS FOR THE GOVERNMENT TO HARNESS ARCHITECTURE}

Government can promote architectural answers to crime, but the task is not an easy one. We face three sets of difficulties here. One set of problems has to do with teaching architects about crime control. As a discipline, architecture does not devote much attention to crime, instead focusing primarily on ornament, function, and more traditional matters of design. A second set of problems has to do with criminal lawyers, who tend to think retrospectively, in terms of particular offenses, specific offenders, individual culpability, and purely legal remedies. A third set of problems arises from the harm inflicted by aggressive forms of architectural control. As I discuss in Part III, the use of architecture can be costly, may undermine privacy and individual freedom, and may displace crime to other locations. All three sets of problems are compounded by the fact that U.S. land-use law is tremendously decentralized.

The methods proposed in this Part are not full "solutions" to these difficulties, for these problems will persist in some form. Yet pessimism is

192. GOTTFREDSON \& HIRSCHI, supra note 24, at 28.

193. See Neal Kumar Katyal, Conspiracy Theory (n.d.) (unpublished manuscript, on file with author) (arguing that conspirators can increase the perpetration cost of crime).

194. See Katyal, supra note 4, at 2432-34 (discussing income effects and $y$-optimality). 
not becoming either, for rules can be structured to encourage architects and landowners to think about humanistic forms of crime control. Particularly in those settings in which conventional crime-control proves ineffective or too costly, more attention to architecture can be beneficial. To pluck out five quick examples: (1) Governments could promote crime-control mechanisms in their own construction and planning, thereby teaching architects and private landowners by example; (2) governments could require developers to submit "Crime Impact Statements" whenever they embark on major projects and could thus lead architects and schools of architecture to focus on crime prevention; (3) legislators could launch systematic attempts to reform the model building codes in order to stress crime control; (4) courts and legislators could strengthen already-existing tort liability for poor architectural design to turn insurance companies into educators about crime prevention; and (5) law enforcement agencies could use criminal regulation of architecture, through forfeiture and other methods, to eliminate recidivist locations.

As I discuss in the following Section, fire prevention provides a useful model. Historically, the prevention of fire through architecture ran into many of the same problems: Architects did not tend to think in such terms, and decentralization of land use made legal reform quite difficult. Yet effective fire prevention eventually succeeded, largely because private insurance companies stepped in to become fire-prevention educators. Fire prevention codes, many of which were written by insurance companies, also played a significant role in encouraging localities to adopt adequate safeguards. ${ }^{195}$ So the task is difficult, but not impossible. The pages that follow sketch out an analytical and practical framework for harnessing architecture, focusing on three distinct government roles: government as builder, as regulator, and as enforcer. Even if governments decide not to follow these suggestions, knowledge about the intersection between architecture and crime can help law enforcement predict where crime might take place. ${ }^{196}$ 285.

195. See S.S. HUEBNER, PROPERTY INSURANCE 368 (1938); infra text accompanying note

196. As changes to the physical environment-such as an increase in the number of "for rent" signs and abandoned buildings - become apparent, law enforcement officers can adjust their priorities in anticipation of an increase in crime. TAYLOR \& HARRELL, supra note 31, at 19 ("Physical changes appear to precede crime changes.... [R]esearchers found that patterns of owner-to-rental conversion, land use changes, and abandonment predicted the emergence of hardened high-crime areas."); Ralph B. Taylor \& Jeanette Covington, Ecological Change, Changes in Violence, and Risk Prediction, 5 J. INTERPERSONAL VIOLENCE 164, 172-74 (1990) (discussing how crime prediction can vary by dynamic neighborhood characteristics); Sherry Plaster Carter, Neighborhood Warning Signs-CPTED to the Rescue-Part 2: Expanded CPTED Strategies, at http://www.ismcpi.org/ica/reference/CPTED-1998_06b.htm (last visited Nov. 1, 2001) (describing similar architectural features that predict crime increases). Some have suggested that the predictive power of architecture can be used to facilitate rapid intervention by government when an area is about to turn into a high-crime one. E.g., Leo Schuerman \& Solomon Kobrin, 


\section{A. Government as Builder}

\section{Housing}

Several problems with modern housing projects have already been covered, such as the height of the buildings, the design-induced feelings of isolation, and the destruction of territoriality. Many of our nation's children are raised in public housing; if architecture can foster social interaction and anticrime attitudes among adults, such lessons similarly may be impressed upon children.

Current federal regulations require public housing to conform to building codes, national fire prevention standards, and the mandates that projects "promote security" and "harmonize with the neighborhoods they occupy." 197 Government can strengthen these regulations by incorporating an explicit crime prevention focus. Building public housing that incorporates crime prevention principles will help the effort to reduce other social ills $\mathrm{s}^{198}$ and can be done at costs equivalent to or less than those for existing projects. ${ }^{199}$

In particular, government regulations could require consideration of the architectural goals discussed in Part I. Empirical evidence, such as Oscar Newman's study of 100 New York City housing projects, supports such

Community Careers in Crime, 8 CRIME \& JUST. 67, 99 (1986) (suggesting that government can react by increasing foot patrols, enforcing building codes more strictly, and carefully making zoning decisions).

Furthermore, regardless of whether government uses architectural strategies, criminals will. Lawbreakers currently change the environment to make their activity less visible, for example, by employing mechanisms to slow down the entry of police officers into areas of crime and by picking places to conduct their activity that facilitate easy escape. See Randall Atlas, The Other Side of CPTED, SECURITY MGMT., Mar. 1991, at 63, 65-66 (finding such phenomena in Florida).

197. 24 C.F.R. $\S 941.203$ (2001). In addition, regulations also suggest that families with children should not be housed in elevator buildings. Id. $\$ 941.203(\mathrm{~d})$.

198. For example, poor architectural design can reinforce racial stereotypes in two ways. First, specific knowledge can act as a barrier to discrimination. If an entryway to a housing project is used by a few families, each of them will have the opportunity to know the others and will have a strong ability to detect unwanted outsiders, of whatever race. By contrast, large projects where hundreds of users pass in and out do not afford the same sort of protection. Instead, those individuals who are stopped by residents may be disproportionately minorities, because of unconscious or conscious racial profiling. Second, people who fear crime are generally more likely to adopt odious general profiles of what a culprit "looks like," reasoning that the end of preventing some crime justifies the racist means.

199. Such costs, moreover, should not be assessed in a vacuum, for the use of architectural strategies confers positive externalities on society by reducing the crime rate. This reduction in crime, in turn, reduces the amount spent on law enforcement and prisons and increases property values. See generally CROWE, supra note 18, at 214 (explaining why revitalization of cities can be done without huge expense); GARDINER, supra note 30, at 58-60 (arguing that architectural solutions to crime are cost-effective); MOE \& WILKIE, supra note 66, at xiii, 142-238 (arguing that revitalization of cities is cost-effective). And as Hassan Fathy's groundbreaking work about Egyptian planning demonstrates, architects can work within even severe cost constraints to develop workable plans that take advantage of local supplies and labor markets. HASSAN FATHY, ARCHITECTURE FOR THE POOR (1973). 
reforms. ${ }^{200}$ Newman found that large housing projects "encourage crime by fostering feelings of anonymity, isolation, irresponsibility, lack of identity with surroundings, etc." ${ }^{201}$ By strategically placing housing units, windows, corridors, and entryways in areas that provide natural surveillance, design protects both inhabitants and passersby-who will then venture out in public more and draw additional people to the area. Accordingly, the recent trend away from high-rise housing projects should be encouraged. Onethird of the 1.4 million units of public housing are already one- and twostory structures, and buildings from three to six stories comprise almost another quarter of the units. ${ }^{202}$ Paying more attention to exterior environments is also important. Bulk uniform projects stigmatize residents and suggest that they are "easy hits." 203

For some existing housing projects, the government could pass regulations requiring retrofitting to prevent crime. Small private or semiprivate lawns near entrances can encourage feelings of territoriality; strong lighting can enhance visibility; staining and glazing can increase contrast; and buildings refaced with a diversity of pleasing finishes can reflect individuality and territoriality. Large open spaces can be subdivided to encourage natural surveillance. If teenagers are a crime problem, architects can create rough-appearing areas for them to congregate, for

200. See NEWMAN, supra note 26, at 27. Newman's work has been criticized on methodological grounds. Merry, supra note 38; A.E. Bottoms, 14 BRIT. J. CRIMINOLOGY 203, 205-06 (1974) (reviewing NEWMAN, supra note 26) (criticizing Newman's methodology but stating that his thesis is plausible). Other studies have corroborated his findings, however. Taylor, supra note 81 , at 305 (citing other studies and concluding that "the focus on design as a covariate of crime has been substantiated"). Studies have also corroborated the theory of defensible space:

Defensible space theory has received strong supporting evidence from studies of public housing in Britain and the United States and from studies of residential street blocks in the United States. What many consider to be one of the strongest studies focused on 63 public housing sites around the country. The study found that sites with more defensible space features had residents who better controlled outdoor spaces and were less fearful and less victimized.

TAYLOR \& HARRELL, supra note 31 , at 8.

201. NEWMAN, supra note 26 , at 28 . Tall projects often achieve no greater housing density than low-rise buildings, are more expensive, and facilitate crime and social isolation. Architects took the high-rise concept from middle- and high-income buildings and simply copied it for housing projects. But the formula of using a single entrance and elevator bank only works well in conjunction with features that exist in upper-income buildings, such as a doorperson or security guard. See id. at 23-24. Once the city of New Orleans switched from using large buildings with interior stairs and corridors to using smaller two- and three-story walk-ups as housing projects, for example, the robbery rate plummeted and burglaries of apartments were virtually eliminated. $I d$. at 100 . The result of such tactics is to "cement collective identity and responsibility ... through these social pressures[;] . . . opening up all activity in public spaces to natural supervision proves a very powerful deterrent to criminal acts." Id.

202. CISNEROS, supra note 171 , at 9 .

203. NEWMAN, supra note 26, at 102; see also ITTELSON ET AL., supra note 2, at 268 ("The house is a symbolic extension of oneself; as such, its character (slum or mansion) may be the result of personal qualities (inadequacy or skill) as well as a reinforcer of those qualities. With many poor families the housing-poverty cycle is, indeed, a vicious one."). 
example, by using uncut stone slabs for sitting and placing the stones near streets and apartments for natural surveillance. ${ }^{204}$

Clason Point Gardens in the South Bronx provides a helpful example of how to retrofit existing projects. Architects made four simple changes to these row houses to reduce the crime rate: They (1) placed attractive sixfoot iron fencing in the back of the row houses; (2) created paths and low curbs in the front of each unit to demarcate the front yard of each row house as individual property; (3) resurfaced the uniform building façades in different colors and textures to differentiate each unit; and (4) used street lighting and seating areas in public spaces to encourage people to be outside. Within one year, residents had begun to care for the areas in their front and back yards; almost all of them planted grass seed, and many planted shrubs. After the measures, the overall crime rate dropped by more than fifty percent. In addition, nearly twice as many tenants felt comfortable questioning strangers who were present on the grounds. ${ }^{205}$

There are, however, other projects for which there is only one solution: razing them. Very poorly designed buildings-which tend to be tall, with single entrances and bleak, uniform appearances-are not likely to become vibrant or to attract law-abiding tenants. Federal law already permits projects to be destroyed when crime is rampant, and many cities have done so. ${ }^{206}$

Instead of rebuilding projects, the federal government has encouraged some tenants to take rent subsidies through programs such as "Section 8." Just as with public housing projects, government can issue procurement regulations to govern the architectural safety of such apartments. Landlords

204. NEWMAN, supra note 26 , at $172-73$. In addition, projects should be placed away from highways (thereby preventing casy cscape), avoid low windows (permitting entry into units by persons and bullets), and avoid footpaths with winding trails and dense shrubs.

205. CISNEROS, supra note 171 , at 10.

206. See 42 U.S.C. \$ $1437 \mathrm{v}$ (1994) (permitting demolition of housing projects when a project "has high rates of vandalism and criminal activity (including drug-related criminal activity) in comparison to other housing in the area"). The Federal HOPE VI program administers grants for revitalization and demolition of projects as well. See Harry J. Wexler, Hope VI: Market Means/Public Ends-The Goals, Strategies, and Midterm Lessons of HUD's Urban Revitalization Demonstration Program, 10 J. AfFoRdable HousING \& COMMUNITY DEV. L. 195, 196-98 (2001); see also Elizabeth Benjamin, Crime Rate Falls for Public Housing, TIMES UNION, Sept. 3, 2000, at $\mathrm{Cl}$ (discussing the destruction of Edwin Corning Homes in Albany); Christopher Burbach, Putting Pride in the Heart of the City, OMAHA WORLD-HERALD, May 11, 2001, at 1 (discussing the tear-down of Logan Fontenelle projects in Omaha "in an effort to decentralize crime-plagued public housing"); William Claiborne, HUD, Chicago Ink Deal To Reconstruct Public Housing, WASH. POST, Feb. 6, 2000, at A2 (discussing the destruction of Chicago's Robert Taylor Homes, which were "crime-plagued and drug-ridden"); Metro in Brief, WASH. POST, July 4, 1999, at C3 (stating that George B. Murphy Homes in Baltimore were torn down because they were "crime and drug-infested"); Norm Parish, Darst-Webbe's Replacement Will Be Different, ST. LOUIS POST-DISPATCH, May 16, 2001, at B1 (discussing the destruction of the Darst-Webbe project in St. Louis, which was "(roubled by years of decay and crime"); Rena Pederson, To Tame a Tough Neighborhood Take a Stroke from Tiger Woods, PROVIDENCE J., Jan. 13, 2001, 2001 WL 5372435 (discussing the tear-down of the East Lake Meadows project in Dallas). 
who have Section 8 tenants must already meet certain standards, such as providing "lockable" exterior doors and windows, garbage facilities, and kitchens with food storage space and sinks. ${ }^{207}$ Crime prevention, however, could be a more explicit focus of the regulations governing rent-subsidized housing. Approximately 3.7 million Americans currently receive these rent subsidies from the government, ${ }^{208}$ so the power of such a regulation to change the architecture of private apartments would be vast and might impress these methods upon private builders as well.

\section{Public Lands}

City streets and sidewalks account for about one-quarter of developed urban land, ${ }^{209}$ and governments own a plethora of buildings and parks. Accordingly, governments' attention to crime prevention on their own lands holds significant promise in controlling crime. Governments can also transmit these techniques to the private sector by instructing architects and construction firms in effective design.

Governments may redesign city streets to reduce crime in a variety of ways. Consider five possibilities. First, because streets and sidewalks constitute large amounts of land in cities, greater attention to lighting those areas would deter crime substantially. Second, localities could alter the placement of bus stops and other public transit facilities so that they are not near alleys and other easy escape routes. ${ }^{210}$ Third, by using attractive barriers, localities could selectively close streets with high crime and easy escape routes and mark them as "no through street" or "dead end." ${ }^{211}$

207. 24 C.F.R. $\$ 982.401$ (c), (d) (2001). The local housing authority must inspect a unit both prior to occupancy by a Section 8 tenant and at least on an annual basis. $I d . \S 982.405$. With Section 8 , the government is not acting as a builder, but rather as a quasi-regulator. This Article considers Section 8 here because the govemment is a market participant, and the methods follow naturally from the analysis of crime prevention in housing projects.

208. U.S. DEP'T OF HOUS. \& URBAN DEV., A PICTURE OF SUBSIDIZEd HousING IN 1998 (1998), http://www.huduser.org/datasets/assthsg/statedata98/index.html. To the extent such costs will be passed onto tenants, government could provide tax breaks or other sources of funding to defray the cost. See infra Subsection II.A.3.

209. Robert C. Ellickson \& Vicki L. BeEn, LAND USE CONTROLS 15 ( $2 \mathrm{~d}$ ed. 2000).

210. A recent study of 1480 crimes at sixty different bus stops in Los Angeles found that over one-half of the crimes were committed at six stops. Anastasia Loukaitou-Sideris et al,, Measuring the Effects of Built Environment on Bus Stop Crime, 28 ENV'T \& PLAN. B: PLAN. \& DESIGN 255 (2001). The location of the bus stop was found to be a critical factor in predicting the crime rate; for example, those bus stops near porous alleys had crime rates that were approximately double those of stops not near alleys. Id. at 267. Bus stops near vacant lots also had crime rates at least double those of stops not near such lots. Id. at 270.

211. When Dayton, Ohio, employed selective closures in the Five Oaks neighborhood after the neighborhood had become known for a burgeoning drug and prostitution trade, the crime rate plummeted. The city adopted an architectural plan that divided the one-half-square-mile area into ten mini-neighborhoods. Each mini-neighborhood consisted of three to six streets and shared similar housing styles. Streets were then closed off strategically, so that only one portal could be used to enter each of the ten mini-neighborhoods. The other entrances were blocked with iron 
Fourth, to increase natural surveillance, trees or other vegetation could be placed alongside streets to make them more attractive, and street cleaning and sidewalk repair can be made regular. ${ }^{212}$ Building benches and permitting inner-city gardening on public land would further draw people outdoors. ${ }^{213}$ Fifth, communities could expand the use of traffic control devices (such as neighborhood signs, rumble strips, chokers, bumps, and traffic circles) and traffic restrictions (technological enforcement of neighborhood low speed limits, truck and bus restraints, turn prohibitions, and parking controls) to increase foot traffic and slow down escapes. ${ }^{214}$

A full discussion of these alternatives must await another time. But one illustration is illuminating: the Dutch woonerf, or "residential yard." By repaving streets and displaying signs, woonerf developers make streets fully available for pedestrians, as well as cars, and provide the " 'gestalt' message that the street belongs to the residents." ${ }^{215}$ The upshot of the woonerf is to increase contact between drivers and pedestrians, slow traffic down, create a residential atmosphere, and "emphasize the street as a 'place' rather than a "channel." 216 The woonerf illustrates some of the creative possibilities for already-existing streets.

gates that could be unlocked in emergencies. The design made it difficult for criminals to escape quickly and stimulated a sense of common identity within the mini-neighborhoods. Cheap gates and high walls that excluded pedestrians were eschewed out of a belief that they would create fear rather than drive it away. CISNEROS, supra note 171, at 21-22; see also David Holmstrom, Gates in Dayton Fortress a Diverse Neighborhood, ChristIAN SCI. MONITOR, July 31, 1995, at 12 (describing the program); Ingrid Padgett, Neighborhood Stabilization Works for Dayton Community, NATION'S CITIES WKLY., Sept. 5, 1994, at 3 (same). In total, thirty-five gates were set up and twenty-six alleys were closed, at a cost to the city of under $\$ 700,000$.

"The effect was dramatic and immediate. Between 1992 and 1993, nonviolent crime in Five Oaks fell by 24 percent and violent crime by 50 percent. ... The average price of a single-family home in the area increased over the same period by 15 percent." CISNEROS, supra note 171, at 19; see also Dina Bunn, Council Studies Street Gates, Rocky MTN. News, May 2, 1995, at 18A (discussing the benefits of gates in Dayton, Miami Shores, Detroit, and St. Louis). The street closures "made it impossible for drug dealers and their clients to operate there, because if you came in to buy drugs and the cops came or someone reported you, you had to go back the way you came in. You didn't have three or four different exit routes. That stopped the drug dealing." All Things Considered: The Case for Gated Communities (NPR radio broadcast, Apr. 1, 1995).

212. APPLEYARD ET AL., supra note 39, at 66-67, 253.

213. TAYLOR \& HARRELL, supra note 31 , at 15 ("The garden gives them a reason to keep an eye out on the street and involves them more in the neighborhood."); see also Tom McKay, Empty Spaces, Dangerous Places: Crime Prevention Through Environmental Design Reference Materials, at http://www.ismcpi.org/ica/reference/empty_space.htm (last visited Oct. 19, 2001) (discussing how urban gardens planted over vacant lots make an area safer). Such gardening can also facilitate social interaction. Paul E. Greenbaum \& Susan D. Greenbaum, Territorial Personalization: Group Identity and Social Interaction in a Slavic-American Neighborhood, 13 ENV'T \& BEHAV. 574, 587 (1981).

214. APPLEYARD ET AL., supra note 39, at $80,253,296-305$; see also County Bd. v. Richards, 434 U.S. 5, 7 (1977) ("A community may also decide that restrictions on the flow of outside traffic into particular residential areas would enhance the quality of life there by reducing noise, traffic hazards, and litter.").

215. APPLEYARD ET AL., supra note 39 , at 250.

216. Id. at 250, 308; see also Eran Ben-Joseph, Changing the Residential Street Scene: Adapting the Shared Street (Woonerf) Concept to the Suburban Environment, 61 J. AM. PLAN. 
In addition to improvements in street planning, crime prevention requires better public park design. A park that is rarely used is like a street without neighbors - a place for crime to fester. Yet many city planners insist that building additional parks and open spaces is the solution to urban ills. As Jane Jacobs once asked, "More Open Space for what? For muggings?" 217 Park design should follow the architectural precepts discussed in Part I, such as building long and thin parks that permit observation at every point. Parks should also have visible and well-marked entrances and exits, level land, effective lighting, the absence of hidden spaces, and high maintenance levels. ${ }^{218} \mathrm{~A}$ former top prosecutor has told me that drug dealers in Washington, D.C., prefer to sell their wares in the center of city parks over most all other locales because there they can see the police coming and easily run in any direction. ${ }^{219}$ Therefore, low fences and symbolic barriers should be used to preclude multiple exits.

In the 1970s, New York City's Bryant Park, located next to the Public Library in midtown Manhattan, was commonly called "Needle Park." Needles littered the ground, and prostitutes used the tall grasses to conduct transactions. Law-abiders, both children and adults, avoided the park. Crime flourished, in part because of the park's architecture; "design, rather than sociology, was at the root of Bryant Park's problems." 220 The park contained hidden areas conducive to criminal activity and its design reduced the circulation of users. ${ }^{221}$ It was surrounded by a high granite wall and dense tree growth, both of which interfered with natural visibility. ${ }^{222}$

The City of New York redesigned the park in order to reduce crime. The new design was faithful to the park's original Victorian architecture, but altered the topography to make all areas of the park visible. Secluded spaces were eliminated; shrubs that interfered with visibility were removed. The city created seating areas, permitted food kiosks, and erected a stage for concerts. Drug dealing and other crimes dropped dramatically (the

Ass' $N 504$ (1995) (arguing that the success of the shared street concept in Europe. Japan, and Israel suggests its adaptability to U.S. suburbs).

217. JACOBS, supra note 30 , at 90.

218. See William H. Whyte, The Social life of Small Urban SPaces 10-59 (1980) (documenting features that make parks and plazas more accessible and inviting, including appropriate length of steps, small increases in ledge space, placement of such spaces within sightlines, and other design features); DEBORAH HIERLIHY, CITY OF TORONTO PLANNING \& DEV. DeP'T, GReen Spaces/Safer Places: A Forum on Planning Safer Parks for Women 1-4 (1990) (providing guidelines to safer parks); Robert Campbell, NYC Parks Expert Offers a Proven Growth Plan, BOSTON GLOBE, Oct. 12, 2000, at D5 (outlining Bryant Park manager Dan Biederman's ten rules for building safe parks).

219. Interview with DeMaurice Smith, Special Counsel, U.S. Attorney's Office for the District of Columbia, in Washington, D.C. (Mar. 12, 2000).

220. J. WILLIAM THOMPSON, THE REBIRTH OF NEW YORK CITY'S BRYANT PARK 8 (1997).

221. Design: Bryant Park, 12 PLACES 10, 11 (1998).

222. ANITA R. NAGER \& W.R. WENTWORTH, BRYANT PARK 87 (1976); THOMPSON, supra note 220 , at 8 . 
annual robbery rate dropped from approximately 170 to less than ten). ${ }^{223}$ "[Twenty-five] years ago ... Bryant Park was a nightmare, almost empty except for the drug dealers who stood along the paths.... If Bryant Park was fixable, surely no park is hopeless. And today Bryant Park is a gem, full of life, music, flowers, food, and most important, people." 224

Parks and streets are two examples of public-lands strategies, and we have already considered how government buildings, such as schools and offices, can be constructed to control crime. Decisions about the flow and speed of traffic also have important ramifications for private land use and are integral to understanding crime rates. These examples demonstrate the variety of possible techniques and underscore how crime is influenced by the choices of public officials. ${ }^{225}$

\section{Procurement}

Government cannot change by fiat many private uses of land without resort to nuisance and forfeiture law. But it can expand crime prevention to the private sector through tax breaks and procurement strategies. For example, local governments can provide financial incentives to neighborhoods and property owners to use architectural precautions. One recent example of such incentives is Florida's Safe Neighborhoods Program. The Program was instituted out of a recognition that many of the causes of crime could be eliminated through better design and provides for direct spending on architectural solutions to crime: Property owners' associations, community redevelopment organizations, and local governments can receive $\$ 20,000, \$ 50,000$, and $\$ 100,000$, respectively. ${ }^{226}$ In return, each recipient is required to collect and provide certain information about natural surveillance. ${ }^{227} \mathrm{~A}$ similar regime could be enacted

223. Design: Bryant Park, supra note 221, at 12.

224. Campbell, supra note 218 . Property values in the surrounding areas have increased; real estate brokers now say that the park is no longer a deterrent to customers, but rather " a marketing tool." GARVIN ET AL., supra note 100, at 54; see also id. at 52 ("Now people are thrilled to be there .... They feel safe there and when they feel safe, thousands of them come in. It's harder to commit a crime because criminals feel conspicuous. Even though we have our own security force, which is unarmed, a lot of our security is what I would call "self-enforcing." (quoting Bryant Park manager Dan Biederman)). Similar success stories can be found in Waterfront Park's Story Garden in Seattle, see Lec Fleming, Personal Journey, 84 LANDSCAPE ARCHITECTURE 19 (1994), and Koshland Park in San Francisco, see Hans H. Chen, Making Parks Safe for the Public (June 8, 2000), at http://www.apb.com/safetycenter/family/2000/06/08/parksafety_01.html.

225. ALEXANDER GARVIN, THE AMERICAN CITY 232 (1996) ("An obvious way for government to foster private investment in an area is by making visible, public improvements.").

226. FlA. STAT. ANN. ch. 163.517(1)(a)-(d) (Harrison 2000).

227. Among other things, data must be collected on the "types, frequency, severity, and location" of crime in the district, and that data must be compared to rates from other cities and counties. The district must also provide an analysis of the "land use and environmental and physical conditions of the district, giving particular attention to factors which support or create opportunities for crime, [and] which impede natural surveillance." Id. ch. 163.513(2). 
as a tax expenditure. Generally, governments can use the tax system to provide "carrots" to bring about better architectural precautions. Viewed this way, the home-interest mortgage deduction might have indirect crimeprevention benefits by increasing territoriality and the incentive to care for neighborhoods. ${ }^{228}$

One alternative to such financing arrangements is the use of loan-based strategies. The government currently underwrites a large number of housing loans through Fannie Mae and Freddie Mac. These institutions could require loans to be accompanied by an inspection finding adequate crime prevention mechanisms. Such a law may help create a class of professionals who think about the intersection between architecture and crime. ${ }^{229}$

Another method to influence private architecture is government financing for nonbinding crime-prevention standards. Governments have a wealth of information about where crime occurs and which types of places contribute to crime. Solitary architects, developers, and clients do not always have the resources to determine what types of design work best to prevent crime. Accordingly, governments could direct some resources away from chasing perpetrators down after they commit crimes and toward developing a set of architectural standards. European states such as France, the Netherlands, and the United Kingdom have been using national standards for years. The United Kingdom has a set of national guidelines for design that local officials are under a statutory duty to consider, and the British police have trained specialists called "Architectural Liaison Officers" (ALOs) and "Crime Prevention Design Advisors" (CPDAs). ${ }^{230}$ The entire European Union is now developing a set of central standards, called TC325, that will "provide performance requirements for the prevention of crime" such as "building layout, application of construction elements, roads and paths, and crime preventive lighting." 231 Some

228. Tax breaks and cash subsidies are examples of what Robert Ellickson and Vicki Been have dubbed "beneficence law." ELLICKSON \& BEEN, supra note 209, at 636, 643; see also Curtis J. Berger, Controlling Urban Growth via Tax Policy, 2 URB. L. \& POL'Y 295 (1979) (arguing that tax policy can shape urban development); Barry A. Currier, Exploring the Role of Taxation in the Land Use Planning Process, 51 IND. L.J. 27 (1975) (illustrating the possibility that tax changes may influence land use decisions). To the extent that certain precautions do not generate substantial rewards to the user until a critical mass of neighbors is using them as well, the tax code could provide larger benefits for "first movers" who adopt architectural precautions at early stages. Some forms of tax incentives, such as empowerment zone tax breaks, essentially reward early movers more because the relief is available for a longer period of time. See I.R.C. $\$ \S$ 1391-1397F (1994). Accordingly, tax strategies could be modified to provide for longer tax breaks for those who use architectural protections at earlier stages in time.

229. See GARVIN, supra note 225 , at 5 (observing that, under 1938 Fair Housing Administration mortgage insurance limits, "a house had to conform to published minimum property standards that included structure, materials, and room sizes" and that the effect "was to guarantee a minimum standard of quality on a national scale").

230. Parker, supra note 55, at 4-5.

231. European Committee for Standardization, Market, Environment, and Objectives of CEN/TC325, Prevention of Crime by Urban Planning and Building Design, at 
American police departments, such as New Haven's, are currently putting on their websites information about crime prevention through design. ${ }^{232}$ But these efforts are piecemeal and underfunded, and no architectural crime prevention standards exist. By investing even a small fraction of their massive criminal budgets on architecture, governments can expedite architectural solutions to crime.

The above methods sidestep many of the difficulties with civil regulation of architecture. Public design can be a source of inspiration and guidance to private architects. Nevertheless, if a jurisdiction wants to go further and regulate private land use, there are several plausible regimes.

\section{B. Government as Regulator}

The argument advanced thus far has been primarily concerned with public lands, though mechanisms to regulate private land use deserve attention as well. Although private ordering might generate appropriate architectural solutions to crime, there are four reasons why it may not in some settings. First, some existing government regulations, such as fire codes, prevent effective crime control, thereby precluding the market from adopting these solutions. Second, the vast number of design details, many of which can be subtle or even latent, may require government regulation, just as many health and safety matters are handled today through building codes. This is particularly true for rental units. Indeed, it is worth pointing out that land use is already one of the most heavily regulated aspects of American life, so those jurisdictions that decide to regulate property and structures for crime control will not be extending regulation to pristine areas. Third, when landowners employ architecture to control crime, they may use poor forms of it, for example, barricades that produce negative externalities, such as fear of crime. Greater public attention to architecture can minimize these counterproductive self-help measures. Finally, and perhaps most importantly, the existence of law enforcement itself might skew architectural choices by subsidizing bad architecture. Private residents can afford to pay less attention to design because they are able to rely somewhat on law enforcement; these public expenditures can hamper

http://www.cenorm.be/standardization/tech_bodies/cen_bp/resources/a325.pdf (last visited Nov. $1,2001)$.

232. New Haven Dep't of Police Serv., Crime Prevention Through Environmental Design, at http://www.cityofnewhaven.com/police/html/safety/crimeprev_ed.htm (last visited Oct. 16, 2001); City of San Diego, Tips To Deter Crime Through Design, at http://www.sannet.gov/ police/prevention/deter.shtml (last visited Nov. 1, 2000); Eugene Police Dep't, Keeping Our Community Safe: Crimc Prevention Through Environmental Design, at http://www.ci.eugene.or.us/DPS/police/Crime\%20Prevention/cpted.htm (last visited Oct. 19, 2001); Mesa, Ariz., Police Dep't, Crime Prevention Through Environmental Design, at http://www.ci.mesa.az.us/police/cpted.htm (last visited Oct. 16, 2001). 
optimal ordering. By emphasizing architecture, government may promote a more efficient solution to crime-one that reduces total expenditures on crime by weaning residents off abundant law enforcement.

Government can regulate the construction, placement, and ownership of private buildings and open spaces to bring about crime prevention. Many of these methods of regulation are based on land-use law and employ devices such as impact statements, building codes, exactions, and zoning. Others are based on tort and contract law.

\section{Crime Impact Statements}

Under both federal and state law, agencies must file an "Environmental Impact Statement" (EIS) that details the effect of particular development decisions on the environment. ${ }^{233}$ Rules could similarly require developers to file a "Crime Impact Statement" (CIS) before constructing a large project. The details of who would be required to file the statement, and the amount of review the statement would receive, may vary from one jurisdiction to another. By integrating a CIS into existing local government approval procedures, crime assessments could take place without some of the harms associated with their environmental counterpart. Precisely because local agencies already have so many tools available to them to stop development, the addition of one more might yield greater benefits than harms. ${ }^{234}$

A CIS strategy might accomplish two goals. First, it could generate awareness on the part of clients and developers about ways in which design can control crime. Second, a CIS system could engender a new focus in architecture that could eventually culminate in widespread crime prevention

233. 42 U.S.C. $\$ 4332$ (1994) (requiring agencies to file such statements for major federal actions); see also D.C. CODE ANN. \& 6-981 (1998) (requiring EISs for private development projects); N.C. GEN. STAT. \& 113A-8 (1998) (permitting local government to require developers of major projects to submit EISs); CAL. PUB. RES. CODE $\$ 21160$ (West 2001) (providing that the EIS requirement applies to any private project that requires a lease, permit, or license from a public agency and that the "public agency may require that person to submit data and information ... or to prepare an environmental impact report"). But see CAL. PUB. RES. CODE $\$ 21080.7$ (West 2001) (providing limited exemptions for housing projects). Other statutes require impact statements as well. See, e.g., 2 U.S.C. $\$ 1552$ (1994) (requiring impact statements regarding the Unfunded Mandates Act); 18 U.S.C. $\$ 4047$ (1994) (requiring prison impact statements whenever the executive or the judicial branch submits legislation that could increase or decrease the number of persons incarcerated in federal institutions); 42 U.S.C. $₹$ 1302(b) (requiring the Department of Health and Human Services to provide impact statements when a regulation might impact upon "small rural hospitals").

234. There are typically costs associated with the EIS. See, e.g., Stewart E. Sterk, Environmental Review in the Land Use Process, 13 CARDOzo L. REV. 2041, 2055 (1992) (describing how EISs may slow development); $c f$. Stryker's Bay Neighborhood Council, Inc. v. Karlen, 444 U.S. 223, 227 (1980) (stating that the EISs do not require agencies to "elevate environmental considerations over other appropriate considerations"). Because developers are already required to file an EIS, the CIS will not be as costly. A delay will already occur due to the EIS, and some sets of data for the CIS and EIS may overlap (such as traffic projections from a development). 
through design. Just as the environmental statements led designers to think about the impact of construction on ecosystems, a CIS could induce a cadre of professional architects to contemplate how design and crime interact. ${ }^{235}$ Architects who prepare CISs could take those lessons and apply them in projects of their own, and the statements themselves could be used by architecture schools and professionals to learn about the impact of design on crime.

Moreover, a CIS can force consideration of the positive externalities (such as natural surveillance) and negative ones (such as displacement) of proposed developments. Rules can require developers to analyze not only their own buildings, but also the impact of their projects on surrounding spaces. If developers are too self-interested, or crime predictions too difficult to make, a jurisdiction could have neighborhood commissions retroactively file a CIS after a project is built and operational. Whichever way the CIS is adopted, it will have the advantage of considering externalities, an advantage not available to most other methods of government regulation. A CIS is also flexible enough to accommodate different methods of design, as it focuses on process rather than on substance. ${ }^{236}$ Some architectural methods, however, may prove to be important enough to regulate directly through devices such as housing codes.

\section{Housing Codes}

Building and housing regulation has been used by societies as divergent as the Babylonian empire of Hammurabi (1750 B.C.) and seventeenthcentury England. Today's codes represent one of the most extensive forms of American regulation, though they largely escape the attention of academics. They regulate everything from the size of a balcony to the distance between stairs. As with many other forms of law, a model building code exists, and there are local variations. The West uses the Uniform Building Code, the Midwest has the Building Officials Code Administrators, and the South applies the Southern Standard Building Code. ${ }^{237}$ In large part, the codes have been drafted to ensure fire safety and

235. See LANG, supra note 70 , at 71 (stating that environmental impact assessments "ha[ve] had an effect on the design of many large-scale facilities. ... If nothing else, the law has enhanced planners' and designers' awareness that what they do has an impact on the environment"). Because many EISs are prepared by contractors, and because some private developers are required to file them, a professional class has developed around the EIS, so much so that they even have their own professional association-the National Association for Environmental Professionals. See 40 C.F.R. $\$ 1506.5$ (c) (2000) (permitting contractors to prepare EISs).

236. This feature may also yield public participation benefits.

237. See generally SCOTT, supra note 8, at 1-33 (describing the codes). A note about nomenclature: "Building codes" refer to codes that govern prospective construction; "housing codes" refer to those that govern existing structures. 
the health of occupants and visitors, not to prevent crime. But they can also reflect the power of architecture as an expressive tool, ${ }^{238}$ and these codes may be altered to stress the crime prevention techniques outlined in Part I.

Two main types of building codes exist: those that govern performance and those that regulate design. Performance codes do not specify a particular type of system; instead, they state a requirement that builders can meet through methods of their own choice. For example, a performance code may require that outside walls support a load of one ton, but leave the choice of materials and method of construction open. A design code, in contrast, specifies a type of mechanism or product to be used, such as a fifteen-pin entryway key. Performance codes have more flexibility and permit more evolution in products, but design codes can prevent uncertainty. Crime prevention codes can be written in either fashion. For example, a design regulation could require an outside front door to be metal-plated; alternatively, a performance code could mandate that an average person should not be able to break down the door within a thirtyminute period.

A few regions use design codes to prevent crime. ${ }^{239}$ One advantage of using building codes is that they can reach early stages of human behavior, before expectations are, quite literally, settled when a building is completed ${ }^{240}$ Government officers could work with architects and suggest helpful strategies to avoid extensive retrofitting later. For existing buildings, the expense of retrofitting will require housing codes to use grandfathering provisions strategically in order to avoid imposing large costs on existing property owners for relatively little crime prevention. ${ }^{241}$

238. E.g., BYARD, supra note 96 , at 11 (stating that because architecture is inevitably entangled with expression, government regulation "protect[s] particularly valuable understandings about the human condition expressed by existing architecture and ... ensure[s] continued public access to them").

239. See CROWE, supra note 18 , at 216 ("There are literally thousands of examples of the successful use of local codes and ordinances by CPTED teams to clean up problem neighborhoods and businesses."); BARRY D. YATT, CRACKING THE CODES 117-18 (1998) (describing code provisions designed to block entry). The zoning ordinances for Tempe, Arizona, set forth maximum height requirements for walls and fences in residential areas, and provide that "[a]ll exterior fixtures should be illuminated from dusk until dawn, unless otherwise designated." TEMPE, AZ., GENERAL GUIDELINES CPTED \& 2(a), (d) (1999).

240. See SCOTT, supra note 8, at 49-50 (describing inspection procedures). Some localities use building codes to review crime prevention plans before approving construction, but this is not a widespread phenomenon. CrowE, supra note 18, at 59; Randy Atlas, Crime Prevention Through Building Codes, 9 J. SECURITY ADMIN. 3 (1986). Tempe's planning process requires a CPTED coordinator, who is a police officer, "to sign off on all plans before a building permit or certificate of occupancy is issued," leading one national developer who built a large mall there to exclaim that they had "never before ... consulted with a police department before beginning a project." NAT"L CRIME PREVENTION COUNCIL, DESIGNING SAFER COMMUNITIES: A CRIME PREVENTION THROUGH ENVIRONMENTAL DESIGN HANDBOOK 51 (2000).

241. When building-code strategies are too costly to implement, they could be tempered through the adoption of "smart codes" that strategically relax requirements. HUD recently sponsored the development and publication of a model smart code, the Nationally Applicable 
A building code regime is costly insofar as it may be somewhat inflexible, may overprotect certain areas, and may force government to incur additional expenditures. Because government officers already survey a facility to check for health and safety code violations, the expense of adding a category for crime prevention code violations to the survey would probably not be dramatic. Governments will nonetheless incur costs in developing codes that appropriately balance security against other goals. Some of these costs can be reduced by borrowing knowledge and rules from other comparable jurisdictions. Moreover, building codes typically are developed with the input of the local community, and, in particular, with the input of builders and designers who participate in formal proceedings through "notice and comment" procedures and informally provide advice to building code committees. ${ }^{242}$ Nevertheless, all of these costs can be powerful reasons not to regulate through building codes.

Should governments employ building codes for some of the less burdensome requirements, they will need to adopt sanctions for noncompliance. Compliance with traditional building codes is currently enforced in two ways: by preventing people from entering and occupying (analogous to an injunction) and by fining owners for noncompliance (analogous to money damages). The analogies that $I$ have drawn suggest that a third option of enforcement (and one not used in housing codes), declaratory relief, might prove beneficial—or even adequate by itself-for crime prevention. The failure to conform to some of a code's more expensive and extensive provisions could trigger a declaration by the government that such premises do not meet local crime prevention

Recommended Rehabilitation Provisions, and states are beginning to experiment with such codes. See Roger K. Lewis, Rejuvenating Historic Urban Centers with "Smart" Building Codes, WASH. PosT, May 6, 2000, at G13; Angela Paik, Change Proposed in Building Rules; "Smart Code" Would Encourage Redevelopment, Rehabilitation, WASH. POST, Jan. 26, 2000, at B8 ("Supporters say Smart Codes would make revitalization easier and in tum help cities and towns rid themselves of run-down or vacant buildings." ). In 1997, New Jersey was the first state to create and implement a set of these codes, leading to a forty percent increase in spending on rchabilitation of existing buildings the next year. See Peter $\mathbf{H}$. Brink, New Frontiers in Community Preservation, Address at the Maine Preservation Annual Conference (May 11, 2001), at http://www.mainepreservation.com/brink_speech.htm.

Pattern guidelines, which establish looser city-design requirements, could also be used. For example, San Francisco uses such guidelines to regulate building size, transportation, and open space. These guidelines are in place in order to ensure that new developments will fit into "established city and neighborhood patterns in a complementary fashion. Harmony with existing development requires careful consideration of the character of the surroundings at each construction site." JON LANG, URBAN DESIGN 85-86 (1994).

242. SCOTT, supra note 8 , at 26 (describing typical notice and comment procedures). Although the specifications will differ, many of the same features that would be regulated by a crime prevention code are currently regulated by building codes. YATT, supra note 239, at 249-53 (discussing building code regulation of doors and locks). Empirically, it is not clear that building codes increase the cost of construction. See Richard F. Muth \& Elliot Wetzler, The Effect of Constraints on House Costs, $3 \mathrm{~J}$. URB. ECON. 57 (1976) (reporting a regression analysis study finding that following model codes does not result in cost incrcases). 
requirements. No fine would be imposed, but the declaration would notify prospective customers, tenants, guests, and buyers that the premises are not up to par. The threat of such declarations would create an ex ante inducement for architects to build safety considerations into their plans, and also for owners to retrofit if doing so is necessary to attract tenants or raise rents. A market for information-in this case, information about safe and unsafe conditions-will not always develop without government regulation. In order to save money, architects and builders often cut corners, particularly in ways that are latent or not immediately apparent. Such costcutting is not always discernible by purchasers, even though it might keenly interest them if they knew about it. ${ }^{243}$

The traditional remedies of fines and injunctions are also potential vehicles for encouraging compliance with crime prevention standards. There are, of course, costs to such systems, such as the aforementioned expense of enforcement, the harm imposed on owners in waiting for approval, and the risk of overdeterrence and investment in excessive precautions. But fines and injunctions will work well for some important architectural precautions. Housing developers, homeowners, and commercial establishments are far more responsive to the threat of sanctions than are criminals. Governments can play on this asymmetry by placing comparatively less liability on these (more responsive) actors, instead of more liability on (less responsive) criminals, to achieve the same result. ${ }^{244}$ Studies have shown that jurisdictions that adopted crime prevention codes had a drop in their crime rates: Burglary dropped by onehalf in one area, by over one-fifth in another, and by one-tenth in a third area. ${ }^{245}$

Indeed, the use of building codes to prevent crime has a strong historical precedent going back to 1285 . Edward I enacted the Statute of Winchester, a code designed to prevent the concealment of robbers. ${ }^{246}$ The

243. This is a standard rationale for the use of building codes. See STEPHEN R. SEIDEL, HOUSING COSTS AND GOVERNMENT REGULATIONS 73-74 (1978) ("The complexity of today's construction methods renders it unlikely that the prospective home buyer will have sufficient technical knowledge to make an informed decision about the structural integrity of the unit. Building codes serve as a substitute for... complete knowledge on the part of the consumer...."). In addition, the lack of govemment regulation of architecture may produce negative externalities as residents use barricades that produce fear. See supra text accompanying notes $171-172$.

244. See Katyal, supra note 3, at 1011 (discussing how teenage hackers might be particularly responsive to cost deterrence); $i d$. at 1095,1102 (observing that government should play on the fact that Internet Service Providers and computer programmers are more responsive to legal sanctions than are criminals).

245. Atlas, supra note 240 , at 4 . Some evidence shows that installing architecture to prevent burglary during new construction adds $\$ 200$ to $\$ 300$ to the construction cost, and retrofitting a house with similar protection costs between $\$ 350$ and $\$ 600$. Id.

246. Statute of Winchester, 1285, 13 Edw. 1, ch. 1. Jenks wrote that the Statute's "purpose is clear as the day. It insists ... that the good citizen is not merely to abstain from disorder and crime, sitting by with folded hands whilst others defy the law, but that he is bound to assist the 
Statute was enacted during the time of Robin Hood, when apprehension and conviction of thieves were rare. ${ }^{247}$ One provision of the Statute imposed liability for certain robberies on members of the town who failed to catch an offender; another provision directly regulated environmental design to reduce crime. ${ }^{248}$ Under the latter provision, highways had to be enlarged and bushes had to be cleared for 200 feet on either side of the highway. The Statute went so far as to shift blame to property owners, ordering that if any robberies or other felonies should occur "by Default of the Lord that will not abate the Dyke, Underwood, or Bushes . . . the Lord shall be answerable for the Felony." 249 In so doing, the Statute built on earlier English precedents that governed design. ${ }^{250}$

The design regulations in the Statute of Winchester were "unambiguously welcomed, judging by the number of presentments that resulted." 251 Charges were brought against many property owners, including the King, the Queen, and the Abbot of Westminster. ${ }^{252}$ The Statute of Winchester demonstrates some of the possible approaches law

forces of order and good govemment." EDWARD JENKS, EDWARD PLANTAGENET (EDWARD I): THE ENGLISH JUSTINIAN 220 (1923).

247. Henry Summerson, The Enforcement of the Statute of Winchester, 1285-1327, $13 \mathrm{~J}$. LEGAL HIST. 232, 233, 235 (1992). Lord Coke writes that "[t]his Robert Hood lived . . . in woods and deserts, by robbery, burning of houses, felony, waste and spoile" and "[a]gainst these [robbers] was the Statute of Winchester made in $13 \mathrm{E}$. 1. for preventing of robbery, murders, burning of houses, ... and remedy provided by that act for the arresting of [these robbers]." COKE, supra note 58, at 197.

248. Statute of Winchester ch. 2 (imposing an affirmative duty on some individuals); id. ch. 5 (directing " [ $t]$ hat Highways leading from one Market Town to another shall be enlarged, whereas Bushes[,] Woods[,] or Dykes be, so that there be neither Dyke[,] Tree[,] nor Bush, whereby a Man may lurk to do hurt, within two hundred foot [on either side]"). The Statute also required a park to be set "the space of two hundred foot from the Highways ... or that he [the Lord who built it] make such a Wall, Dyke, or Hedge, that Offenders may not pass, ne return to do evil." Id.

249. Id. ch. 5. If an owner of such trees and bushes could not remove them himself, the county would be required to "aid him therein." Id.

250. As Summerson reports,

As early as 1227 the bailiff of the Prior of Holy Trinity, Canterbury, was ordered to have his lord's wood cut back for half a furlong on either side of a road in Essex, "for the maintenance of the peace." In 1261 the justices itinerant in Oxfordshire ordered that the mound which gave its name to Cutslow be levelled to the ground because criminals were in the habit of lurking in the hollow on the top of the mound, while in 1279 an inquest found that "it would be expedient for the keeping of the King's peace and the security of passers-by" for the Abbot of Lilleshall to bring under cultivation 30 acres of heavily wooded ground alongside Watling Street in Shropshire.

Summerson, supra note 247, at 233 (footnotes omitted).

251. Id. at 242. The Statute was well-publicized early on, as Dunstable Priory cut back its woods in Bedfordshire in 1286, and in 1287, jurors in Wiltshire "twice presented defects on the part of the Abbot of Stanley, both involving the making of ditches, in which criminals could lurk, too close to roads." Id. at 237.

252. Id. at 242-43. Even thirty years later, during Edward II's reign, "jurors who otherwise had little to say except that the articles of the Statute were kept either well or badly ... would still report on woods endangering the safety of the roads. Their persistence on this subject indicates that this was a clause which met a genuine need." Id. at 243. Stephen wrote, however, that the entire Statute later fell into disuse. 1 James FitzJames STEPHEN, A History OF THE CRIMINAL LAW OF ENGLAND 189 n.2 (London, Macmillan 1883). 
can use, from regulating public and private structures (through devices such as building codes) to regulating the behavior of bystanders (through reporting or intervention requirements).

Yet some building and fire codes today, for no good reason, are written to preclude the use of architectural techniques that prevent crime. In a sense, then, safety and fire prevention codes may be resulting in some increase in the crime rate. In the context of parking facilities, Mary Smith has found that building codes can "hinder effective use of CPTED principles" and specifically isolates rules requiring height limits on lighting poles (which decrease uniform illumination), landscaping around parking facilities, and removal of exit stairs from public view. ${ }^{253}$ Codes that require enclosed stairs are of special concern: "Due to fire code requirements, the stairs are virtually sealed off. ... This arrangement effectively precludes the possibility of visual or auditory monitoring of activity in the stairwells. ... Not surprisingly, fire stairs are the area in which a high percentage of the rapes occur, and in which narcotics addicts congregate." 254 Architecture and technology can be deployed, however, in ways that both prevent fire and minimize crime. ${ }^{255}$

Police should also have concurrent jurisdiction with other local agencies over code enforcement. Police used to pursue such tasks but now generally believe that these violations are not their responsibility. ${ }^{256}$ While housing inspectors should by no means be replaced, police involvement would underscore the relationship between the housing code and crime.

Finally, government can also regulate architectural features through the strategic use of exactions. Exactions permit local governments to condition permission for development on the owner's grant of certain property rights to the government. While constitutional restrictions on exactions exist, exactions may prevent crime when properly used. ${ }^{257}$ Local governments can

253. SMITH, supra note 28; see also NEWMAN, supra note 26 , at $118-19$ (explaining that some crime prevention strategies have been blocked as violations of the building code); Gerald F. Pyle, Spatial and Temporal Aspects of Crime in Cleveland, Ohio, 20 AM. BEHAV. SCI. 175, 194 (1976) (same).

254. NEWMAN, supra note 26 , at 89 . Similarly, some codes require fire escapes in apartment buildings to be constructed in a scissors fashion, with crisscrossing ladders that permit individuals to get off at a lower floor and to pick one of two sides of a building to exit. Due to the

many different possible exits, ... it would take a contingent of policemen to apprehend a criminal, even if they knew for sure that he was within a particular building. More important than apprehension, however, is the fact that a criminal casing a scene will perceive at a glance the number of escape options open to him and realize his risks are minimal.

Id. at 34-35.

255. For example, cameras could be used to monitor stairways. At least some of the problems with public cameras are not applicable to this solution, for cameras would not inhibit social activity in these isolated areas.

256. SKOGAN, supra note 22 , at 1-2.

257. In particular, there must be an "essential nexus" between what the developer will provide and the public harm that the development would likely create. Nollan v. Cal. Coastal 
demand that developers set aside a portion of land for uses that promote natural surveillance (for example, well-designed parks and other land uses that bring people out of doors), devote land to security measures (such as egress and ingress control), and use adequate lighting. ${ }^{258}$ Exaction strategies are particularly appropriate when a local government wants to make caseby-case decisions instead of adopting broad regulations through building codes. However, wide discretion can result in weaker architectural regimes and accusations of preferential treatment.

\section{Zoning}

The mention of preferential treatment brings to mind another form of land-use regulation-zoning. The placement of residences, businesses, parks, and other land uses can be used evenhandedly to prevent crime. Cities that have adjusted their zoning practices have lowered their crime rates. ${ }^{259}$ Unfortunately, many current zoning practices disregard or even work against crime prevention goals.

Cities can zone for crime prevention in four general ways. First, instead of creating districts of single uses - the houses go on the west side and the businesses on the east-zoning can strive for diversity of use. Diversity encourages people to avoid their cars and engage their local community. It brings people together at different times of the day and night so that private deterrence flourishes. ${ }^{260}$ Architects have emphasized for some time how

Comm'n, 483 U.S. 825, 837 (1987). The dedication of property must also be "reasonably related" or "roughly proportional" to the impact of the proposed development. Dolan v. City of Tigard, 512 U.S. 374, 391 (1994). Some cities, including San Francisco and Boston, have even levied exactions on developers for child care. See ELLICKSON \& BEEN, supra note 209, at 806.

258. See Jesse DuKeMINIER \& JAMES E. KRIER, PROPERTY 1010 (4th ed. 1998) (discussing how subdivision regulation ordinances can require a developer to provide for lighting, sidewalks, and other facilities). Current subdivision regulations can be quite intrusive, governing matters such as the maximum length of blocks, minimum grade of streets, prevalence of right-angle intersections, and minimum street widths. See ELLICKSON \& BEEN, supra note 209, at 484.

259. TAYLOR \& HARRELL, supra note 31.

260. JACOBS, supra note 30, at 14; Hok-Lin Leung, How Crowded Is Overcrowded? (1993), at http:/www.ismcpi.org/ica/reference/overcrowded.htm. Robert Ellickson has detailed a quite different zoning proposal, arguing that panhandling and bench squatting should be considered a chronic street nuisance in certain instances. Robert C. Ellickson, Controlling Chronic Misconduct in City Spaces: Of Panhandlers, Skid Rows, and Public-Space Zoning, 105 YALE L.J. 1165 (1996). Ellickson recognized that offensive street behavior could deter people from using public spaces and that some forms of minor disorder could spiral into more serious crime. Id. at 1171, 1176-77. To the extent these practices are zoned out of cities, constitutional problems may emerge, particularly in light of increasing scrutiny of commercial speech restrictions. See Stephen R. Munzer, Ellickson on "Chronic Misconduct" in Urban Spaces: Of Panhandlers, Bench Squatters, and Day Laborers, 32 HARV. C.R.-C.L. L. REV. 1, $38-45$ (1997). In any event, architectural solutions that emphasize access controls and greater natural visibility are a less restrictive alternative, and can be implemented (like Ellickson's proposals) with a preference for bottom-up solutions that permit spatial variance. There may be some synergy between Ellickson's approach and design-based solutions, in that removing panhandlers and other individuals might 
diversity can attract energy to a neighborhood and contribute to a sense of pride. $^{261}$ Such views have culminated in one of the most exciting architectural movements in several decades, New Urbanism. Principally associated with Andres Duany, Elizabeth Plater-Zyberk, and Peter Calthorpe, the movement strives to facilitate community through design. ${ }^{262}$ While these writers have not focused on crime, the discussion in Part I suggests that New Urbanism may have important implications for crime prevention. For example, restrictions on the maximum setbacks of houses and requirements for their minimum setbacks can decrease crime-the former by encouraging natural surveillance as residents are placed near streets, the latter by providing land for sidewalks, which in turn promotes natural surveillance and builds communities. Again, these strategies carry costs and cannot be implemented until those costs have been weighed against crime reduction and other benefits.

Second, land uses that are known to decrease crime, such as religious buildings, should be strategically placed. As Tracey Meares and Phil Heymann have shown, churches lower crime rates by cultivating social organization and a sense of order. ${ }^{263}$ An architectural perspective suggests that planners can incorporate these insights by encouraging houses of worship to be centrally located. By making churchgoing part of the daily fabric of life, instead of something requiring a special trip, social organization will expand. Putting houses of worship in central locations also creates natural surveillance in the area. Such placement may also have a geographic halo effect. Due to this halo effect, certain buildings, such as churches, may reduce the crime rate because they create feelings of guilt or shame in potential perpetrators and because the absence of crime against such structures furthers visible social order. By contrast, other buildings, such as abandoned houses, may increase the crime rate because they convey the impression that crime is normal.

increase the amount of natural surveillance by others. On the other hand, panhandlers can be helpful sources of information to the police, as they too engage in surveillance.

261. E.g., Anthony Lord, Comfort in the City, in PERCEPTION AND ENvIRONMENT: FOUNDATIONS OF URBAN DESIGN 67, 67-70 (Robert E. Stipe ed., 1966).

262. PETER CalthorPe, THE NEXT AMERICAN METROPOLIS (1993); ANDRES DuANY \& ELIZABETH PLATER-ZYBERK, TOWNS AND TOWN-MAKING PRINCIPLES (Alex Krieger \& William Lennertz eds., 1991); THE NEW URBANISM, supra note 78; Andres Duany et al., New Town Ordinances and Codes, 59 ARCHITECTURAL DESIGN 71 (1989); see also MICHAEL J. SANDEL, DEMOCRACY'S DISCONTENT 335-36 (1996) (praising New Urbanism for building communities).

In addition to zoning, the New Urbanists strategically use building codes. See Scully, supra note 78 , at 226 (describing how Duany and Plater-Zyberk's conception is different from that of their predecessors "in one fundamental respect: They write a code that controls the buildings as well as the plan. They therefore ensure that the three-dimensional reality of the town will fulfill the concept adumbrated in its plan-without themselves having to design every building in it"); id. at 227 (noting that "the important place-maker is the code")

263. Philip B. Heymann, The New Policing, 28 FordHAM URB. L.J. 407, 412, 426 (2000); Meares, supra note 21 , at $413-15$. This is particularly the case for African-American churches, which are often the only autonomously controlled social institutions in inner cities. 
Third, zoning decisions must be periodically reassessed in light of changing economic and social conditions. When an area appears to be on the verge of a crime increase, cities could "coordinate housing, zoning, and sanitation personnel in an effort to prevent or slow increases in physical deterioration and housing abandonment. Such efforts might block the emergence of higher crime rates, higher fear levels, or declining commitment to the community." 264

Fourth, zoning decisions could aim explicitly to encourage residents to stay in a geographic area for long periods of time. A key factor in preserving the quality of neighborhoods and preventing slums is to encourage rootedness in the community. ${ }^{265}$ This goal does not require people to occupy the same housing unit all of their lives; that would unfairly penalize families with children, those with incomes that vary, and others. Instead, if a neighborhood has enough diversity in its housing stock, with units spanning a range in price, this diversity may encourage residents to stay in their familiar neighborhoods. To the extent that a city zones out nonconforming houses, however, the ability of residents to stay is undermined. As populations turn over, crime may flourish because social institutions are unlikely to form when people believe they are short-term residents. ${ }^{266}$ In addition, social networks fail to emerge when individuals do not know each other well due to high residential turnover. ${ }^{267}$ Group identity and altruistic behavior are far less likely to emerge in these circumstances. Again, such zoning changes may not be justified in places where crime rates are low or costs of nonconformity are high, but, in some circumstances, these changes may facilitate better crime prevention.

If keeping residents in a neighborhood over a sustained period of time reduces the crime rate, this may also become a somewhat weighty argument to favor rent control in areas at high risk for crime. ${ }^{268}$ Forms of rent control that prevent landlords from raising the rents of existing tenants above a certain percentage essentially force people to stay in their existing location. ${ }^{269}$ Most argue that this feature of rent control is a vice, and those

264. TAYLOR \& HARRELL, supra note 31 , at 20.

265. JACOBS, supra note 30, at 139-40, 271.

266. BURSIK \& GRASMICK, supra note 81, at 33; Taylor \& Gottfredson, supra note 111, at 390.

267. BURSIK \& GRASMICK, supra note 81, at 33 .

268. While I concentrate on rent control, a similar argument might be made for real estate transfer taxes, which decrease the mobility of owners and encourage rootedness in a community.

269. Rent control creates incentives for tenants to remain in their units longer than they otherwise would because tenants enjoy the continued benefits of paying below-market rents. This is particularly true in jurisdictions that feature vacancy decontrol, which allows a landlord to reset the rents at any level once the current tenant leaves. Because rent control prevents the market from clearing, there is a shortage of units in rent-controlled jurisdictions, motivating current tenants to remain in their units. Empirical findings strongly support the conclusion that rent control lengthens occupancy periods. ANTHONY DOWNS, RESIDENTIAL RENT CONTROLS 21-22 (1988). 
who disagree, such as Professor Radin, have argued that such stability fosters neighborhood identity. ${ }^{270}$ However, proponents of rent control have not explained fully why such an identity is important. ${ }^{271}$

A perspective focused on architecture and crime suggests one answer. Rent control's encouragement of rootedness and territoriality may facilitate better natural surveillance and, ultimately, crime prevention. An exhaustive study of the literature has revealed no one who has yet drawn the connection, but the relationship appears to be tenable. When neighbors are strangers to each other due to rapid turnover, it is difficult to exercise surveillance. High turnover rates can also decrease the effectiveness of community organizations and increase the crime rate. ${ }^{272}$ Additionally, rent control might decrease crime by creating incentives for renters to take care of neighborhoods, as they will become invested in an area in which they know they will reside for some time. ${ }^{273}$

On the other hand, there are some reasons why rent control could have negative effects on architecture, and thereby increase the crime rate. Rent control may lead to dilapidated buildings and the creation of slums, which might increase fear and lead to less natural surveillance and ultimately more crime. ${ }^{274}$ In addition, rent control might reduce the incentive for a landlord

There may be some mobility through side contracts between tenants, but such contracts are often illegal and not easy to fashion.

270. Margaret Jane Radin, Residential Rent Control, 15 PHIL. \& PuB. AFF. 350, 368-69 (1986).

271. See Jeffery James Minton, Rent Control: Can and Should It Be Used To Combat Gentrification?, 23 OHIO N.U. L. REV. 823, 851 (1997) (stating that to "make the argument for rent control rest on more solid footing, more empirical evidence is necessary documenting the value of community in residents' lives to prove that its preservation is favored to unhindered mobility"); see also Robert C. Ellickson, Rent Control: A Comment on Olsen, 67 CHI.-KENT L. REV. 947, 953 (1991) (" [T] he overall desirability of keeping people in their current places is not obvious. Commentators are prone to romanticize life in the peasant village, small town, or urban enclave.").

272. SKOGAN, supra note 22, at 169.

273. Margarita Hill, Comprehensive Community Planning as a Tool for Neighborhood Revitalization and Crime Prevention, Paper Presented at the Third International CPTED Conference, Washington, D.C., 1988, at http://www.ismcpi.org/ica/reference/CPTED-1998 _08.htm (last visited Oct. 19, 2001) (observing that most renters are not likely "to invest in neighborhood improvements and are less likely to report or identify criminal activity"). Rent control might also increase the diversity of incomes in a neighborhood by creating quite disparate rents for similar units. Income diversity on average might reduce crime by generating more natural surveillance, but it might increase crime by fragmenting the community.

274. Some have argued, for example, that the reduced investment return creates disincentives for owners to invest in housing improvements, maintenance, and other security-enhancing measures, leading to declines in housing quality and maintenance, E.g., Richard A. Epstein, Rent Control and the Theory of Efficient Regulation, 54 BROOK. L. REV. 741, $765-67$ (1988). Empirical findings, however, are mixed as to the impact of rent control on housing quality. For instance, one review of the literature found several studies showing definite declines in owner investments in maintenance and repair under more stringent rent control. However, studies of more moderate programs revealed an ambivalent relationship, leading some to conclude that there is no clear correlation. DowNS, supra note 269 , at 20-21. If rent control does lead to poor quality housing stock, it can increase the crime rate. See, e.g., SKOGAN, supra note 22, at 42 (arguing that dilapidated buildings increase crime). Another way in which rent control might increase crime, as 
to incorporate crime prevention into architecture, as the market will not reward such efforts. ${ }^{275}$ These questions about rent control and crime are too difficult to answer here, but the framework advanced in this Article suggests they deserve attention.

\section{Tort Suits}

Another option to bring about architectural protections involves tort suits against architects and owners. These suits have already been brought against landlords and shopping malls on the theory that the failure to observe certain safety precautions was a contributing factor in the commission of a crime. ${ }^{276}$ Tort liability can spur the incorporation of effective design, but it runs the risk of consuming too many resources and becoming overly burdensome.

Lawsuits could be brought against architects on a product-design defect theory, arguing that their design facilitated a crime. Because many jurisdictions have strong statutes of repose on liability for design defects, however, such suits are difficult to bring. ${ }^{277}$ In addition, causality with respect to a given crime may be difficult to prove. For these reasons, regulation of architects is better accomplished through building codes than through tort. The failure to comply with a building code, however, could give rise to negligence per se liability, should the particular provision of the code be something that a jurisdiction intensely wants to encourage.

In contrast to product liability lawsuits against architects, suits against landowners have fared well in the courts—so well that "liability has been one of the greatest motivators for property owners to improve security." 278 The Uniform Residential Landlord Tenant Act requires landlords to provide safe housing conditions, and some states use similar provisions to impose

Robert Ellickson has suggested to me, is that it poisons relations between landlords and tenants, leading to more crime between them, or possibly even to more crime generally as friction and anger take root.

275. Even a free market, however, may not reward landlords who take such precautions, because many of them are not apparent. See supra text accompanying notes 171-172, 243.

276. One study of 267 such cases from 1983 to 1992 found that the average settlement was in excess of $\$ 545,000$ and the average verdict was $\$ 3.35$ million. NORMAN D. BATES \& SUSAN J. DunNell, Liability CONSUltaNTS, Major DEVElopMENTS IN PREMISES SECURITY LiabiLITY 6-7 (1993). A subsequent study of 731 cases from 1993 to 1997 found that the average award was lower than this figure. See NORMAN D. BATES \& JON D. GROUSSMAN, LIABILITY CONSUlTANTS, MAJOR DEVELOPMENTS IN PREMISES SECURITY LIABILITY II, at 6-7 (1999).

277. E.g., Post, supra note 115 , at 18, 25 (explaining the difficulty with the product-design theory).

278. See BATES \& DUNNELL, supra note 276, at 8; see also Daniel B. Kennedy, A Synopsis of Private Security in the United States, 6 SECURITY J. 101, 104 (1995) (stating that "many organizations expend substantial revenues on private security systems" in response to such lawsuits). 
tort liability. ${ }^{279}$ A leading case in favor of liability is Kline v. 1500 Massachusetts Avenue Apartment Corp., in which the D.C. Circuit held that a landlord is "obligated to protect those parts of his premises which are not usually subject to periodic patrol and inspection by the municipal police." ${ }^{280}$ A tenant had been assaulted and robbed, and placing liability on the landlord, the judges reasoned, would create the proper incentives to use better security precautions:

As between tenant and landlord, the landlord is the only one in the position to take the necessary acts of protection required. . . . Not only as between landlord and tenant is the landlord best equipped to guard against the predictable risk of intruders, but even as between landlord and the police power of government, the landlord is in the best position to take the necessary protective measures. Municipal police cannot patrol the entryways and the hallways, the garages and the basements of private multiple unit apartment dwellings. ${ }^{281}$

Many other lawsuits have been successfully brought on the basis of inadequate security - for failures such as inadequate lighting and locks. ${ }^{282}$ Courts have also upheld suits based on structural conditions that invite crime, reasoning that doing so will bring about better design protections. ${ }^{283}$

279. See UNIF. RESIDENTIAL LaNDlORD \& TENANT ACT $\$ 2.104$ (a)(3), 7B U.L.A. 566 (1972); Brock v. Watts Realty Co., 582 So. 2d 438, 441-42 (Ala. 1991) (upholding liability where a landlord failed to maintain locks in satisfactory condition, in violation of the Birmingham Housing Code); Paterson v. Deeb, 472 So. 2d 1210, 1217 (Fla. Dist. Ct. App. 1985) (finding liability because a landlord did not comply with a Florida statute requiring effective locks and finding that the statute had no foreseeability requirement); Braitman v. Overlook Terrace Corp., 346 A.2d 76, 85 (N.J. 1975) (stating that a landlord could be liable for burglary due to the New Jersey Hotel and Multiple Dwelling Law, which requires dead-bolt door locks).

280. 439 F.2d 477, 487 (D.C. Cir. 1970).

281. Id. at 484 .

282. E.g., Frances T. v. Vill. Green Owners Ass'n, 723 P.2d 573 (Cal. 1986) (holding that failure to provide adequatc lighting is actionable for negligence); Isaacs v. Huntington Mem'l Hosp., 695 P.2d 653 (Cal. 1985) (opining that the failure to maintain adequate lighting is relevant to foreseeability); Mullins v. Pine Manor Coll., 449 N.E.2d 331 (Mass. 1983) (upholding a jury award for the plaintiff against a college for a rape committed in a dorm room, despite the lack of prior reports of violent crime on campus); Johnston v. Harris, 198 N.W.2d 409 (Mich. 1972) (upholding liability for failure to provide locks); Trentacost v. Brussel, 412 A.2d 436, 440-41 (N.J. 1980) (holding that mugging is a foreseeable result of the absence of a lock on a front entrance); Braitman, 346 A.2d at 84 (stating that a landlord was liable for "unreasonably enhanc[ing] the risk of loss due to theft by failing to supply adequate locks to safeguard the tenant's premises after suitable notice of the defect"); Small v. McKennan Hosp., 403 N.W.2d 410 (S.D. 1987) (finding that a hospital might be liable for rape and murder, in part because the lighting did not meet industry standards); Tedder v. Raskin, 728 S.W.2d 343, 348 (Tenn. Ct. App. 1987) (stating in dicta that "[s]uch simple measures as providing adequate lighting in hallways and locks on outside entrances are peculiarly within the landlord's capability and could substantially reduce the risk of harm to his tenants. Under these circumstances, to hold the landlord unaccountable for injuries proximately caused by the condition of the common areas would be unconscionable").

283. Cooke v. Allstate Mgmt. Corp., 741 F. Supp. 1205, 1210 (D.S.C. 1990) (finding that the physical layout of a building and, in particular, the positioning of a ladder nearby, can give rise to 
One reason why such lawsuits may generate architectural precautions concerns insurance companies. Insurance companies make substantial profits by exploiting downward cost curves. They insure against a condition that has some likelihood of occurring, and calculate the premium on that chance. They then educate the customer about ways to reduce that likelihood, which benefits the customer in that she learns valuable information, and simultaneously benefits the insurance company by reducing expected payouts. ${ }^{284}$ For example, a large percentage of fire prevention today is the result of insurance companies that took aggressive steps to educate construction companies and owners about fire prevention. ${ }^{285}$ A similar result may be induced by crime-prevention lawsuits. ${ }^{286}$ If so, tort liability will rely on insurers as educators and help bring about better architectural precautions.

As with most tort regimes, liability can lead to the adoption of socially inefficient precautions, because judges and juries will not always accurately calibrate liability and cost. The degree of liability imposed should take into account the fact that victims will often be able to prevent crimes on their own; too much liability borne by property owners can be wasteful. Consider

negligence liability); Stribling y. Chi. Hous. Auth., 340 N.E.2d 47 (Ill. App. Ct. 1975) (finding liability when a landlord failed to seal off a hole adjacent to a tenant's apartment through which previous burglars had entered); COREY L. GORDON \& WILLIAM BRILL, THE EXPANDING ROLE OF CRIME PREVENTION THROUGH ENVIRONMENTAL DESIGN IN PREMISES LIABILITY 4 (Nat'I Inst. of Justice, Research in Brief, Apr. 1996) ("CPTED has been useful in assisting plaintiffs in demonstrating the causation element, i.e., that not only was the defendant's conduct unreasonable but that had the defendant acted reasonably, it would have been a substantial factor in deterring the crime."); Madeline Johnson, Landlord's Responsibility for Crime: Determining Legal Causation, 17 REAL EST. L.J. 234, 238-4l (1989) (discussing how architectural principles can demonstrate the causation of crime); Telephone Interview with Norman D. Bates, President, Liability Consultants (June 28, 2001) (stating that several lawsuits have been brought successfully on the basis of architectural designs against landowners).

284. $C f$. W.A. DinSDALE, ELEMENTS OF INSURANCE 3 (3d ed. 1963) ("[I]nsurers build up considerable knowledge and experience which they place at the disposal of their policyholders by making recommendations with a view to the reduction of loss ...."); HUEBNER, supra note 195 , at 16 " "Property insurers are ideally situated, because of their interest in the matter and their strategic position to acquire the necessary information and apply the needed remedies, to pursue prevention of loss activities."); STEVEN SHAVELL, ECONOMIC ANALYSIS OF ACCIDENT LAW 197 (1987) (making a similar point).

285. HUEBNER, supra note 195, at 376 ("The fire insurance companies ... have performed numerous important services in their efforts to reduce the nation's fire waste. Because they have been peculiarly fitted for the task and at the same time have had an incentive based upon selfinterest, the insurance companies have made vital contributions to the field ...."); F. HARCOURT KITCHIN, THE PRINCIPLES AND FINANCE OF FIRE INSURANCE 175-76 (1904) (stating that, in Britain, "[i]t is hardly too much to say that the fire offices, by giving favourable terms for construction designed expressly to prevent fires, have done more to reduce the fire danger in our cities than the efforts of legislators and municipal administrators during several generations").

286. The only analysis of this point I have found is STUART WINCHESTER \& HILARY JACKSON, RESIDENTIAL BURGLARY (1982), which states: “[I]nsurance companies may . . . be in a better position to adopt a more coercive approach as illustrated by their success in persuading commercial companies to improve security" because "victims ... frequently look to insurance companies for security advice rather than to the police ...." Id. at 11-12. 
Judge Posner's opinion in Wassell $v$. Adams. ${ }^{287}$ A couple from Pennsylvania checked into a motel situated close to a high-crime area in Chicago. When a man knocked on the door in the middle of the night, the woman opened the door, thinking it was her fiancé, and admitted the stranger into the room. She was raped, and the perpetrator was never found. She brought suit against the motel, claiming that the motel had been negligent in failing to take adequate precautions. A jury found that the motel was negligent, and assessed the victim's damages at $\$ 850,000$. But the jury also found that the victim had been ninety-seven percent at fault, and, under the Illinois comparative fault statute, apportioned the damages. The victim, on appeal, claimed that she was not negligent and that, in any case, her negligence was immaterial.

Judge Posner recognized that the motel could easily warn its customers about the high crime rate, and so if the calculation were simply one about who could cheaply issue warnings, the motel was at fault. ${ }^{288}$ But the problem with that reasoning, he found, was that the warnings would not have prevented the crime, as the victim thought that her fiancé was knocking. ${ }^{289}$ Judge Posner also observed, however, that the motel could have employed an inexpensive security guard and noted that had he been reviewing the facts, he would have assessed the motel's liability at more than three percent. ${ }^{290}$ Judge Posner therefore scrutinized the evidentiary record and suggested liability that hewed to the cost and effectiveness of various precautions.

Many judges will not make these calculations, however. One problem with imposing tort liability is that, without adequate legislative guidance, judges and juries may have to decide questions about architectural design and likelihood of crime, and other difficult questions of causation. This is very resource-intensive, particularly when such determinations must be made in every case. Experts will be hired, testimony taken, and lengthy arguments made. The costs of process may dwarf the expected recovery and induce many victims to avoid bringing suit in the first place. ${ }^{291}$ Moreover,

287. 865 F.2d 849 (7th Cir. 1989).

288. Id. at 855 .

289. Id. ("It is unlikely that a warning would have averted the attack. Susan testified that she thought the man who had knocked on the door was her fiancé. Thinking this, she would have opened the door no matter how dangerous she believed the neighborhood to be."). This conclusion is, of course, contestable, as a warning by the motel could have made the victim more likely to scrutinize a knock.

290. Id. at 855-56 " A guard would have cost $\$ 50$ a night. That is almost $\$ 20,000$ a year. This is not an enormous number.... If we were the trier of fact... we would assess the defendants' share at more than 3 percent.").

291. An emphasis on architecture, however, does not mean that tort liability should be enhanced in every instance. For example, some states permit plaintiffs to show that a crime was foreseeable by introducing evidence of crimes in neighboring locations. In Early v. N.L.V. Casino, Corp., 678 P.2d 683 (Nev. 1984), the plaintiff sued a casino for an assault in its restroom. Although there had been no such reported assaults in the casino's restroom, the plaintiff was 
the lawsuits may focus on target-hardening and will not generate attention to the more subtle forms of architectural precaution.

For that reason, if a jurisdiction wants to use tort liability to encourage architectural solutions to crime, it could either create a specialized administrative court where such lawsuits could be brought, or adopt a building code enforced by negligence per se liability. ${ }^{292}$ Either method would avoid having each judge or jury reinvent the wheel to determine what types of precaution are necessary. Negligence per se would also provide guidance to parties and insurance companies well before litigation even became an issue, but a specialized court might be better suited to making locally tailored architectural determinations.

At present, however, the risk of tort suits provides a disincentive to employ security measures and document criminal activity, because such steps can constitute a landowner's admission of knowledge of crime risks. Such precautions can further suggest that landowners have voluntarily assumed the risk of providing security. ${ }^{293}$ Accordingly, governments might develop "safe harbor" provisions that insulate entities that comply with design requirements from tort lawsuits, or they might adopt rules to bar admission of such improvements into evidence.

\section{Contractual Regulation}

One argument against tort liability for architectural design is that if individuals want such features, they can contract for them and pay higher prices. This possibility was suggested by Judge MacKinnon in his dissent in Kline: "It is just too much, absent a contractual agreement, to require ... police patrol protection or its equivalent.... If tenants expect such

permitted to introduce evidence of assaults in the bathrooms of other casinos. Of course, a defendant should be permitted to distinguish, in appropriate cases, one set of bathrooms from another on the basis of design features.

292. A defense at trial may be allowed for a variance, given the particular circumstances (depending on the extent of the fine and the type of regulation at issue). Such a scheme also creates an incentive for the government to draft balanced crime prevention regulations-codes that would protect potential victims from crime and owners from high liability.

293. Consider this analysis of parking lots:

In the past, parking facility owners have hesitated to document their rationale for the specific security measures employed at a facility because they were afraid that such documentation would be used against them in any litigation. However, experience has shown that documentation that shows a thoughtful, rational approach to security planning is of substantial benefit in court.

SMITH, supra note 28; see also B.A. Glesner, Landlords as Cops: Tort, Nuisance \& Forfeiture Standards Imposing Liability on Landlords for Crime on the Premises, 42 CASE W. RES. L. REV. 679, 699 (1992) ("The voluntary assumption theory has been criticized for creating disincentives to provide security measures."); David W. Robertson, Negligence Liability for Crimes and Intentional Torts Committed by Others, 67 TUL. L. REV. 135, 142-44 (1992) (explaining the voluntary assumption theory and cases). 
protection, they can move to apartments where it is available and presumably pay a higher rental ...." 294

There is some reason to doubt that parties will make such contracts on their own, however, due to the hidden features of architecture. The problem is that there are informational asymmetries between landlords and tenants. Landlords have information about crime occurrences, many of which are not reported to the police. They also may have better knowledge about their premises and the crime risks created by the design (whether the risks be the result of latent construction features, low visibility, poor access controls, or some other factor). Because of these asymmetries, such bargaining might never take place or might take place in a suboptimal fashion. In striking a bargain, landlords-who, after all, want to get their apartments rentedmay hold back information concerning the security concerns in a neighborhood and the particular building from a prospective tenant. ${ }^{295}$

At the same time, some forms of architectural design are too expensive to impose on landlords and not sufficiently important to form the basis of a tort lawsuit or to be mandated across an entire jurisdiction. For those design features, solutions in contract might be appropriate because they leave the parties free to bargain about who pays for what and permit a carefully tailored solution to security in lieu of a one-size-fits-all regulation.

Fortunately, the law of contracts has developed mechanisms to remedy informational asymmetries. While a full survey of such techniques is beyond the scope of this Article, one possibility is to impose on landlords a duty to disclose, like that governing disclosure of latent defects for sellers. Government could regulate what landlords must disclose to prospective tenants regarding known occurrences of crime, access controls, lighting, and the like. Even simply requiring disclosure of the first item, known occurrences of crime, may induce landlords to take adequate precautions and can help tenants avoid risky situations. (This idea undergirds Congress's recent passage of the Crime Awareness and Campus Security Act, which requires higher education institutions that receive federal funding to keep track of and disclose crime statistics to members of the

294. Kline v. 1500 Mass. Ave. Apartment Corp., 439 F.2d 477, $492-93$ (D.C. Cir. 1970) (MacKinnon, J., dissenting); see also Cohen v. Southland Corp., 203 Cal. Rptr. 572,579 (1984) ("It is ... not unfair that patrons pay a few cents more for items they purchase from . . . a store and gain the assurance of reasonable protection against criminal activity while shopping there...."). In Richmond Medical Supply Co. v. Clifton, 369 S.E.2d 407 (Va. 1988), the court upheld a theory of liability based on express contract when the owner failed to replace a defective exterior door that gave burglars entrance. The trial court had dismissed the case on the ground that landlords did not have a duty to provide security, but the supreme court held that the tort duty-ofcare precedents were inapplicable to a contract theory.

295. Even victims of crime are not always forthcoming about their experiences, so the market in information is imperfect. However, landlords tend to have a much larger set of information than do individual tenants. 
campus community and prospective students. $)^{296}$ The failure to disclose such information could make a lease contract voidable at the option of the tenant, authorize the withholding of rent, and perhaps give rise to modest damages if crimes occur.

Should government wish to create incentives for landlords to disclose even more information, it could adopt a series of penalty defaults-such as making a landlord responsible for half of the damages from a crime on the premises-and the defaults could be removed upon a sufficient showing either of the landlord's disclosure of information or of the victim's negligence (assessed from the standpoint of a tenant who did not have such information). ${ }^{297}$ Government can also go beyond requiring disclosure of information to deem lease contracts voidable for failure to meet the housing code, and also provide for modest liquidated damages. Note that if the tenant is the better bearer of these crime prevention expenses, the landlord could write a lease contract explicitly to shift the burden, through waiver clauses, to the tenant. The information-forcing role of the contractual scheme would still be maintained. ${ }^{298}$

Some of the architectural designs discussed in Part I generate positive externalities for nonsignatories to the contract. When landlords take security precautions, they dissuade tenants from moving to an inefficient self-help system - such as staying indoors. Architectural precautions taken by a landlord may also enhance natural surveillance and decrease the fear of crime more generally in the neighborhood, thus providing benefits that do not accrue solely to a tenant. This externality cannot be captured in a contract. Landlord prevention can also take advantage of economies of scale (lighting that protects several tenants, common windows, and other

296. See 20 U.S.C. $\S 1092$ (f) (1994). Proponents of the Act argued that the reporting requirements would induce universities to take better precautions and would guide students in the selection of schools. See The Crime Awareness and Campus Security Act of 1989: Hearing on H.R. 3344 Before the House Subcomm. on Postsecondary Education of the House Comm. on Education and Labor, 97th Cong. (1990) (statement of Howard Clery). Some jurisdictions have held landlords liable in tort for the failure to wam tenants of criminal activity. See O'Hara v. W. Seven Trees Corp. Intercoast Mgmt., 142 Cal. Rptr. 487, 491-92 (Ct. App. 1977) (upholding a claim where the landlord knew of past rapes in the apartment complex but assured the prospective tenant of its safety without disclosing the prior rapes); BATES \& DUNNELL, supra note 276, at 46 (noting that failure to warn "has developed as an emerging concept in premises security lawsuits" and that "the failure to wam tenants of criminal activity can lead to a strong claim in premises security liability").

297. See Ian Ayres \& Robert Gertner, Filling Gaps in Incomplete Contracts: An Economic Theory of Default Rules, 99 YALE L.J. 87, 91-93 (1989) (explaining penalty default rules). This type of modification to default rules is one that can be generally applied outside of landlord-tenant relationships, such as in residential and commercial property sales. However, informational asymmetries are not likely to be as large in such settings, as the private sector may generate such information on its own.

298. One court has suggested that a waiver clause would release the landlord from liability for crimes. Cooke v. Allstate Mgmt. Corp., 741 F. Supp. 1205, 1207-08 (D.S.C. 1990). To prevent boilerplate waivers, a court could insist on explicit proof of actual bargaining over this term, such as through lower rents. 
features that enable natural surveillance) that would be impossible or inefficient for individual tenants to undertake or to require in contracts with landlords. If these externalities are sufficiently great for a particular type of precaution, a contractual scheme will not be appropriate and heavier inducements for precautions, such as tax breaks, should be used. ${ }^{299}$

A different point about externalities counsels against using contracts: Because the poor have less purchasing power, they are likely to disregard the information disclosed by landlords. A contract strategy might only give relatively wealthy tenants architectural protections. In such a circumstance, crime could be displaced from the wealthy to the poor. Again, one rationale of systemic and pervasive regulation of architecture is to avoid such negative externalities. A limited contractual scheme could, under certain conditions, exacerbate them.

I now turn to some ways in which criminal law can encourage architectural precautions that prevent crime.

\section{Government as Enforcer}

\section{Regulation of Places of Crime}

Government employs both civil and criminal processes to control private land use. These techniques have been used for many years: Nuisance and forfeiture were used to close down saloons before and during Prohibition. ${ }^{300}$ These tools can be adapted to focus on architectural considerations relating to crime prevention. For example, ample evidence suggests that decaying and abandoned buildings are breeding grounds for crime. To bring about better design, government can threaten to condemn or forfeit such property or to eliminate the place where congregation occurs. Such techniques can also reduce the perception that crime is rampant and bring more people outdoors. That, in turn, enhances natural surveillance.

Jurisdictions have begun experimenting with nuisance abatement programs. These programs threaten landlords with seizure of property unless the owners act to prevent the particular nuisance, which is more often than not drug dealing. Most of these statutes allow for the government or residents to bring a civil suit, and the primary sanction is an injunction to

299. Tax breaks and direct government spending will also spread the costs of architectural improvements over a wider segment of the population and minimize the risk that rents will increase.

300. Annotation, Constitutionality of Statute Providing for Forfeiture of Property upon Which Intoxicating Liquor Is Manufactured or Sold, 10 A.L.R. 1591 (1921); Henry Schofield, Equity Jurisdiction To Abate and Enjoin Illegal Saloons as Public Nuisances, 8 ILL. L. REV. 19 (1913). 
abate the nuisance ${ }^{301}$ In addition, some statutes provide for temporary or permanent closure of property and recovery of monetary damages. ${ }^{302}$

Eviction laws follow a similar path. New York's Bawdy House Law, for example, states that any owner or tenant within 200 feet of property used for illegal activity can serve written notice on the landlord requiring eviction of the tenant engaged in such conduct. ${ }^{303}$ New York City also recently implemented a padlock program whereby premises with illegal activity would be locked and closed. ${ }^{304}$ The Padlock Law provides the police commissioner with the authority to order the discontinuance of

301. See, e.g., ALA. CODE $\$$ 6-5-155.2 (Supp. 2000); ARIZ. REV. STAT. $\$ 12-991$ (Supp. 2000); DEL. CODE ANN, tit. 10, \$ 7105 (1999); D.C. CODE ANN. \$ 42-3602 (2001); UTAH CODE ANN. § 78-38-9 (Supp. 2001); VA. CODE ANN. \$ 18.2-258.01 (Michie 1996); W. VA. CODE $\$ 60 \mathrm{~A}-4-403 \mathrm{a}(2000)$. Early common law refused to permit such actions, reasoning that the lease was a conveyance that transferred all power of control to the tenant. E.g., City of St. Louis v. J.E. Kaime \& Brother Real Estate Co., 79 S.W. 140 (Mo. 1904); New York v. Corlies, 2 Sand. Ch. 301 (N.Y. 1848). These rules have been modified both by statute and common law. See, e.g., R.I. GEN. LAWS \& 11-30-7 (2000) (providing an example of statutory modification); People $v$. Schriber, 310 N.Y.S.2d 551, 552 (App. Div. 1970) (providing an example of common-law modification).

Some of these statutes apply only to drug-related crimes, See, e.g., ALA. CODE § 6-5-155.2; Del. CODE ANN. tit. 10, § 7104; VA. CODE ANN. \$ 18.2-258.01; W. VA. CODE $\$ 60 A-4-403 a$. Others apply to a wide variety of crimes. See ARL. REV. STAT. \$ 12-991 (applying to the use of residential property in committing any crime); FLA. STAT. ANN. \& 893.138 (crimes involving drugs, prostitution, stolen property, or gangs); UTAH CODE ANN. § 78-38-9 (drug-, gambling-, prostitution-, and gang-related crimes); WIS. STAT. $\$ 823.113$ (Supp. 2001) (dng- and gangrelated crimes).

302. See, e.g., DEL. CODE. ANN. tit. 10, $\$ 7105$ (closure of property); Fla. STAT. ANN. $\S 893.138$ (same); WIS. STAT. $\$ 823.113$ (same). However, to recover monetary damages, some statutes require that the owner knew or reasonably should have known about the nuisance. See, e.g., ARIZ. REV. STAT. \$ 12-991. Of these statutes that permit closure of the property, some limit such closure to one year, FLA. STAT. ANN. $\S 893.138$, while others allow for an undefined duration, WIS. STAT. $\$ 823.113$. In general, the statutes "do not typically result in the transfer of property ownership or the seizure of property" because owners work with city officials to abate the nuisance. Eck, supra note 105; see also Lorraine Green, Policing Places with Drug Problems: The Multi-Agency Response Team Approach, in CRIME AND PLACE, supra note 21, at 199, 200 (discussing Miami's nuisance strategy, which offers landlords low-interest loans to help get rid of drug dealers); Clarence Dickson, Drug Stings in Miami, FBI L. ENFORCEMENT BULL., Jan. 1988, at 1 (same); Bill Miller, Owners of Troubled Properties Targeted; U.S. Suits Seek To Seize CrimeRidden Buildings, WASH. POST, July 27, 2000, at J3 (noting that prosecutors have filed suits claiming inadequate lighting and security).

303. See N.Y. REAL Prop. ACTS. LAW § 715 (McKinney Supp. 2001); Cadwalader, Wickersham \& TAFT, A CIVIL WAR: A COMMUNITY LEGAL GUIDE TO FIGHTING STREET DRUG MARKETS 147-48 (1993) (discussing the Bawdy House Law). Cadwalader believed that nuisance laws were so important to fighting crime that the firm celebrated its bicentennial anniversary with publication of this book, with sample model complaints that residents could file in court.

304. NEW YORK CITY, N.Y., ADMIN. CODE $§ \$ 10-155$ to -156 (1996). In order for the police commissioner to proceed under the Padlock Law, two arrests must take place inside the targeted building, with at least one of these arrests resulting in a conviction. Then, a third "triggering" arrest must take place inside the building, and all three of these arrests must occur within one year. See CADWALADER, WICKERSHAM \& TAFT, supra note 303, at 47-49 (describing the Padlock Law); William J. Bratton, The New York City Police Department's Civil Enforcement of Qualityof-Life Crimes, 3 J.L. \& POL'Y 447, 455-56 (1995) (same). Michigan also has a somewhat similar Padlock Act. See MICH. COMP. LAWS ANN. $\$ 600.3801$ (West 2000). 
certain criminal activity within a building or to order the closing of the building to the extent necessary to abate the nuisance.

Oakland recently launched a program that focused on places rather than on individual offenders. Under this approach, city officials would inspect properties identified as drug nuisance areas, enforce building codes against such properties, and force landowners to maintain and clean them. ${ }^{305}$ The approach has been used over 2000 times with striking success. At least seventy percent of the time, city officials find housing violations and force compliance by the landlord. A study of the Oakland program found that those sites in which it was used had the greatest crime reduction-an amount fifteen percent greater than other areas of the city. The study found that the program also had a geographic halo effect: Crime dropped not only in the units targeted by the police, but also in neighboring units. It further found that major improvements to the physical infrastructure of the properties occurred after the program was implemented.

In addition to nuisance complaints, prosecutors can also bring forfeiture actions against places known to be used in criminal activity. The burden of proof is high, ${ }^{306}$ but such burdens can be advantageous if a jurisdiction believes that the nuisance power can be invoked by too many people or imposes too many burdens on innocent owners. Traditional forfeiture statutes did not attack the place of crime, as they targeted properties that were purchased with the proceeds of crime (some of these might also be places where crime takes place; others, however, may not) ${ }^{307}$ By contrast, more recent federal law permits forfeiture of real property that is used, or is intended to be used, to commit certain drug offenses. ${ }^{308}$

One large difference between forfeiture and nuisance concerns knowledge of the owner. Forfeiture laws require that owners know illegal

305. The data in this paragraph can be found in Green, supra note 302, at 199-213, and John E. Eck \& David Weisburd, Crime Places in Crime Theory, in CRIME AND PlaCE, supra note 21 , at 1,20. Another study of San Diego landlords found that crime dropped when code inspectors and police officers met with landlords after their tenants were arrested on drug charges. See JOHN E. ECK \& Julie Wartell, Reducing Crime and DRug Dealing by Improving Place MANAGEMENT: A RANDOMIZED EXPERIMENT (Nat'l Inst. of Justice, Research Preview, Jan. 1999).

306. The burden of proof in forfeiture proceedings was recently changed through legislation. See Civil Asset Forfeiture Reform Act of 2000, Pub. L. No. 106-185, § 2(c), 114 Stat. 202, 205-06 (codified at 18 U.S.C.A. $\$ 983$ (c) (West Supp. 2001)). The government must now establish, by a preponderance of the evidence, that property was used or was intended to be used in the commission of a drug offense before it is subject to forfeiture. This burden of proof is still lower than that in a criminal trial, and no convictions are required.

307. Unlike forfeiture of proceeds of a crime, which has no limitations because such proceeds are not "fines" but rather "fruits," the Constitution limits forfeiture of property used in the commission of a crime. The Supreme Court recently determined that both civil and criminal forfeitures (other than those of proceeds) constitute punitive fines and are therefore limited by the excessive fines clause of the Eighth Amendment. Austin v. United States, 509 U.S. 602 (1993); Alexander v. United States, 509 U.S. 544 (1993).

308. 21 U.S.C.A. $\$ 881$ (West Supp. 2001). 
conduct is occurring on their premises, ${ }^{309}$ nuisance laws, by contrast, generally do not. When the government is better situated than a landlord to know that criminal activity is taking place in an apartment, nuisance law may be preferable because it increases the flow of information to the landlord (who can then take action to avert closure or seizure of the building).

\section{Criminal Regulation of Owners of Places}

Some statutes already subject the owner of a dwelling that is used by drug dealers or drug users to criminal penalties. ${ }^{310}$ The federal code, for example, provides for criminal sanctions against an owner or occupier who knows premises are being used for narcotics activity under a law commonly referred to as the "crack-house statute." ${ }^{311}$ Criminalizing use or possession is unlikely to be effective by itself because the owner of the property may not be present and because, "[w]hen police raid these crack houses, the dealers and users can easily dispose of the drugs, thus avoiding arrest." 312 Three important limits generally confine the use of these statutes. First, the crimes must be proven "beyond a reasonable doubt." Second, many of these statutes specifically require knowledge on the part of the owner. ${ }^{313}$ And third, the courts have interpreted some statutes to require more than a single instance of drug activity. ${ }^{314}$

309. The federal statute explicitly provides that an "innocent owner's interest in property shall not be forfeited under any civil forfeiture statute." 18 U.S.C.A. $\$$ 983(d)(1) (West Supp. 2001). Another difference concerns the remedy. If an owner is prone to allowing crime to continue, forfeiture, which permanently strips ownership of property away from an owner, is a better solution than nuisance, which often leads to only temporary closure of the property.

310. E.g., CAL. HEALTH \& SAFETY CODE $\$ 11366.5$ (1991); GA. CODE ANN. § 16-13-42 (1999); MD. ANN. CODE art. 27, \& 286(a)(5) (1996 \& Supp. 2000); OHIO REV. CODE ANN. $\S 2925.13$ (Anderson 1996 \& Supp. 2000); S.D. CodifiED LAws \& 22-42-10 (Michie 1998); WASH. REV. CODE $\$ 69.53 .010$ (1997). Some statutes also criminalize the conduct of owning a dwelling that was involved in prostitution. E.g., ARIZ. REV. STAT. $\$ 13-3208$ (2001); D.C. CODE ANN. § 22-2713 (1996 \& Supp. 2001); MICH. STAT. ANN. § 750.454 (Michie 1991) (prohibiting leasing). The criminal sanctions applicable under these state and federal statutes vary from misdemeanor to felony penalties and often include jail time and fines.

311. 21 U.S.C. $\$ 856(a)(2)$ (1994). This section "is designed to apply to the person who may not have actually opened or maintained the place for the purpose of drug activity, but who has knowingly allowed others to engage in those activities." United States v. Chen, 913 F.2d 183, 190 (5th Cir. 1990); see also United States v. Sturmoski, 971 F.2d 452, 461-62 (10th Cir. 1992) (describing the section as going "beyond the proscriptions found in other statutes relating to possession and manufacture of controlled substances and actually criminaliz[ing] a particular defendant's use of property").

312. 132 CONG. REC. S13,741 (daily ed. Sept. 26, 1986) (statement of Sen. Chiles).

313. E.g., CAL. HEALTH \& SAFETY CODE $\$ 11366.5$; GA. CODE ANN. $\$ 16-13-42$; OHIO REV. CODE ANN. § 2925.13; WASH. REV. CODE § 69.53.010. A requirement of knowledge has also been read into another statute where such a requirement was not explicitly stated. See State v. Stone, 467 N.W.2d 905, 906-07 (S.D. 1991) (interpreting S.D. CODIFIED LAWS \& 22-42-10).

314. See, e.g., Barnes v. State, 339 S.E.2d 229, 232 (Ga. 1986); Hunt v. State, 314 A.2d 743 (Md. Ct. Spec. App. 1974); Howard v. State, 815 P.2d 679, 683 (Okla. Crim. App. 1991). 
The threat of criminal penalties might induce a landlord to take architectural precautions to avoid criminal liability down the road. However, criminal sanctions, like forfeiture, are only modest inducements to take such precautions. Their stronger effect may be to encourage natural surveillance as neighborhoods get cleaner and safer, enabling architecture to work more effectively. As with all law enforcement solutions, however, the costs can be significant.

\section{Criminal Regulation of Perpetrators and Others}

\section{a. Crimes Against Neighbors and Networks}

Architectural concepts such as natural surveillance demonstrate that certain forms of crime pose special dangers to society. These crimes target social networks and make it more difficult for interaction to develop. ${ }^{315}$ Examples are hate crimes, rape, and some other forms of violent crime that have the effect of creating stratification among divergent social groups. Others are some more minor crimes, from assaults to public urination. People who are afraid of being hurt do not venture outdoors, and so even a garden-variety assault, given the circumstance, may undermine natural surveillance. Similarly, if the sights and smells in a neighborhood are not pleasing, it is unlikely that people will walk the streets. Offenses that are considered trivial can thus have more dramatic consequences. Instead of focusing on the act involved in the commission of a crime, I am arguing that its probable consequences are relevant when apportioning punishment. One such consequence concerns complementarity. Complementarity is the economic notion that two products "go together" and that a price decrease in one will lead to additional consumption of the other. If offenses such as public urination have low "prices" attached to them, more of these offenses will be committed, and these may prompt additional, more serious offenses. The apportionment of sentences and of investigative and prosecutorial resources should take into account consequences of crime and, in particular, its harm to social networks.

A few crimes even more explicitly target neighbors who act as good citizens. For example, when a neighbor is assaulted while attempting to break up a street fight, that assault has repercussions on natural surveillance more generally. Similarly, when a witness to a crime is threatened, other witnesses can be deterred from assisting law enforcement in later cases. For this reason, obstruction of justice statutes play a crucial role in protecting natural surveillance practitioners. Although such statutes do not protect practitioners until the police are involved, their existence can provide some

315. Katyal, supra note 3, at $1087-90$ (discussing the crime of targeting networks). 
comfort to bystanders. Bystanders need to know that the law will protect them if need be-even if they do not actually invoke formal process. Bystander intervention will be more likely as the possibility for protection increases.

\section{b. Crimes Against Architecture}

Some crimes directly interfere with architecture. A historical example concerns the crime of burglary, defined at common law to require "breaking" and "entering." 316 Criminal law students often wonder why breaking and entering should be a special crime, when the laws against robbery, trespass, and assault cover the brunt of cases. Some venture the answer that breaking and entering serves as an inchoate crime to cover circumstances in which the perpetrator was not able to abscond with any items. But the problem with that rationale is that attempt liability covers many of the inchoate contexts. Others venture that the law wants to protect residents from having their houses invaded, even by individuals who do not wish to steal or maim. But, again, the law against trespass generally serves this purpose. The prohibition against breaking and entering, however, could have a unique function: to protect access barriers. If a criminal "breaks" through such barriers to the point where "entry" is achieved, others can follow into the premises. ${ }^{317}$ The law, perhaps unconsciously, reflects the belief that access barriers need special protection, to prevent criminals from weakening them and creating the possibility of repeated attacks against a target.

The common law of burglary intentionally provided a direct incentive for landowners to take precautions and strengthen access barriers: It was not burglary when a burglar crawled through an open window or went through an open door. Blackstone defined burglary as "at least by breaking, or taking out the glass of, or otherwise opening, a window; picking a lock, or opening it with a key." 318 "But," Blackstone continued, "if a person leaves his doors or windows open, it is his own folly and negligence; and if a man enters therein, it is no burglary." ${ }^{319}$ As one English court put it, "if a

316. COKE, supra note 58 , at 63 ("A burglar is by the common law a felon, that in the night breaketh and entreth into a mansion house of another ....").

317. This rationale does not explain all of burglary, as burglary did not always require destruction of an access barrier. If someone opened an unsecured door or window, it would constitute burglary. See 1 MATtHew Hale, Pleas OF THE Crown 68-70 (London, Richard Tonson 1678).

318. 4 WILLIAM BLACKSTONE, COMMENTARIES *226.

319. Id.; see also Gaddie v. Commonwealth, 78 S.W. 162,163 (Ky. 1904) ("[T]here is no breaking where the entering is through ... pushing further open a door partly open, or raising a window partly raised ...."); 1 HALE, supra note 317, at 68 ("If $A$. enter into the house of $B$. in the night, by the doors open, and breaks open a chest, and takes away goods without breaking open an inner door, this is no burglary ...."). 
man choose to leave an opening in the wall or roof of his house, instead of a fastened window, he must take the consequences." ${ }^{320}$ The limitation on common-law burglary was also based on a sort of "attractive nuisance" theory, that the "manifest carelessness of the householder" in leaving a window open "tempts the passer-by to enter." ${ }^{321}$ In other words, the common law of burglary was based in part on the desire to encourage potential victims of crime to take precautions and to use architecture to prevent easy access.

The access point suggests that crimes against architecture should be punished because deterring those crimes will prevent the commission of more serious ones. It also suggests that if certain crimes can be easily foiled by architecture, law enforcement might not want to invest as many resources in fighting those crimes. This is, as we have seen, one explanation for the elimination of the nighttime requirement in the crime of burglary. ${ }^{322}$ Crimes that directly interfere with natural surveillance should also be singled out for special penalties. Destroying the lighting around a building is one obvious example. Another would be attempts by criminals to bring smoke-belching trucks onto a street before robbing an establishment. ${ }^{323}$

\section{c. Law Enforcement Priorities}

Another way to encourage development of architectural solutions is to adopt a policy whereby prosecutors and police give priority to cases in

320. Rex v. Spriggs, 174 Eng. Rep. 122 (C.P. 1834).

321. State v. Lapoint, 88 A. 523, 524 (Vt. 1913).

322. See supra text accompanying note 58 .

323. These examples underscore that architecture alone will not stop crime. Law can go further and place minimal legal duties on bystanders to instill a norm of being a watchful neighbor. Whether law should create an affirmative duty to report a crime is a difficult question, replete with moral and social consequences that this Article cannot resolve in the short space remaining. Yet the importance of natural surveillance provides a modest argument in favor of imposing a duty to report criminal acts and to punish the failure to report with nominal fines. The idea is that bystanders serve as cheapest cost avoiders: They are more responsive to minimal legal sanctions than criminals are to larger ones. Placing liability on them may thus bring about more preventive action by the public and the police.

Bystander intervention requirements are also helpful in that they provide an excuse for monitoring. At present, if a neighbor is only partially convinced that he is watching a crime take place, he may refrain from calling the police out of fear of retaliation by the supposed perpetrator. But once the law imposes a duty, the neighbor's call to the cops is more understandable-even, perhaps, to the supposed perpetrator. Legal duties, here and elsewhere, sometimes provide an excuse, a cover, for conduct that could risk social disapproval.

Some jurisdictions have used law to facilitate intentional surveillance as part of a design strategy. For example, some localities have passed laws requiring convenience stores to have two clerks on duty at all times. Casteel \& Peek-Asa, supra note 51, at 110,113 (finding that this strategy likely decreases crime but that more controlled research is required). Private contracts, or even default rules in law, could go even further and place requirements on store clerks to detect and report thefts by holding them liable for a small percentage of the theft. If such a scheme is used, liability should not be draconian; the idea is simply to reinforce attitudes toward intervention and reporting. 
which owner-victims used appropriate design before the crime was committed. If a victim of crime did not take adequate architectural precautions, that case would be relegated to the back of the list. This is a strategy I have proposed in the context of computer crime, with the aim of getting victims of crime to take adequate architectural and other precautions before an offense occurs. ${ }^{324}$ It is designed to provide incentives not only to victims, but also to law enforcement. If police know that the only way to have freedom to prioritize cases as they see fit is to have a series of victims who have used adequate architecture, they will then warn owners to use such techniques.

Many, for good reason, would find it inappropriate to apply such prioritization strategies to situations in which victims suffer physical harm. But on this view, prioritization could still be applied to those crimes in which no physical violence takes place, such as damage to property and theft. ${ }^{325}$ If a perpetrator, in the course of committing a property offense, also engages in an act of physical violence to a human being, however, the prioritization strategy would be discarded. Under this system, marginal deterrence against crimes of violence-presumably a goal of those who would limit prioritization to crimes against property-is actually enhanced. A perpetrator can commit a property offense at less risk of investigation and prosecution, but the risks increase once that crime turns to one of violence.

\section{Community Policing}

The recent move toward community policing has potential synergies with architectural solutions to crime. Community policing refers to techniques of law enforcement that locate police directly in communities, where they are responsive to local concerns and pursue local agendas. The idea is to prosecute those cases that the community feels deserve sanction, instead of relying on standardized instructions from a centralized headquarters. When done correctly, community policing brings more people out onto the streets, where they can perform their natural surveillance role. It does so by creating respect for law enforcement, which reduces the fear of threats on the street (whether from criminals or police officers).

As the New Jersey Safe Neighborhoods program showed, architectural techniques work together with community policing. Effective community

324. Katyal, supra note 3 , at 1077-82.

325. The strategy will be most desirable for inexpensive forms of architectural precaution. As the precautions become more costly, prioritization will become so regressive that it should be abandoned. Similarly, if the strategy disadvantages the poor, it might only be applied to commercial establishments. Prioritization may also provide an incentive for criminals to attack areas with fewer precautions, so the strategy should be employed in limited circumstances in which the precautions are easy to adopt and hard to observe and where law enforcement is costly. 
policing requires advice from residents about unsafe areas and about ways to respond to the problem, and effective architectural design benefits from law enforcement's views about architectural techniques. ${ }^{326}$ A program in Rogers Park, Chicago, brought residents and police together and generated a series of design recommendations that would reduce the crime rate and help foot patrols function better ${ }^{327}$ Even the process of developing an architectural plan fosters community; when residents of Miami's Coconut Grove neighborhood began consideration of a plan to take down their individual fences and create more visibility and diversity of land use, the process created common understandings and sharing. ${ }^{328}$

The techniques discussed in Part $I$ are designed in part to give communities greater roles in order maintenance. Yet they also make policing easier by reducing opportunities for escape and reducing tensions in a community. Moreover, when communities feel they have more control over the criminal process, they may involve law enforcement in different ways. They will not have to fear that every call to the police will result in an arrest; instead they may ask the police to serve as peacekeepers. Such techniques contribute to public order and reduce the fear of crime.

\section{SOME RISKS OF ARCHITECTURE}

When theorists such as Jane Jacobs began formulating design principles that would deter crime, their proposals generated a wave of criticism. Hard architecture, it was thought, looked draconian and gave an appearance redolent of jail cells. New advances in technology, however, liberate us from a choice between high crime and life in a fortress. Concrete can be attractively stained to enhance visibility, access barriers can be subtle and pleasing to the eye, and plastics can be employed that appear to be welcoming but are actually stronger than steel. For that reason, the aesthetics argument is not as powerful as it once was. However, there are

326. See DAN Fleissner \& Fred heinzelmann, CRIMe PREVEnTION THROUGH EnviRonmental DeSIGN AND COMmUNity POLICING (1996), http:/www.ncjrs.org/txtfiles/ crimepre.txt; supra note 240 . In 1973, Hartford, Connecticut, adopted a program to couple community policing with changes to the environmental design of two neighborhoods. Burglary dropped by approximately fifty percent, whereas neighborhoods that did not use architectural techniques had no drop in their crime rates. The study also revealed a $27.5 \%$ reduction in incidence of street crime. GARDINER, supra note 30, at 67.

327. Michelle Anderson et al., A Defensible Space Project: Deterring Crime and Building Community in Rogers Park, at http://www.luc.edu/depts/curl/pub/defense.html (last visited Nov. 29, 2001).

328. According to one radio report, Coconut Grove residents destroyed "the psychic walls" that were dividing them and came together as a result of the project: "Before starting the crimefighting project, they went their separate ways and hardly spoke to each other. 'But that's all changed.... Now, I mean, it's unbelievable the difference. We pretty much talk on the phone practically almost every day. Everybody has become friends." Neighborhood Fights Crime by Opening Up (NPR radio broadcast, May 29, 1994) (quoting a five-year Coconut Grove resident). 
four remaining general criticisms to consider. The first concerns the risk to individual privacy posed by natural surveillance. The second is a broader criticism about extending the sphere of social control beyond the state. The third is an argument about whether architectural solutions reduce crime or simply displace it. And the fourth underscores how rules to harness design might produce suboptimal types of architectural protections against crime.

In this Part, I explore these criticisms, though again my goal is not to answer them in full. The objections are sufficiently weighty to counsel the government against employing architectural solutions in some circumstances. But one important global response to the criticisms must be kept in mind: They plague law enforcement as well. Extensive law enforcement methods threaten privacy, as any person who has read a Fourth Amendment case knows. ${ }^{329}$ Intrusions by the government can be of special danger in that they invoke the coercive apparatus of the state, manifested in the potential for imprisonment. Law enforcement can also displace crime from one area to another or lead to the substitution of one type of crime for another. Reliance on conventional policing can also induce owners to take suboptimal architectural protections. Accordingly, government should not use architecture everywhere to prevent crime, although it should consider design concepts in an array of situations before resorting to increases in law enforcement.

\section{A. Threat to Privacy}

At first blush, natural surveillance appears to be in tension with a commitment to privacy. In this Section, I outline some reasons why government can both be faithful to privacy interests and support natural surveillance and similar crime reduction techniques.

First, without government attention to architectural solutions, individuals will embrace architectural solutions of their own. At times, architectural solutions to crime will be inevitable; the real questions concern what type of solutions will be picked, and who will pay the bill. The use of private solutions can pose even more severe risks to privacy; a closed-circuit television camera that looks out onto public space is one good example. Without careful attention to violations of privacy by private actors, government neutrality can perversely restrict privacy instead of

329. The cost of poor architectural design can be an increase in the number of police and an increase in privacy intrusions. See supra notes $98-99$ and accompanying text (describing the Van Dyke housing project, where natural surveillance was low and the police were therefore callous toward privacy). 
augmenting it. In these settings, government regulation of architecture to prevent crime might enhance privacy. ${ }^{330}$

Without better design, individuals will use other suboptimal means of self-help as well. The most instinctive approach is simply to stay indoors and avoid contact with the outside world. Recall what happened to the St. Louis Pruitt-Igoe project: The architectural design created hidden stairwells where crime festered and forced residents into their individual apartments. ${ }^{331}$ Government should steer individuals and businesses away from these coping mechanisms by, for example, creating semipublic spaces that mediate the tension between an atomized group of individuals and a collective and undifferentiated mass.

Second, many individuals who might be helped by architecture already lack privacy, as they live in conditions where intrusion is common and crime is rampant. This is one reason why a paradigmatic application of these architectural concepts is inner-city housing that suffers from high crime. Privacy in America today is a luxury good that the poor often lack the resources to secure. Privacy is about controlling the boundaries of one's exposure, and if a person can be attacked by others, or if her property can be invaded, it is a fundamental violation of these boundaries. Far from destroying privacy, government can help secure more privacy for the poor through architectural techniques such as increasing territoriality and controlling private space.

A third point is sufficiently complicated that I offer it only tentatively. The argument is that architecture can reinforce the essential value of privacy by creating public spaces that encourage social interaction. Groups of atomized individuals who live and think alone do not fulfill the aspirations of privacy. Privacy should be valued precisely because it contrasts with a public life. It cannot be valued as highly on its own, because an essential purpose of privacy is to permit individuals to take lessons from public life and reflect upon them in conditions of relative isolation, where candor and deliberation are at their height. Put differently, many privacy enthusiasts have remarked that privacy is necessary to ensure a vibrant public life, because private space facilitates the development of a public persona. ${ }^{332}$ But the converse could be true as well: The realization of one's privacy may depend on one's ability to develop a public persona.

My argument presumes that an overriding goal is to get rid of crime, but those who disagree can still endorse architectural strategies while also

330. There are also distributional consequences to nonintervention; a free market may induce more affluent communities to use architectural protections and possibly externalize crime onto other communities, thereby invading the privacy of the latter.

331. See supra text accompanying note 97.

332. E.g., GOFFMAN, BEHAVIOR, supra note 34, at 38-39 (discussing how "involvement shields" permit individuals to hide in private to display fully reactions to news received in public); JEFFREY ROSEN, THE UNWANTED GAZE 11-12 (2000) (making a similar observation). 
arguing to reduce the level of law enforcement. If society concludes that a degree of crime is not harmful, some crime can be excused on a random basis, or sentences for particular crimes eliminated altogether. And if destabilization of the law is a goal in a particular community, the above analysis illuminates a way to resist the force of law: building places where surveillance is minimal, access is plentiful, and territoriality is weak.

\section{B. Social Control}

A major theme of Michel Foucault's incisive book, Discipline and Punish, concerns the evolution of methods of social control. He showed how punishment moved away from inflicting pain on the body toward creating a system where enforcers could always view what people were doing-"eyes that must see without being seen." ${ }^{333}$ Central to Foucault's analysis, though underappreciated by legal scholars, is a claim about architecture.

Foucault's work illustrated how earlier systems of punishment depended on marking the body of the offender and creating a public spectacle, a spectacle that would reinforce law-abiding behavior in the citizenry. More modern systems, by contrast, substituted this spectacle for a regime of surveillance. Architecture played a critical role in perfecting this new regime. Foucault explained how its "ideal model" for the plan of buildings and cities was the military camp: "The geometry of the paths, the number and distribution of the tents, the orientation of their entrances, the disposition of files and ranks were exactly defined; the network of gazes that supervised one another was laid down., ${ }^{334}$

Foucault relied on two examples to demonstrate this form of surveillance. The first concerned measures to control the spread of the plague in the seventeenth century. The city was partitioned, and each street was placed under the control of a syndic. Everyone was ordered to stay indoors, and the syndic locked each door from the outside. Observation posts were erected to watch the streets, and "[i]nspections function[ed] ceaselessly. The gaze [wa]s alert everywhere." 335

Foucault's second example was Jeremy Bentham's famous Panopticon. The initial conception of the Panopticon dates back to a series of letters Bentham wrote in 1787, which began with the following invocation:

333. MiChEl FoUCAUlT, DisCIPLINE AND PUNISH 171 (Alan Sheridan trans., Vintage Books 2d ed. 1995) (1975).

334. Id. "The perfect disciplinary apparatus would make it possible for a single gaze to see everything constantly ...; a perfect eye that nothing would escape and a centre towards which all gazes would be turned." Id. at 173; see also Katyal, supra note 4, at 2456-57 (discussing Foucault's views on the transformation of social control).

335. FOUCAULT, supra note 333, at 195. 
"Morals reformed-health preserved-industry invigorated-instruction diffused ... the gordian knot of the Poor - Laws not cut, but untied - all by a simple idea in Architecture!" ${ }^{336}$ Bentham's panoptic design arranged prison cells in a ring-shaped building surrounding a central tower. The cells were to be open to the tower and backlit, rendering the inmates constantly visible to the guard in the tower. The purpose of the Panopticon was to use surveillance to control behavior: "[T] he more constantly the persons to be inspected are under the eyes of the persons who should inspect them, the more perfectly will the purpose of the establishment have been attained," 337 To achieve this effect, Bentham proposed that power should be "visible," in that the inmate could always see the central tower from which he is spied upon, and "unverifiable," in that the inmate must never know whether he is being looked at during any one moment, but must realize that he may always be so. ${ }^{338}$

Foucault identified other applications of the Panopticon besides its use in the prison setting. These included treating patients in hospitals, instructing schoolchildren, supervising workers, and putting idlers to work in factories. ${ }^{339}$ Foucault's claim mirrored those of contemporary environmental psychologists about how architecture can shape tastes. When architecture "is no longer built simply to be seen ... but to permit an internal, articulated and detailed control[;] . . architecture ... operate[s] to

336. JeREMy BEntham, PANOPTICON; OR, THE INSPECTION House, at i (London, T. Payne 1791) [hereinafter BENTHAM, PANOPTICON] (emphasis altered). As these opening words suggest, Bentham's claim was all about architecture. Bentham's letters were full of technical details, such as the placement of windows in prisons, JEREMY BENTHAM, PANOPTICON: POSTSCRIPT; PART I, at 132-37 (London, T. Payne 1791), the width of passages, id. at 110-15, the types of doors and locks, id. at 107-09, the height of a proper inspection tower and the types of fences necessary, id. at 116-31, and the different construction materials that should be employed, $i d$. at 138-43.

337. BENTHAM, PANOPTICON, supra note 336 , at 3.

338. Id. (stating that since surveillance "during every instant of time" was "impossible," the next best "thing to be wished for is, that, at every instant . . . [a prisoner] should conceive himself to be" under observation); see also Bernard E. Harcourt, Reflecting on the Subject: A Critique of the Social Influence Conception of Deterrence, the Broken Windows Theory, and OrderMaintenance Policing New York Style, 97 MicH. L. REv. 291 (1998) (discussing Foucault's understanding of crime control).

339. FOUCAULT, supra note 333, at 205; see also Hugh Baxter, Bringing Foucault into Law and Law into Foucault, 48 STAN. L. REV. 449, 456 (1996) (reviewing ALAN HUNT \& GARY Wickham, TOWARds a Sociology of LaW as GovernanCE (1994)). For Foucault, in the Panopticon,

it does not matter who exercises power. Any individual, taken almost at random, can operate the machine... Similarly, it does not matter what motive animates him: the curiosity of the indiscreet, the malice of a child, the thirst for knowledge of a philosopher.... The more numerous those anonymous and temporary observers are, the greater the risk for the inmate of being surprised and the greater his anxious awareness of being observed.

FOUCAULT, supra note 333, at 202. 
transform individuals." 340 " Stones," for Foucault, "can make people docile and knowable." ${ }^{34 !}$

Foucault's keen observations on the power of architecture to extend the sphere of social control do not require abandoning the project of crime control through architecture. After all, architecture, regulated or not, will inevitably shape us in various ways. The safest form of architecture can be that which is publicly regulated and justified. Private architectural developments shape and modify behavior, too, and may do so on a more invidious scale than public ones. ${ }^{342}$ (This mirrors a criticism I have made elsewhere about Lawrence Lessig's views on the use of code in regulating cyberspace. $)^{343}$ The government labors under special constraints when it acts; it is subject to information disclosure laws (such as the Freedom of Information Act), and it is publicly accountable for its decisions in ways that private actors are not. Public manipulation of architecture can be more responsible and far more transparent than private decisionmaking. ${ }^{344}$ Indeed, if government used its power to alter physical environments, it might reduce the impulse of private bodies to do so.

Picking up again on the global response, another reason why Foucault's analysis should not counsel abandoning architectural solutions is that it equally-if not even more forcefully-indicts the alternative to architecture: conventional law enforcement. ${ }^{345}$ The public already acts as an arm of the state and has been assisting law enforcement for most of this country's existence. Consider, for instance, that over three-fourths of all arrests are due to reports by bystanders or victims. ${ }^{346}$ As we have seen,

340. FOUCAULT, supra note 333, at 172.

341. Id. The Panopticon "could be used as a machine to carry out experiments, to alter behaviour, to train or correct individuals." Id. at 203.

342. See Daniel B. Kennedy, Facility Site Selection and Analysis Through Environmental Criminology, 18 J. CRIM. JUST. 239, 249 (1990) (observing that private industry is currently using architectural strategies to prevent crime). Likewise, govemments that do not have open access to information pose special dangers when they employ architecture to shape behavior. For example, the former Soviet Union used architecture self-consciously to try to change attitudes. See ANATOLE KOPP, CONSTRUCTIVIST ARCHITECTURE IN THE USSR 7, 31-37, 144-50 (1985).

343. Katyal, supra note 3 , at 1103-06. This rejoinder does not fully resolve the problem, however, because some strategies discussed in Part II spur autonomous private architecture.

344. See, e.g., David H. Bayley \& Clifford D. Shearing, The Future of Policing, $30 \mathrm{LAW} \&$ SOC'Y REV. 585, 596 (1996) (observing that private security is not accountable to "all the people who might be affected by it"); Clifford D. Shearing \& Philip C. Stenning, Private Security: Implications for Social Control, 30 SOC. PROBS. 493, 497-98, 504 (1983) (discussing problems with private social control).

345. Many followers of Foucault have similarly argued that law enforcement is a system of private and public social control. E.g., WiLlIAM G. STAPLES, EVERYDAY SUR VEILLANCE (2000).

346. See Shotland \& Goodstein, supra note 37, at 9 . The first formal police department was not created until 1837 in Boston, and in the early nineteenth century it was neighborhoods that had the responsibility for reporting crimes to the town marshal. Other evidence suggests that private social control is now embedded. See Clifford D. Shearing \& Philip C. Stenning, From the Panopticon to Disney World: The Development of Discipline, in PERSPECTIVES IN CRIMINAL LAW 335, 346-48 (Anthony N. Doob \& Edward L. Greenspan eds., 1985). 
careful attention to design can enable more private control of public spaces. Governments can reduce the presence of police officers-a presence that is more coercive than the presence of architecture-as the ability of communities to self-protect increases.

This analysis will not persuade everyone. For many, crime prevention is simply not an important enough goal to justify greater government interference. Again, my aim is not so much to persuade such individuals that they should rethink their tolerance of crime as it is to suggest that the study of architecture can inform their understanding of the relevant policy decisions. Government is already making choices about crime through architecture when it builds housing projects, government offices, schools, embassies, and other buildings. Whether these choices by the government are conscious or not, there is much to be gained from public debate about them. Underlying this claim is a deeper point: Just as critical scholars have exposed how government inaction through law is itself a form of action, so too the government's decision to forgo using crime prevention strategies is a form of social control. It has meant, for example, that more affluent communities have been able to secure protection for their bodies and property while others have not. It is possible that government choices are causing a certain amount of crime via displacement to poorer communities. So even though architectural strategies have not formally been embraced everywhere, as long as they are embraced somewhere, their use may "regulate" faraway spaces. In this sense, the choice is not whether to embrace architecture, but how.

\section{Geographic Substitution}

A potential problem with architectural solutions to crime is that they may create geographic substitution; that is, offenses may simply be displaced to those locations with less architectural protections. If so, architecture is not necessarily reducing crime, it is shifting it. Of course, displacement may be a reason for government regulation of architecture when regulation achieves greater spatial uniformity of architectural precautions. Uniformity is one rationale for increased law enforcement in poorer areas, too, and standard policing runs similar risks of displacement. ${ }^{347}$ There are also other reasons why displacement does not require abandoning the project of reducing crime through architecture.

347. For example, a RAND study showed that when New York City increased the presence of police by forty percent in one precinct, it reduced street crimes in that precinct, but crimes in adjacent precincts increased. S. JAMES PRESS, SOME EFFECTS OF AN INCREASE IN POLICE MANPOWER IN THE 20TH PRECINCT OF NEW YORK CITY (1971); see also BURSIK \& GRASMICK, supra note 81 , at 17-18 (discussing studies showing geographic substitution following law 
First, several factors explain why the geographic substitution of crime as a response to architectural strategies will be only partial. ${ }^{348}$ Offenders generally do not travel far. More than thirty percent of burglaries occur within one half-mile of the offender's home. ${ }^{349}$ Distance imposes costs-the costs of perpetration rise, the risk of getting caught due to unfamiliarity with the area increases, and the criminal's certainty as to the outcome of the offense is reduced. For these reasons, some studies have found that targethardening measures do not always displace crime; rather, at times they reduce its overall level. ${ }^{350}$ Other studies suggest that rather than displacing crime, architectural protections might actually have geographic halo effects. $^{351}$

Second, if the architectural protection is not apparent from the outside of a structure, then geographic substitution will be avoided and overall crime reduced. Many devices, such as steel-reinforced doors, strong plastics, and the like are not discernible until a criminal has invested some energy and time..$^{352}$ These forms of precaution will thus increase expected perpetration cost and deter offenders without risking substantial displacement.

Third, displacement is often desirable. Many times an architectural precaution should be visible to deter offenders from attacking a target. Granted, these visible designs do run the risk of displacing crime to other areas, but concentrating crime into areas characterized by poor architectural

enforcement); George F. Rengert, Spatial Justice and Criminal Victimization, 6 JUST. Q. 543, 545 (1989) (same).

348. FOWLER ET AL., supra note 34, at 104 ("[I]f displacement of burglary occurred as part of the reduction of burglary" due to an architectural design plan in Hartford, Connecticut, "it did not occur in the most obvious places for it and the pattern was difficult to identify."); Patricia Allatt, Residential Security: Containment and Displacement of Burglary, 23 HOW. J. CRIM. JUST. 99,110 (1984) (presenting an empirical study finding that "while the upgrading of security for an entire area does have displacement effects there may still be a net saving in crimes committed"); Eck \& Weisburd, supra note 305 , at 1, 20 ("There is a growing body of evidence that suggests that displacement is seldom total and often inconsequential or absent.").

349. Van Soomeren, supra note 65, at 10 (detailing studies); see also JEFFERY, supra note 22, at 190-91, 201 (same).

350. Crime Prevention Through Housing Design, supra note 32, at 8 ; Clarke \& Field, supra note 104, at 88 (reporting that target hardening in Australian banks did not displace crime); Dickson, supra note 302, at 6 (" [D]isplacement is not occurring to any significant degree. Buying patterns are not easily reestablished; the infrastructure and support networks take time to rebuild."); Eck, supra note 105 (suggesting that barriers in Miami Shores, Florida, did not displace crime elsewhere); Grandjean, supra note 104, at 158 (finding that target hardening of some banks in Switzerland did not displace crime); Barry Poyner, Situational Crime Prevention in Two Parking Facilities, 2 SECURITY J. 96, 98-99 (1991) (presenting an empirical study of parking lot architectural protections, finding that their adoption in some parking garages did not displace crime to other lots); Spelman, supra note 154, at 483 (finding that boarding up abandoned buildings did not displace juvenile crime to other locations because the kids "were motivated primarily by the availability of easy opportunities").

351. See, e.g., Eck \& Weisburd, supra note 305, at 1, 20 (summarizing evidence).

352. See Ian Ayres \& Steven D. Levitt, Measuring Positive Externalities from Unobservable Victim Precaution: An Empirical Analysis of Lojack, 113 Q.J. ECON. 43, 44 n.2 (1998). 
design permits law enforcement to focus on fighting crime in those areas. Diffuse crime can be difficult to fight. Moreover, to the extent that design techniques have benefits that radiate beyond a single target (neighborhood street closures are a good example), the resulting increase in autonomous order enforcement will free up law enforcement to focus on other areas. Indeed, when one jurisdiction enhances its architectural precautions, it may upset the equilibrium in other areas, leading those others to adopt architectural measures as well.

The comparison of law enforcement to architecture highlights a broader substitution problem. Law enforcement can create substitution effects with respect to different offenses: If police begin a crackdown on heroin, for example, that may simply induce individuals to use other drugs for which penalties are not as strongly enforced. Architecture, however, generally works as a "wide-band" strategy; by creating visibility, it attempts to deter several types of crime at once. ${ }^{353}$ Natural surveillance, for example, does not simply constrain burglary, it also reduces assault, rape, murder, battery, drug sales, public urination, loitering, and other forms of incivility. As a result of their wide deterrence potential, architectural strategies can minimize negative substitution effects. But substitution is still possible. Criminals might, for example, react to architectural protections by increasing computer crimes. If substitution is widespread, and criminals can easily shift to new and unpredictable forms of crime, law enforcement might be preferable to architectural methods because architecture requires sunk costs that cannot be easily recouped. On the other hand, architecture precludes a wide variety of crimes, some of which are constant problems (such as burglary and assault), and can therefore help law enforcement focus on rapidly evolving challenges.

In sum, using architecture to control crime poses dangers, but law enforcement and, of course, crime itself have costs. The substitution risks and the dangers to freedom from the government's manipulation of architecture must therefore be assessed alongside the corresponding harms from the government's employment of law enforcement tactics.

\section{Suboptimal Architecture}

The final problem concerns whether government inducement of architectural protections might produce the wrong types of design. This problem takes two different forms. In the first, government regulation can lead to counterproductive architecture that expresses fear. In the second, the government's regulation of architecture in the name of crime can become

353. See Katyal, supra note 4 , at 2413 (discussing wide-band strategies to minimize substitution effects). 
so pervasive that it upsets other values served by architecture, such as its aesthetic appeal. These complications, though difficult, are not intractable.

Begin by accepting the premise of the first. There are good and bad forms of architectural precaution, and many bad ones may actually increase the crime rate. ${ }^{354}$ Some methods of government regulation, such as the CIS and tort lawsuits, may not mandate a particular form of precaution and thereby run the risk of driving architects to think solely in terms of target hardening. This risk can be minimized through legal rules that require attention to other goals besides the protection of targets, such as natural surveillance. It may also be offset by incorporating specific restrictions on counterproductive designs in the building and housing codes.

These types of land-use decisions will be made at the local level, based on the unique characteristics of a given area. As such, localities will strike different balances on how their regulations are structured. Some regulations may of course culminate in producing some suboptimal architecture, but so too does our current reliance on law enforcement: Because governments concentrate so many resources on law enforcement despite the ability of police to solve only limited amounts of crime (and to prevent even less), private actors are currently driven to use suboptimal forms of architectural protection. And when private actors consider crime prevention in their building, their efforts often express fear rather than control. By contrast, when governments employ, on their own lands, other methods of crime control besides target hardening, they can both inspire private actors and dampen the private incentive to adopt an architecture driven by fear. Government regulation of private building can do even more to avoid the negative externalities created by suboptimal architecture.

A second risk is that by focusing on design, governments will forget about other goals of architecture, such as its aesthetic appeal. Until now we have been considering one facet of architecture-its ability to constrain crime. This facet is only one of the several values architecture serves. The emphasis on crime can, of course, run the risk of obscuring these other values. Such a result would stand the moves made in this Article on their head. To be faithful to architecture, law must first strive to understand these other values and then incorporate them into a crime prevention strategy through design.

The Roman Vitruvius expressed the goals of architecture with a simple formula: "commodity, firmness, delight." ${ }^{355}$ Much contemporary thinking

354. See supra text accompanying notes 171-172 (discussing how items such as cheap iron bars on windows can increase fear and reduce natural surveillance).

355. VITRUVIUS, TEN BOOKS ON ARCHITECTURE 26 (Ingrid D. Rowland trans., Cambridge Univ. Press 1999) (n.d.) ("All these works should be executed so that they exhibit the principles of soundness, utility, and attractiveness."). Vitruvius's words are firmitas, utilitas, and venustas, and were first translated as "firmness, commodity and delight" by Henry Wotten in 1624, and the formulation has persisted, so much so that the three words are engraved today on the Pritzker 
about architecture has underemphasized one aspect of commodity, namely, the ability of design to control crime. But firmness and delight are important values served by architecture, and policy prescriptions that emphasize only one of these values risk the corruption of architecture. ${ }^{356}$ So too, the modern emphasis in architecture schools (and architecture critics) on "delight" also deserves our resistance; aesthetics are simply one goal of architecture, not its end. Architecture thus fundamentally differs from other arts like painting and sculpture; it is always about function. ${ }^{357}$ It is entirely appropriate that law regulate function in circumstances where market failures exist. Indeed, much regulation today-from building codes to zoning decisions-does exactly this. Sometimes these regulations run afoul of other values served by architecture, and these moves are to be resisted, both with respect to crime control and more generally.

When architecture fails to control, or even creates, crime (such as in circumstances where it expresses fear), it is not serving functionality. Theorists of architecture throughout history have emphasized that function is a defining characteristic of architecture, so buildings that do not prevent crime are failing in a fundamental way. Whether the sentiment is expressed in terms of Vitruvius's "commodity" or Heidegger's "dwelling," the control of crime is a critical element of function.

\section{CONCLUSION}

Perhaps because crime is about breaking the law, the natural impulse has been to think about law enforcement as its solution. This Article has urged reconsideration of this impulse. Reconsideration is particularly important in light of advances in architecture that reduce the need to rely on traditional law enforcement. We have not yet broken free of Macaulay's nineteenth-century English assessment that

medal, architecture's most cherished award. See The Hyatt Foundation, About the Bronze Medallion, http://www.pritzkerprize.com/medal.htm (last visited Nov. 29, 2001). Vitruvius's statement has served as the basis for understanding architecture throughout modern history.

356. Karl Llewellyn made a similar point about both architecture and law in his playful essay. See K.N. Llewellyn, On the Good, the True, the Beautiful, in Law, 9 U. CHI. L. REV. 224 (1941). Llewellyn's architecturai moves are an implicit criticism of the view expressed by the ascendant Bauhaus School of architecture and architect Adolph Loos's view of "Ornament as Crime." See Adolf Loos, Ornament and Crime, in PROGRAMS AND MANIFESTOES ON 20TH-CENTURY ARCHITECTURE 19 (Ulrich Conrads ed. \& Michael Bullock trans., MIT Press 1970) (1964).

357. I am not claiming that function is primary, or that "form ever follows function." Louis Henri Sullivan, The Tall Office Building Artistically Considered, LIPPINCOTT's MAG., Mar. 1896, at 403, 408 (making this statement but intending a somewhat different meaning than that now attributed to him). Rather, each of the three values of Vitruvius explains a part of what architecture is about, and legal remedies that lead to the exclusion of any one of these values must be resisted. 
nothing is so ill-made ... as the laws.... Our bridges, our canals, our roads, our modes of communication, fill every stranger with wonder. ... Can there be a stronger contrast than that which exists between the beauty, the completeness, the speed, the precision with which every process is performed in our factories, and the awkwardness, the rudeness, the slowness, the uncertainty of the apparatus by which offences are punished and rights vindicated? $?^{358}$

The fear of anachronistic law has driven cyberlaw theorists to think in terms of architectural solutions, not simply law enforcement. In real space, however, governments have been slow to recognize architectural advances and have instead chosen to throw dollars at hiring additional police and locking up more people with longer sentences for increasingly minor crimes.

This has been an unfortunate choice, for we have seen how architecture works to constrain crime in several ways. Enforcement of rape laws can help avoid some stranger rape; but redesign of fire stairs, public spaces, and exterior lighting can prove far more effective (particularly given the reluctance of some victims to come forward). ${ }^{359}$ Community policing may prevent some windows from being broken, but architects can prevent many more with unbreakable panes and restricted access to window sills. Parent education and gun control might deter some crimes at schools, but changing schools' physical layout to enhance visibility may deter many more. Stepping up law enforcement patrols might foreclose street crimes and drug sales somewhat, but more attention to city street design would reduce crime even further.

The changes to architecture can range from the most fundamental, involving questions of how tall buildings should be and where they must be placed, to the most minute, such as whether door frames should face inward or outward. Some of the most promising solutions concern public lands, such as streets, parks, and public housing. Government attention in this area can instruct architects and stimulate private precautions. Crime impact

358. Lord Macaulay, Speech on the Parliamentary Reform Bill, Delivered in the House of Commons (July 5, 1831), in 1 LORD MACAULAY: SPEECHES AND POEMS 40, $48-49$ (Boston, Houghton, Mifflin \& Co. 1886).

359. Consider the following e-mail 1 received from a young lawyer about a prominent Washington, D.C., law firm:

[Y]ou were supposed to take the (deserted) fire stairs if you were only going one floor but I always took the elevator (and annoyed people) because the fire stairs presented an obvious risk of rape. Just another aspect of the macho firm culture-besides locating the firm in an area where women could not walk safely at night.... I wasn't just completely paranoid, because the stairs meant that several thieves who entered the building stole laptops or wallets, and then had an easy escape .... Fear of rape is a serious problem for women in terms of travelling and even walking around at night, and architecture makes a huge difference.

E-mail to author (Aug. 4, 2001) (on file with author). 
statements, declaratory judgments, and tort lawsuits can further educate architects and the public about using architecture to prevent crime. Other mechanisms, culled from land-use and criminal law, provide additional tools for the government to harness the power of architecture. Some of these methods are not easy to adopt and might not be prudent given their costs, but widespread attention to their drawbacks and benefits can further the dialogue about crime control.

In the end, architecture enables the other constraints on criminal activity to work more effectively. First, architecture can make law enforcement more likely to succeed in its task of catching criminals. Public areas can be made more visible, enabling witnesses and police to observe wrongdoing, and can be configured in ways that make escape more difficult. Second, architecture can modify the social norms of a community. Design can influence the attitudes and beliefs of individuals about a given neighborhood, draw into a community law-abiders with a vested interest in social order, and create conditions conducive to the development of trust among neighbors. Third, architecture can shape preferences away from crime, for example, by influencing the psychology of aggression. Fourth, design can make crime more expensive, thereby creating cost deterrence. When neighborhoods are planned in ways that make surveillance more likely, criminals will incur additional expenditures to carry out their crimes, and such expenditures can deter the criminal act. These constraints on crime-cost deterrence, legal risks, social norms, and individual tastes-are not, of course, influenced by architecture alone, but architecture may be able to alter these variables more easily than the police.

Along the way, this inquiry into architecture yields other interesting results. The focus on natural surveillance suggests, for example, that rent control may decrease crime because it will encourage rootedness. It also generates a new understanding of the expressive function of architecture as it relates to law, providing a helpful lens through which to view everything from the Americans with Disabilities Act to gated communities. Finally, it specifically calls into question the "broken windows" theory of social order policing that has taken hold of America since Wilson and Kelling published their famous article.

Employing architecture will not be easy, nor will it be cheap. But law enforcement is not easy or cheap either. As the costs of design solutions drop while those of policing rise, we cannot afford to be blind to architecture any longer. Bricks may not save us, and mortar will not keep us together, but they can help. 
